San Jose State University

SJSU ScholarWorks

Mineta Transportation Institute Publications

$1-2021$

\title{
Evaluating Financing Mechanisms and Economic Benefits to Fund Grade Separation Projects
}

Shailesh Chandra

California State University, Long Beach

Mehran Rahmani

California State University, Long Beach

Timothy Thai

California State University, Long Beach

Vivek Mishra

California State University, Long Beach

Jacqueline Camacho

California State University, Long Beach

Follow this and additional works at: https://scholarworks.sjsu.edu/mti_publications

Part of the Transportation Commons

\section{Recommended Citation}

Shailesh Chandra, Mehran Rahmani, Timothy Thai, Vivek Mishra, and Jacqueline Camacho. "Evaluating Financing Mechanisms and Economic Benefits to Fund Grade Separation Projects" Mineta Transportation Institute Publications (2021). https://doi.org/10.31979/mti.2020.1926

This Report is brought to you for free and open access by SJSU ScholarWorks. It has been accepted for inclusion in Mineta Transportation Institute Publications by an authorized administrator of SJSU ScholarWorks. For more information, please contact scholarworks@sjsu.edu. 


\section{MINETA TRANSPORTATION INSTITUTE}

Founded in 1991, the Mineta Transportation Institute (MTI), an organized research and training unit in partnership with the Lucas College and Graduate School of Business at San José State University (SJSU), increases mobility for all by improving the safety, efficiency, accessibility, and convenience of our nation's transportation system. Through research, education, workforce development, and technology transfer, we help create a connected world. MTI leads the Mineta Consortium for Transportation Mobility (MCTM) funded by the U.S. Department of Transportation and the California State University Transportation Consortium (CSUTC) funded by the State of California through Senate Bill I.MTI focuses on three primary responsibilities:

\section{Research}

MTI conducts multi-disciplinary research focused on surface transportation that contributes to effective decision making. Research areas include:active transportation; planning and policy; security and counterterrorism; sustainable transportation and land use; transit and passenger rail; transportation engineering; transportation finance; transportation technology; and workforce and labor. MTI research publications undergo expert peer review to ensure the quality of the research.

\section{Education and Workforce Development}

To ensure the efficient movement of people and products, we must prepare a new cohort of transportation professionals who are ready to lead a more diverse, inclusive, and equitable transportation industry. To help achieve this, MTI sponsors a suite of workforce development and education opportunities. The Institute supports educational programs offered by the Lucas Graduate School of Business: a Master of Science in Transportation Management, plus graduate certificates that include High-Speed and Intercity Rail Management and Transportation Security Management. These flexible programs offer live online classes so that working transportation professionals can pursue an advanced degree regardless of their location.

\section{Information and Technology Transfer}

MTI utilizes a diverse array of dissemination methods and media to ensure research results reach those responsible for managing change. These methods include publication, seminars, workshops, websites, social media, webinars, and other technology transfer mechanisms. Additionally, MTI promotes the availability of completed research to professional organizations and works to integrate the research findings into the graduate education program. MTI's extensive collection of transportation-related publications is integrated into San José State University's world-class Martin Luther King, Jr. Library.

\section{Disclaimer}

The contents of this report reflect the views of the authors, who are responsible for the facts and accuracy of the information presented herein. This document is disseminated in the interest of information exchange. MTl's research is funded, partially or entirely, by grants from the U.S. Department of Transportation, the U.S. Department of Homeland Security, the California Department of Transportation, and the California State University Office of the Chancellor, whom assume no liability for the contents or use thereof. This report does not constitute a standard specification, design standard, or regulation. 
REPORT 21-01

\title{
EVALUATING FINANCING MECHANISMS AND ECONOMIC BENEFITS TO FUND GRADE SEPARATION PROJECTS
}

\author{
Shailesh Chandra, PhD \\ Mehran Rahmani, PhD \\ Timothy Thai \\ Vivek Mishra \\ Jaqueline Camacho
}

January 2021

A publication of

Mineta Transportation Institute

Created by Congress in 1991

College of Business

San José State University

San José, CA 95192-0219 


\section{TECHNICAL REPORT DOCUMENTATION PAGE}

1. Report No. 21-01

4. Title and Subtitle

Evaluating Financing Mechanisms and Economic Benefits to Fund Grade

Separation Projects

2. Government Accession No.
3. Recipient's Catalog No.

5. Report Date

January 2021

6. Performing Organization Code

8. Performing Organization Report

CA-MTI-1926

Vivek Mishra

Jaqueline Camacho
Mehran Rahmani, PhD

Timothy Thai

9. Performing Organization Name and Address

Mineta Transportation Institute

College of Business

San José State University

San José, CA 95192-0219

12. Sponsoring Agency Name and Address

State of California SB1 2017/2018

Trustees of the California State

University

Sponsored Programs Administration

401 Golden Shore, 5th Floor

Long Beach, CA 90802
10. Work Unit No.

11. Contract or Grant No. ZSB12017-SJAUX

13. Type of Report and Period Covered Final Report

14. Sponsoring Agency Code

15. Supplemental Notes

DOI: $10.31979 / \mathrm{mti} .2020 .1926$

\section{Abstract}

Investment in transportation infrastructure projects generates benefits, both direct and indirect. While emissions reductions, crash reductions, and travel time savings are prominent direct benefits, there are indirect benefits in the form of real estate enhancements that could pay off debt or loan incurred in the improvement of the infrastructure itself. Studies have shown that improvements associated with rail transportation (such as station upgrades) trigger an increase in the surrounding real estate values, increasing both the opportunity for monetary gains and, ultimately, property tax collections. There is plenty of available guidance that provides blueprints for benefits calculations for operational improvements in rail transportation. However, resources are quite limited in the analysis of benefits that accrue from the separation of railroad at-grade crossings. Understanding the impact of separation in a neighborhood with high employment or population could generate revenues through increased tax collections. In California, the research need is further amplified by a lack of guidance from the California Public Utilities Commission (CPUC) on at-grade crossing for separation based on revenue generated. There is a critical need to understand whether grade separation projects could impact neighboring real estate values that could potentially be used to fund such separations. With COVID-19, as current infrastructure spending in California is experiencing a reboot, an approach more oriented to benefits and costs for railroad at-grade separation should be explored. Thus, this research uses a robust benefits-to-cost analysis (BCA) to probe the economic impacts of railroad at-grade separation projects. The investigation is carried out across twelve railroad-highway atgrade crossings in California. These crossings are located at Francisquito Ave., Willowbrook/Rosa Parks Station, Sassafras St., Palm St., Civic Center Dr., L St., Spring St. (North), J St., E St., H St., Parkmoor West, and Nursery Ave. The authors found that a majority of the selected at-grade crossings analyzed accrue high benefits-to-cost (BC) ratios from travel time savings, safety improvements, emissions reductions, and potential revenue generated if property taxes are collected and used to fund such separation projects. The analysis shows that with the estimated BC ratios, the railroad crossing at Nursery Ave. in Fremont, Palm St. in San Diego, and H St. in Chula Vista could be ideal candidates for separation. The methodology presented in this research could serve as a handy reference for decision-makers selecting one or more at-grade crossings for the separation considering economic outputs and costs.

17. Key Words

Railroad, at-grade crossing, benefits, delay, safety, emissions, crossing

9. Security Classif. (of this report) Unclassified

\section{Distribution Statement}

No restrictions. This document is available to the public through

The National Technical Information Service, Springfield, VA 22161
20. Security Classif. (of this page)

Unclassified
21. No. of Pages

22. Price
80 


\title{
Copyright () 2021 \\ by Mineta Transportation Institute \\ All rights reserved
}

DOI: 10.31979/mti.2020.1926

\author{
Mineta Transportation Institute \\ College of Business \\ San José State University \\ San José, CA 95192-0219
}

Tel: (408) 924-7560

Fax: (408) 924-7565

Email:

transweb.sjsu.edu 


\section{ACKNOWLEDGMENTS}

The research team would like to thank MTI for the funding received to conduct this research. The team would also like to thank Mr. Dominic Spaethling (Vice President at HNTB) and Mr. Eric Peterson for their valuable insights throughout this research.

The authors thank Editing Press, for editorial services, as well as MTI staff, including Executive Director Karen Philbrick, PhD; Deputy Executive Director Hilary Nixon, PhD; Graphic Designer Alverina Eka Weinardy; and Communications and Operations Manager Irma Garcia. 


\section{TABLE OF CONTENTS}

$\begin{array}{lr}\text { Executive Summary } & 1\end{array}$

I. Introduction 3

Current Financing Laws in California $\quad 4$

Examples of Grade Separation Projects 5

$\begin{array}{ll}\text { Economic Models } & 7\end{array}$

$\begin{array}{lr}\text { II. Data Collection } & 9\end{array}$

Property Tax Assessment in California $\quad 13$

Cost Examples 18

$\begin{array}{ll}\text { Grade Separation Challenges } & 20\end{array}$

III. Analyzing Economic Benefits and Costs 22

Input Factors and Basic Assumptions $\quad 25$

Estimating Cost of Separation $\quad 29$

Economic Growth Potential $\quad 30$

IV. Results $\quad 32$

Benefits-to-Cost Evaluation $\quad 33$

Comparison with CPUC-based Grade Separation Approach 36

Underpass/Overpass Recommendation $\quad 37$

$\begin{array}{ll}\text { V. Conclusions } & 38\end{array}$

Appendix A: Google Street View of Candidate At-grade Crossings $\quad 39$

Appendix B: Traffic Delay Formulation 51

Appendix C: Detailed Output of Benefits-to-Cost Analysis 53

Appendix D: Underpass/Overpass Cost Estimation 73

$\begin{array}{ll}\text { Abbreviations and Acronyms } & 74\end{array}$

$\begin{array}{ll}\text { Bibliography } & \mathbf{7 5}\end{array}$

$\begin{array}{ll}\text { About the Authors } & \mathbf{8 0}\end{array}$ 


\section{LIST OF FIGURES}

1. Illustration of Appraised Property Value Calculations 8

2. Spatial Distribution of Railroad At-Grade Crossings in California 10

3. Spatial Representation of Rate of Change in Employment Concentration around California At-Grade Crossings

4. Spatial Representation of Employment around Each At-Grade Crossing in California

5. Spatial Representation of the Concentration of Property Values (year 2020 median home sale price) around At-Grade Crossings in California

6. Spatial Representation of the Concentration of Rate of Change in Property Values around At-Grade Crossings in California

7. Example of Railroad At-Grade Crossing not Suited for Separation

8. Example of One or More Closely Spaced Railroad At-Grade Crossings

9. Flowchart for Determining Benefits-to-Cost Ratio of an At-Grade Crossing

10. Spatial Distribution of AADT and Key At-Grade Crossings Analyzed

11. Grade Separation Costs Variation with AADT 


\section{LIST OF TABLES}

1. Summary of Findings from Example Separation Projects 5

2. Data Summary for Economic Potential Calculation around At-Grade Crossings 11

3. Summary of Incurred Costs for Four Recently Completed Projects in California 19

4. Assumptions for Benefits-to-Cost Analysis 25

5. Inputs and Estimates for Benefits/Savings Calculation 26

6. Details of Analyzed Candidate At-Grade Crossings 28

7. Regression Statistics for the Correlation between AADT and Cost 30

8. Access Improvements of the Crossings After Separation 33

9. Cost Estimation of the Most Expensive Crossing after Separation 33

10. Summary of the Largest Benefits (in dollars) for the Candidate Crossings 35

11. Summary of the Largest Benefits-to-Cost Ratio for Nursery Ave. 35

12. Summary of the Largest Benefit-to-Cost Ratio Considering Only Property Tax Revenue for Nursery Ave.

13. Summary of The Largest Benefits-to-Cost Ratio Considering All Benefits EXCEPT Property Tax Revenue

14. Separation Priority Based on CPUC Priority Index 


\section{EXECUTIVE SUMMARY}

Rail infrastructure improvements have a significant impact on the economic development of a region. These improvements require investments that are often limited. This research aims to evaluate financing mechanisms that can fund separation of railroad-highway atgrade crossings in the State of California. Besides, this research evaluates economic benefits (in terms of potential growth in businesses, employment, real estate values, etc.) surrounding the separated crossing and the costs associated with the separation. The evaluation could help identify key at-grade crossings that would yield high benefits-tocost ratios after separation. These separations are often motivated by the aim of reducing fatalities resulting from vehicle-to-train collisions at the at-grade crossings. Another motivation is saving travel time-thereby increasing motorists' mobility, especially at crossings that experience heavy vehicular traffic.

Based on the data collected from the California Public Utilities Commission (CPUC), there are more than 5,000 railroad at-grade crossings in California. Of these, some 2,000 crossings experience significantly high vehicular traffic and train volumes passing through. Several at-grade crossings have been found to be hot spots for crashes involving trains and pedestrians, bicyclists, or motorists. At-grade railroad crossings are also responsible for the congestion, leading to high traffic delays and pollution and diminishing property values in the neighboring areas.

The methodology laid out in this research is applied across twelve railroad-highway at-grade crossings in California. These crossings are located at Francisquito Ave., Willowbrook/Rosa Parks Station, Sassafras St., Palm St., Civic Center Dr., L St., Spring St. (North), J St., E St., H St., Parkmoor West, and Nursery Ave. After reviewing a list of peer-reviewed publications, the authors of this research effort present brief documentation on key guidance and regulations that aim to generate monetary (and non-monetary) benefits from transportation improvements. The focus is on understanding the benefits and cost implications of railroad at-grade separation projects in California through the lens of existing regulations. The work also describes the interactions between financing mechanisms (such as value capture), as well as the extent of investments needed given the costs of grade separation projects. Therefore, this research is broadly divided into four components. The first part explores existing California laws on financing an infrastructure project (such as a grade separation). The second part documents the usual funding mechanisms used for some examples of grade separation projects. The third part explores economic models that are commonly used in assessing the impacts of railroad projects. The last part presents a spreadsheet-based tool that practitioners can use to quickly compute the benefits-to-cost ratio for separation of more than a dozen railroad at-grade crossings.

The analysis revealed that railroad firms funded a vast majority of grade separation projects completed in the US in recent history. Any benefits such as increases in property values and businesses surrounding a separated railroad crossing are often limited to an area of a quarter-mile radius. 
Data collection was carried out to gather information on factors and variables that can be used to estimate economic benefits after separating an at-grade railroad crossing. In California, the CPUC provides guidance on prioritizing at-grade crossings for separation. However, the CPUC policy for at-grade railroad separation is based on accident rates and congestion but does not factor in the economic viability of the separation; it only considers the daily traffic from the movement of people and goods, project costs, and accident history.

To carry out an economic evaluation, the authors used three data sets (property values, historical rate of increase in property values, and employment concentration and growth) to estimate revenue generated after grade separation. For this purpose, available data from the Center for Economic Studies and Zillow Research were used to draw key inferences.

The authors found that the rates of change in employment, property values, and the total number of jobs are relatively very high surrounding at-grade crossings in the Bay Area and Los Angeles and San Diego.

A basic regression analysis was carried out to determine the correlation between traffic volume passing through an at-grade crossing and the corresponding cost estimated for the separation of the grade crossing.

Adding an economic analysis to the CPUC guidance, the study presented in this research shows that the railroad crossing at Nursery Ave. in Fremont would be ideal for separation. The separation would yield a very high benefits-to-cost ratio. Benefits would include travel time savings, safety improvements, emissions reductions, and so on. A significant property tax revenue could be generated to fund similar railroad at-grade separation projects in California. 


\section{INTRODUCTION}

Rail's impact on economic development is quite well known in transportation research. Studies show that accessibility improvements brought about by rail transportation upgrades trigger increases in real estate values in urban locations (O'Sullivan, 2012). Several other extant studies have also established the price premiums of residential and commercial properties impacted by a short distance to rail transit stations (Hess and Almeida, 2007; Ko and Cao, 2010). Rail transit investments can provide substantial improvements in accessibility for areas with a sparse or insufficient transportation infrastructure compared to huge demand (Cao and Porter-Nelson, 2016). The area around a rail station develops economically to a greater extent than sites far from the station (Giuliano, 2004). However, rail transit investments also usually replace highfrequency bus services, which means accessibility won't increase significantly, and economic impacts might not be noticeable (Rubin et al., 1999).

Research also shows that rail transit investments have more enormous impacts on areas already possessing strong rather than declining growth in the regional economy (Cervero, 2009; Giuliano, 2004). The effects also occur in central business districts or congested areas, which is a common motivation for investments (Giuliano, 2004). Studies have concluded that proximity to rail infrastructure (such as stations) triggers development in an area; however, there is no clarity on whether proximity to rail or proximity to other major intersections or activity areas could have impacted those developments. Therefore, the benefits due to rail investments need to be carefully studied by determining control areas. Other extraneous factors, currently unaccounted for, could play a major role in the growth in businesses and real estate development not attributed solely to rail investment at a target location.

In order to identify zones that could have a high yield from investments after railroad grade separation, the concept of "location quotient" (LQ) can be used (Cao and PorterNelson, 2016). LQ can be adopted to filter and isolate candidate at-grade crossings for evaluating the potential of real estate and business developments around the crossing. LQ is a spatial analysis technique that measures the concentration or dispersion of a given activity across space (Cidell and Alexander, 2009). An LQ value greater than 1 demonstrates concentration, and a value less than 1 demonstrates dispersion. However, determining LQ depends on the availability of real estate data and business surrounding an at-grade crossing, which may not be available.

In this research, an evaluation of the financing mechanisms is carried out to fund separation of a railroad-highway at-grade crossing through assessment of resulting economic benefits (in terms of potential growth in businesses, employment, real estate values, etc.) surrounding the separated crossing. The methodology laid out in this research is carried out across twelve railroad-highway at-grade crossings in California. These crossings are located at Francisquito Ave., Willowbrook/Rosa Parks Station, Sassafras St., Palm St., Civic Center Dr., L St., Spring St. (North), J St., E St., H St., Parkmoor West, and Nursery Ave.

The next section explores existing laws in the State on financing an infrastructure project like grade separation. 


\section{CURRENT FINANCING LAWS IN CALIFORNIA}

There are existing laws in California that provide guidance and regulation for infrastructure project funding, which could be useful for railroad at-grade separation projects as well. The laws have been reviewed with a focus on existing practices that are conducive to supporting value capture techniques of revenue generation. Relevant laws are as follows:

i) Grade Separation Projects (Section 2450-2461) (STREETS AND HIGHWAYS CODE, Chapter 10, Sections 2450 through 2461, 2019) provides guidance on identifying one or more at-grade crossings that could be a priority for separation. The guidance is based on criteria established by the Public Utilities Commission. However, the statutes in this section do not mention potential sources of funding that can be used for grade separation projects.

ii) Tax Increment Financing: California was the first state in the US to implement a very popular tool in 1952 for financing public infrastructure projects and improvements at the district level: tax increment financing, or TIF (Farris and Horbas, 2009). TIF works on a principle similar to value capture techniques used in various parts of the world. The general mechanism of TIF involves creating a defined area and fixing the area's taxable property value. The revenue generated with the subsequent growth in the area's property value is used to finance infrastructure improvements.

Per California law, three major TIF tools can be used for economic development. An agency is entitled to create these tools to finance projects within its jurisdictions. A list of these tools follows (California Association for Local Economic Development, 2019).

a) Enhanced Infrastructure Financing District (EIFD). California Senate Bill 628, signed by Governor Jerry Brown in September 2014, authorizes the legislative body of a city or a county to use TIF to finance various infrastructure improvement projects that lie within its jurisdiction. The financing could be achieved through the establishment of the Enhanced Infrastructure Financing District (EIFD) governed by a public finance authority. Public vote is not required to establish such authorities, and there are no limitations to the geographic extent of the application of the EIFD, which can be used as a process to finance public projects of community-wide significance in a district. Various cities and counties in California have established districts for the purpose of creating EIFDs (EIFD, 2019). EIFDs enable cities to provide a stable source of funding for infrastructure projects and leverage and induce private investments.

b) Community Revitalization and Investment Authority (CRIA). Per the California Government Code 62000 through 62208, a CRIA is entrusted with the revitalization of more impoverished neighborhoods and former military bases. Revitalization means a physical improvement to real property funded by an authority created by a city or a county. The authority adopts a CRIA plan that "may include a provision for the receipt of tax increment funds generated within the area." Public vote is not required for the creation of a CRIA, which focuses on community priorities.

c) Annexation Development Plan (ADP). Per Section 99.3 of Revenue and Tax Code. 
Local agencies such as cities and counties can use TIF to improve infrastructure projects to annex a disadvantaged unincorporated community.

\section{EXAMPLES OF GRADE SEPARATION PROJECTS}

\section{California}

Recently completed grade separation projects in California were reviewed with the aim of documenting funding mechanisms that were (or would be) used to pay for the expenditures involved in these projects. However, available information on funding details for specific projects was found to be limited. Based on the materials retrieved online, none of the projects proposed using value capture or other similar innovative financing methods utilize revenue generated from grade separation projects' economic benefits. In most of these projects, grade separations were completed with funding received from stakeholders. The stakeholders primarily included the railroad companies involved and public agencies offering local, state, or federal funds. Selections from among these recently completed railroad atgrade separation projects in California have been summarized below in Table 1.

Table 1. Summary of Findings from Example Separation Projects

\begin{tabular}{|c|c|c|c|c|c|}
\hline & Project Title & Stakeholder(s) & $\begin{array}{c}\text { Construction } \\
\text { Year }\end{array}$ & $\begin{array}{c}\text { Completion } \\
\text { Year }\end{array}$ & Project Cost/Funding \\
\hline 1 & $\begin{array}{l}\text { Nogales Street Grade } \\
\text { Separation and Roadway } \\
\text { Widening Project }\end{array}$ & $\begin{array}{l}\text { City of Industry } \\
\text { and Los Angeles } \\
\text { County }\end{array}$ & May 2013 & June 2016 & $\begin{array}{l}\text { \$120.8 million } \\
\text { MTA Measure R }\end{array}$ \\
\hline 2 & $\begin{array}{l}\text { Baldwin Avenue Grade } \\
\text { Separation }\end{array}$ & City of El Monte & October 2012 & Spring 2015 & $\$ 70.4$ million \\
\hline 3 & $\begin{array}{l}\text { Puente Avenue } \\
\text { Grade Separation Project }\end{array}$ & $\begin{array}{l}\text { City of Industry } \\
\text { and Los Angeles } \\
\text { County }\end{array}$ & June 2015 & April 2018 & $\$ 97.4$ million \\
\hline 4 & $\begin{array}{l}\text { San Gabriel Trench } \\
\text { Grade Separation Project }\end{array}$ & $\begin{array}{l}\text { City of San } \\
\text { Gabriel }\end{array}$ & Spring 2014 & $\begin{array}{l}\text { September } \\
2018\end{array}$ & $\$ 293.7$ million \\
\hline \multirow[t]{5}{*}{5} & $\begin{array}{l}\text { 25th Avenue Grade } \\
\text { Separation (Caltrain) }\end{array}$ & & & & Funding sources: \\
\hline & & & & & Measure A: $\$ 74$ million \\
\hline & & City of San Mateo & Fall 2017 & Spring 2021 & $\begin{array}{l}\text { City of San Mateo: } \$ 12 \\
\text { million }\end{array}$ \\
\hline & & & & & $\begin{array}{l}\text { State Section 190: } \$ 10 \\
\text { million }\end{array}$ \\
\hline & & & & & $\begin{array}{l}\text { State HSR Prop 1A: } \$ 84 \\
\text { million }\end{array}$ \\
\hline
\end{tabular}

Sources: Alameda Corridor-East Project, 2019; GRADE SEPARATION BayRail Alliance, 2019

Two other specific ongoing grade separation projects in California were also reviewed, and the findings are summarized below.

1. Caltrain corridor grade separation in the City of Palo Alto (White Paper, City of Palo Alto, 2019) 
At present, there is no decision on the type of grade separation (overpass or underpass) needed for the project. There are many potential funding methods to achieve varying levels of funds required for the project, ranging from the local and federal levels. Locals have the option of approving an increase in general taxes or special taxes through bond measures, such as an "ad valorem" property tax, which increases in proportion to the assessed value of a parcel near the improvement site. Thus, the project employs an innovative funding mechanism (similar to value capture techniques).

Other regional funding for the project might come from Santa Clara County's 2016 Measure B, which is expected to provide $\$ 700$ million for the region. State funding may come from the Grade Separation Program administered by the California Public Utilities Commission (CPUC) and Caltrans: this program can typically provide up to $\$ 5$ million per project. As for federal funding, more competitive grants include the Transportation Investment Generating Economic Recovery (TIGER) Grant, which supports innovative projects, or the DOT's Infrastructure for Rebuilding America (INFRA) Grants.

\section{Rengstorff Avenue Grade Separation (Mountain View Voice, 2019)}

The Rengstorff Avenue grade separation cost is $\$ 120$ million, a figure that includes the streets' configuration. The funding would be provided by the Santa Clara Valley Transportation Authority (VTA). The VTA is expected to set aside $\$ 700$ million for grade separation projects, including the Rengstorff Avenue project. The funds are to be provided from the Measure B (2016 Measure B, 2019), which is a half-cent countywide sales tax on each dollar for thirty years. This project is also set to receive funding from the CPUC, which has set aside \$20 million.

\section{Examples of Projects Outside the State of California}

There was minimal information on the details of the mechanisms used to fund railroad grade separation projects in parts of the country outside the State of California. A summary of some key railroad at-grade separation projects is presented below for two key states that have been known to use tax increment financing to fund infrastructure-related improvements.

\section{Illinois}

The authors considered two completed grade separation projects from Chicago, IL. The City of Chicago uses tax increment financing districts to fund a variety of projects, including street improvements and neighborhood redevelopment (Value Capture - FHWA, 2019).

The grade separation projects are managed by the Chicago Region Environmental and Transportation Efficiency Program (CREATE), which is a public-private partnership among the nation's railroads, the State of Illinois, and the City of Chicago. CREATE aims to improve the efficiency of rail infrastructure for commerce and enhance Northeastern, Illinois quality of life. For example, the $\$ 41$ million grade separation project on 25th Avenue \& Union Pacific aims to eliminate the at-grade crossing of 25th Avenue by the Union Pacific Railroad in Bellwood, IL, with an overpass for vehicles using 25th Avenue 
at this location. The grade separation was opened for traffic in 2014 (CREATE, 2019). Another example is the project located on Grand Ave. at the Indiana Harbor Belt (IHB) and CN Franklin Park, IL. The \$45-million project eliminated the at-grade rail-highway crossing by moving Grand Avenue under the Indiana Harbor Belt (IHB) and the CN (Canadian National) tracks (Grand Avenue \& IHB \& CN Grade Separation, 2019). The project was completed in September 2007.

After reviewing the project fact sheets and reports available online, the authors found the financing source of these (and other) projects to be primary partners of the railroad companies, Cook County, and the City of Chicago. However, none of the city's grade separation projects was found to be funded through innovative financing mechanisms. Often it is difficult to determine how far from the separation real estate properties or businesses have received benefits from the grade-separated sites. This also poses a challenge when seeking to implement such financing schemes surrounding the grade separation projects.

\section{Minnesota}

The grade separation project from Minnesota is in the City of Moorhead. The separation project is currently under construction at SE Main Ave./20 St./21 St. and is scheduled for completion in 2020. The grade separation is estimated to cost $\$ 72.5$ million, and the street traffic will pass under new bridges carrying railroad tracks. The potential source of local funding bonds, $80 \%$ of which will be collected through general property tax (City of Moorhead, 2019). Thus, this project is a suitable example of value capture funding for a grade separation project. However, further details on the property tax collection process could not be reported, as limited information was available online for the project.

\section{ECONOMIC MODELS}

This research explores the application of commonly used value capture methods as a financing mechanism. Besides, it is assumed that benefits-to-cost eliminating traffic delays, reduction fatalities, and emissions reductions are indispensable to economic prosperity and growth of the businesses surrounding an at-grade crossing after separation. Thus, economic growth could also give rise to other commonly understood funding mechanisms in practices, as summarized below.

\section{Other Funding Mechanisms}

The extent of available funds drives most large-scale infrastructure projects undertaken by a public authority. Several studies have shown that improvement of rail-related infrastructure (such as station development) has resulted in increases in real estate value and businesses prosper around the improvements (Cao and Porter-Nelson, 2016; Aldrete et al., 2018). However, techniques to exploit all aspects of economic benefits still need to be evaluated and adopted in practice.

Innovative financing mechanisms using a value capture approach, such as the transportation reinvestment zone (TRZ), have been emerging as a very promising revenue generation tool 
for managing large-scale transportation improvement projects in states like Texas (Aldrete et al., 2016). TRZ is a well-known mechanism deployed to estimate the revenue generation potential of a large-scale transportation improvement. Under the principles of a TRZ, a zone is identified which can house a transportation project, and a base year is established. Subsequently, property tax revenue is collected from the zone which would be used to finance a project that lies within the zone (Transportation Reinvestment Zone, 2019).

A railroad grade separation project in a dense urban area is anticipated to have a largescale impact on accessibility, mobility, safety, reliability, and intermodal connectivityespecially for motorists. These impacts become attractive to businesses that open near such improvements, leading to a land value increase, and such projects can be successfully analyzed for revenue potential using the TRZ technique. The technique includes capturing the appraisal value of a property, as noted in Figure 1.
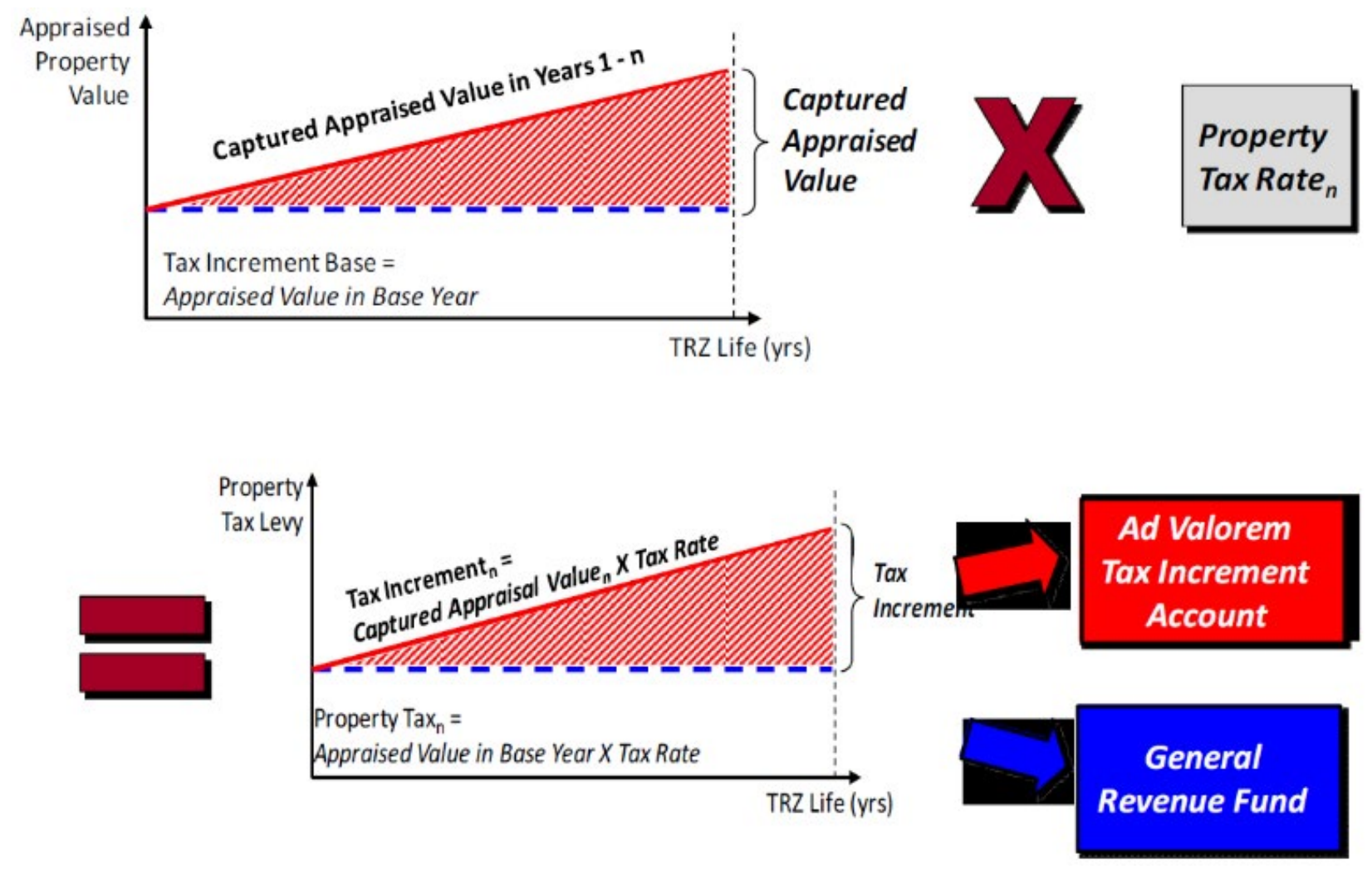

Figure 1. Illustration of Appraised Property Value Calculations

(Source: Vadali et al., 2011)

Research shows that the area around which real estate benefits accrue is limited to a quarter-mile radius around a transportation improvement (Dong, 2016; Vadali et al., 2011). Thus, in this research, a similar assumption is made while accounting for benefits surrounding a grade separation project. 


\section{DATA COLLECTION}

Data collection was carried out to gather information on factors and variables that can be used to estimate economic benefits after grade separation. This research aimed to analyze railroad at-grade crossings in the State of California; similar studies can be conducted for any crossing elsewhere.

Benefits from at-grade separation include revenue generated through value capture. In California, value capture options are being used by the Orange County Transportation Corridor Agencies (TCA) to create funds that have provided seed capital for transportation facilities (Value Capture FHWA, 2019). Therefore, value capture would account for increases in property and businesses' assessed value around the separated at-grade crossing. To achieve the desired level of revenue generated through value capture, the impact on the existing value of real estate properties surrounding the crossings must be known. The procedure is similar to estimating economic value from various other projects that have used value capture or similar techniques in estimating revenues resulting from specific at-grade railroad separation projects (Broadway Grade Separation, 2020; City of Palo Alto, White Paper, 2019).

Statutory guidelines provided by the California Streets and Highways Code requirements Sections 2450 through 2461 prioritize at-grade crossings for separation based on accident rates and congestion (STREETS AND HIGHWAYS CODE, 2019). The code's guidelines do not include economic viability or economic return as value-generated for justifying the separation. Determining value capture generated could be extremely useful in funding such at-grade separation projects. Applications of such value capture techniques have proven to be very promising for other similar large-scale transportation projects elsewhere in the nation (Aldrete et al., 2018).

Three data sets were determined to be necessary for estimating revenue generated from grade separation in California:

1. Property values (land, housing, commercial, etc.) around existing railroad at-grade crossings,

2. The historical rate of increase in property values around the crossing, and

3. Employment concentration and growth around each at-grade crossing. Increase in employment is used as a proxy for business growth in the region surrounding the at-grade crossing.

The spatial locations of existing railroad at-grade crossings are obtained from the California Public Utilities Commission (CPUC) and the Caltrans GIS library (Caltrans, 2020). In 2020, there are more than 14,000 at-grade rail crossings in California. Out of more than 14,000 crossings, only 4,703 crossings are in locations for which Zillow had information on the property values. These crossings are also surrounded by high employment concentration and growth. The spatial distribution of these at-grade crossings is shown in the map of Figure 2. Then, Table 2 provides a summary of data identified for use in revenue estimation. 


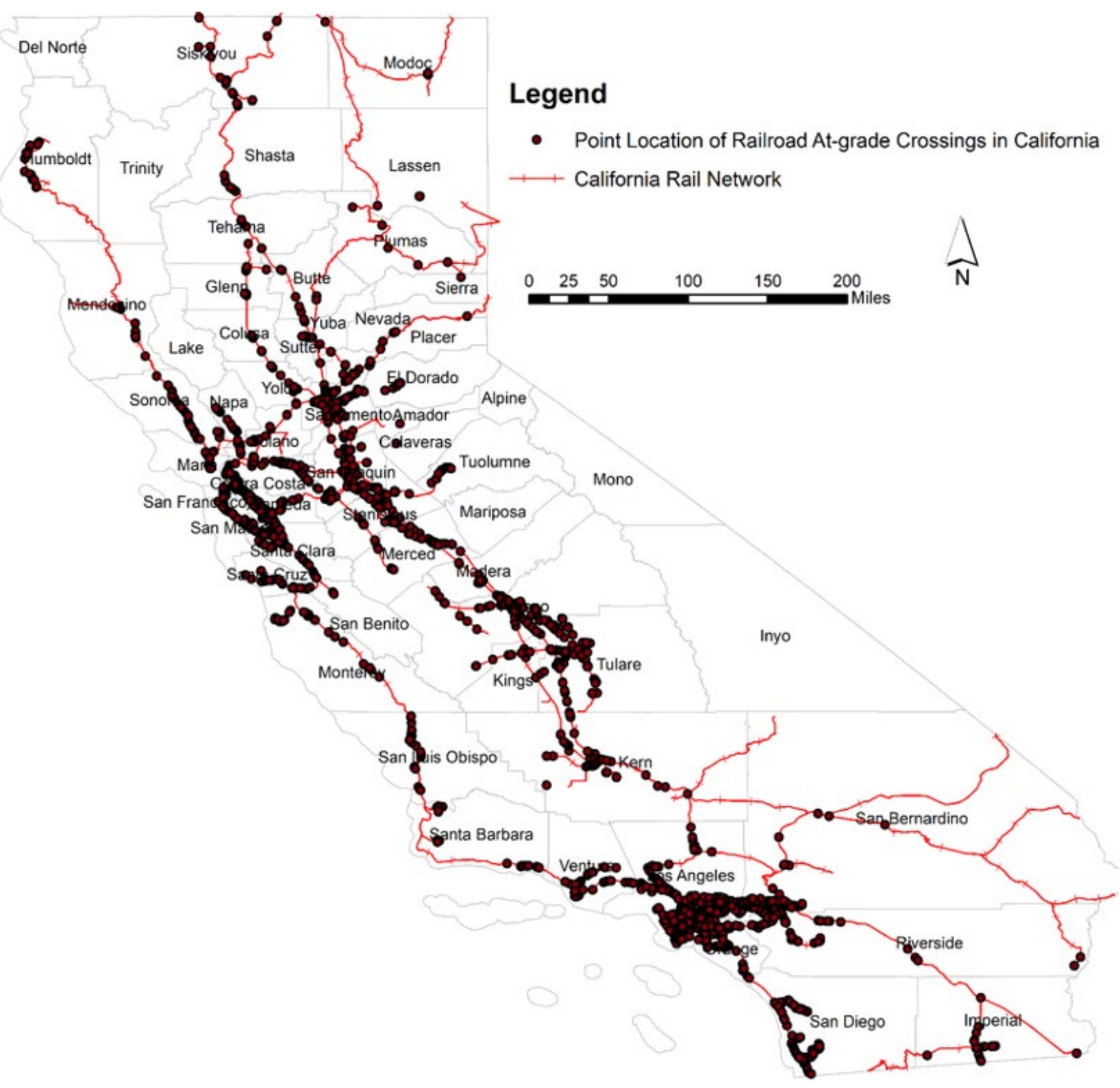

Figure 2. Spatial Distribution of Railroad At-Grade Crossings in California 
Table 2. Data Summary for Economic Potential Calculation around At-Grade Crossings

\begin{tabular}{l} 
Map Content \\
\hline $1 \quad$ Rate of change in employment was \\
used as a proxy for business growth \\
in the vicinity of the at-grade crossing. \\
Level of employment can also be \\
used as an indicator of travel activity \\
and movement of people-thus \\
representing congestion around the \\
business establishments and the \\
crossing. \\
Note: The rate was used to identify \\
those at-grade crossings which had \\
the potential for sustained business \\
growth surrounding them. The higher \\
the rate of increase, the more likely the \\
corresponding at-grade crossing is to \\
be selected for separation.
\end{tabular}

2 Year 2020 employment (jobs) surrounding at-grade crossing (for various buffer sizes).

Note: The extent of employment increase was used as a proxy for increase in businesses surrounding an at-grade crossing. Note that the rate was used to determine business growth areas around the crossing.

3 Property values are represented through median home sale price for the year 2020 and surrounding at-grade crossing. Homes that were within the buffer radius of 0.25 miles were used for at-grade crossing.
Methods

Rate obtained using the base year employment data from 2012 through 2017; data extrapolated for year 2020 .

Source: LEHD, 2020

Data for the year 2020 obtained via extrapolation of data from 2013 through 2017.

The property values were available at the lowest spatial resolution of zip codes for the year 2020 .

Data source: Housing data from Zillow Research (2020)
Rate was calculated for the latest five years' employment data from 2012-2017. The year 2012 was used as the cut-off to avoid any biases in employment numbers that might have occurred due to recession periods in the years 2008-2009.

The latest six years' data from 2013 through 2017 were used in the extrapolation.

Property values surrounding an atgrade crossing were approximated from its zip code property values. The values were calculated primarily for those homes that were within a quar mile buffer surrounding an at-grade crossing.

\section{Other Observations}

Rate of change in employment is relatively very high surrounding at-grade crossings in the Bay Area counties and in counties of Los Angeles and San Diego compared to most other California counties.

Reference: Figure 3

Total number of jobs is relatively higher surrounding at-grade crossings in the Bay Area counties and in counties of Los Angeles and San Diego compared to most other California counties.

Reference: Figure 4

Property values are relatively high surrounding at-grade crossings in the Bay Area counties and in counties of Los Angeles and San Diego compared to most other California counties.

Reference: Figure 5 


\section{Table 2, continued}

\begin{tabular}{|c|c|c|c|c|}
\hline & Map Content & Data Description & Methods & Other Observations \\
\hline 4 & $\begin{array}{l}\text { Rate of change in property values } \\
\text { surrounding at-grade crossing (for } \\
\text { various buffer sizes) }\end{array}$ & $\begin{array}{l}\text { Data source: Housing data from Zillow } \\
\text { Research }\end{array}$ & $\begin{array}{l}\text { The average property value } \\
\text { surrounding an at-grade crossing was } \\
\text { assumed to be equal to the average } \\
\text { value of a property in a zip code in } \\
\text { which the crossing was located. }\end{array}$ & $\begin{array}{l}\text { The rate of change in property values } \\
\text { is relatively very high surrounding } \\
\text { at-grade crossings in the Bay Area } \\
\text { counties and in counties of Los Angeles } \\
\text { and San Diego compared to most other } \\
\text { California counties. }\end{array}$ \\
\hline
\end{tabular}

Reference: Figure 6 


\section{PROPERTY TAX ASSESSMENT IN CALIFORNIA}

The property tax for housing in California is less than $1 \%$, and the increase in the tax is capped at $2 \%$. However, this percentage can change for particular purposes: for example, in our case, when the area or community surrounding a crossing receives benefits due to grade separation. The property tax rate can vary such that the debt incurred in grade separation by the city is paid off on time, usually 30 years (California Property Tax Calculator, 2020). 

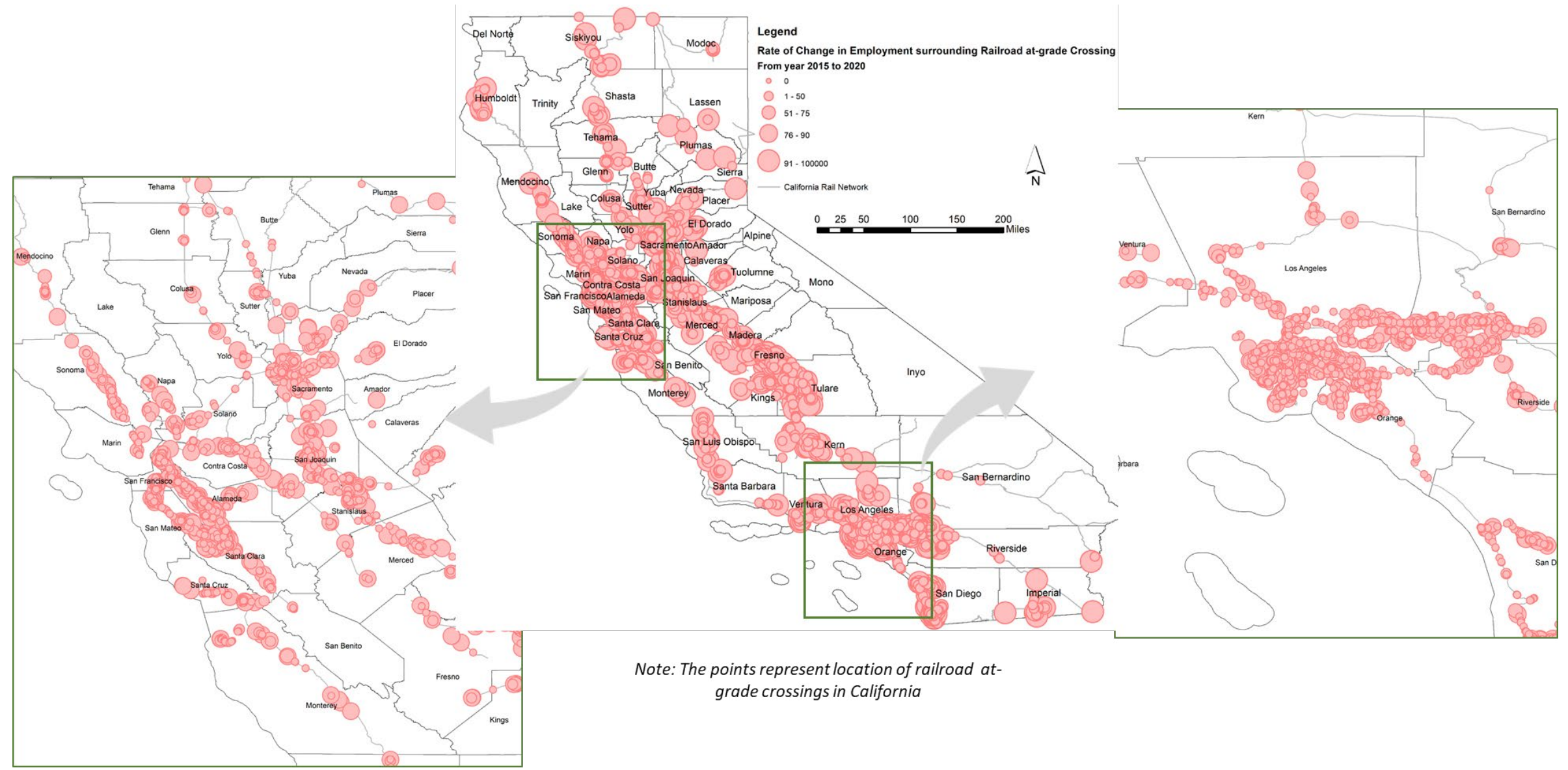

Note: The points represent location of railroad atgrade crossings in California

Figure 3. Spatial Representation of Rate of Change in Employment Concentration around California At-Grade Crossings (Data Source: LEHD, 2020) 

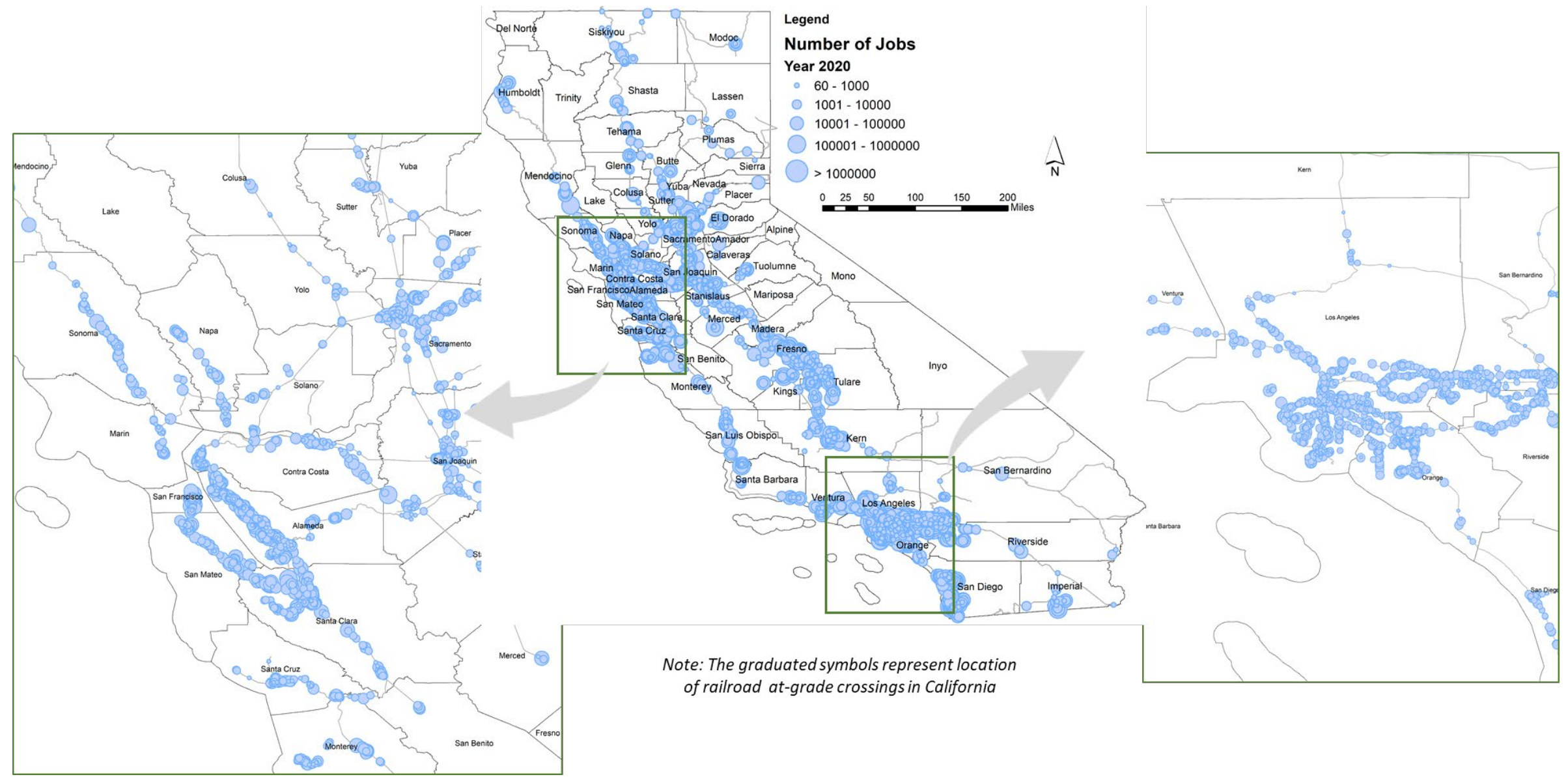

Figure 4. Spatial Representation of Employment around Each At-Grade Crossing in California (Data Source: LEHD, 2020) 


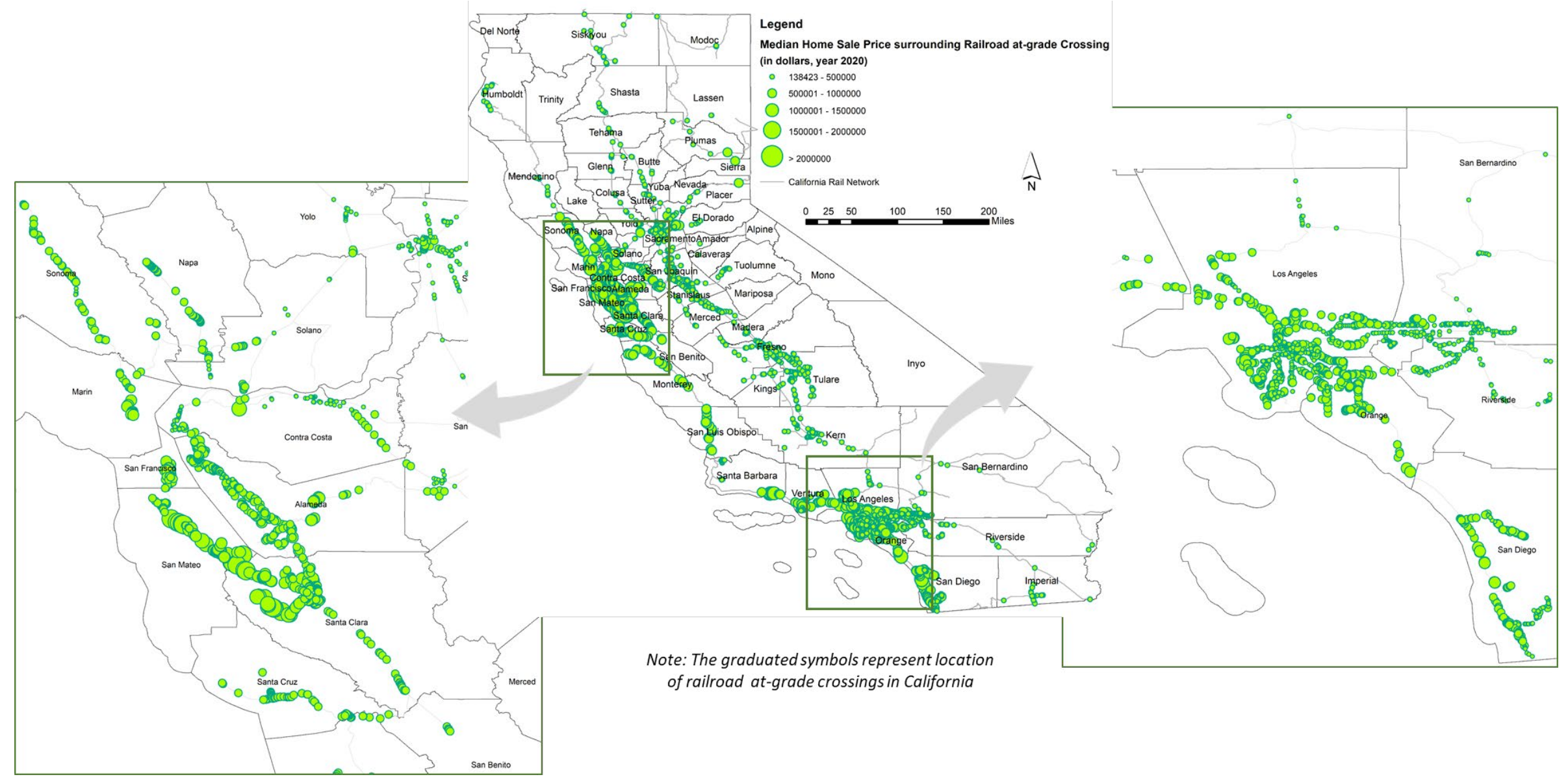

Figure 5. Spatial Representation of the Concentration of Property Values (year 2020 median home sale price) around At-Grade Crossings in California

(Data Source: LEHD, 2020. Property values calculated based on year 2020 median home sale price.) 


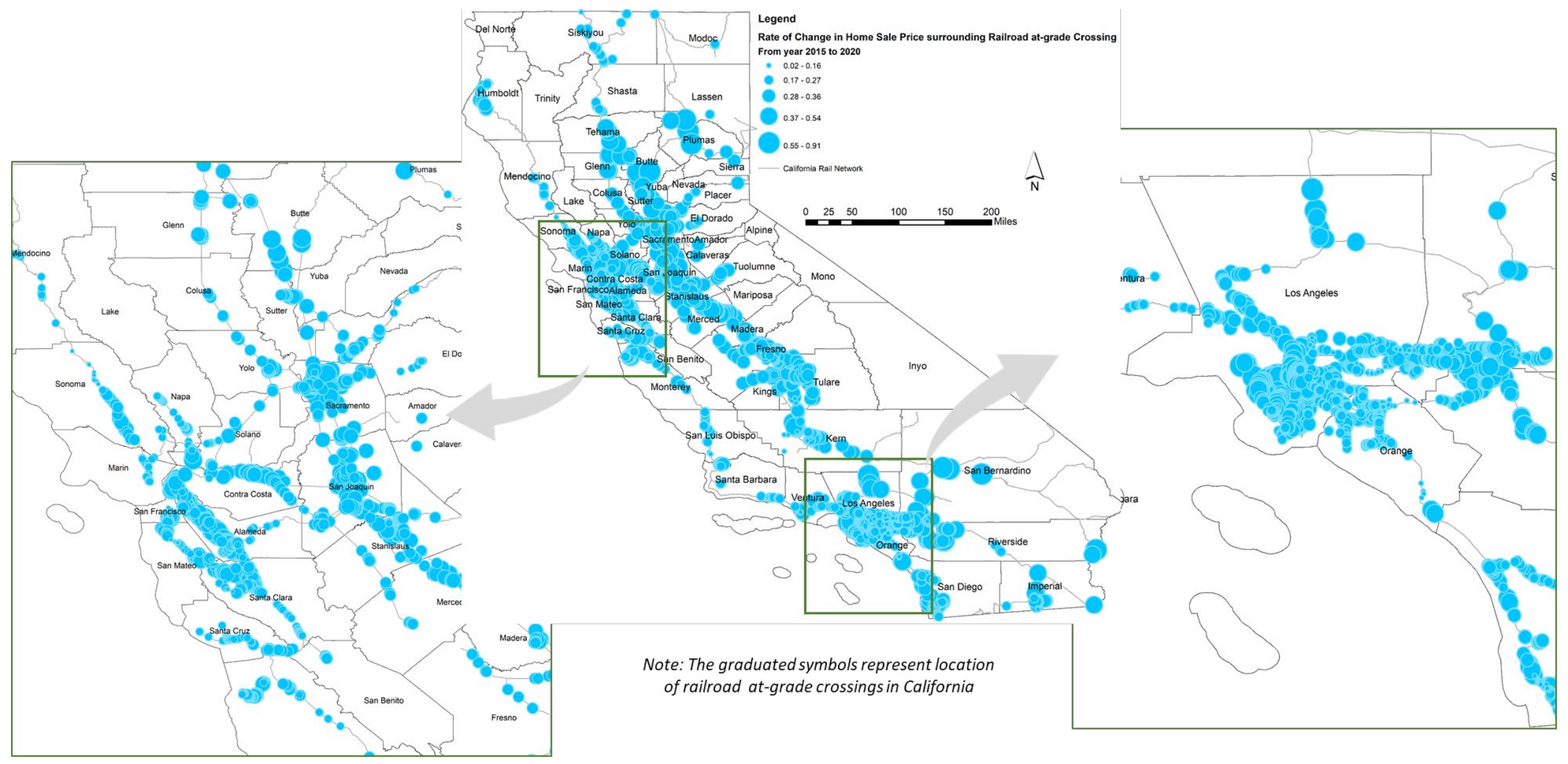

Figure 6. Spatial Representation of the Concentration of Rate of Change in Property Values around At-Grade Crossings in California

(Data Source: LEHD, 2020. Property values calculated based on year 2020 median home sale price.) 


\section{COST EXAMPLES}

An at-grade railroad crossing can be separated either by constructing a railroad bridge that overpasses the roadway or by constructing an overpass bridge over the at-grade crossing or trenched rail tracks. In both cases, one or more bridges must be constructed at the crossing. The roadway at the crossing must be reconstructed-a task that includes lowering the roadway or the rail tracks at the crossing and constructing ramps and loop connectors. In this section, a lump-sum cost estimate for separating a rail crossing has been provided. For this purpose, a detailed investigation of costs associated with the construction of four recently separated rail crossings were performed. Table 3 presents a summary of key information on constructed bridges and roadways as well as their construction costs. The last column in Table 3 takes into account the size of construction for each project by normalizing the total cost by the net area of the constructed bridge. The results suggest that today's estimated cost for separating a rail crossing is on average $\$ 10,000$ per square foot of construction in California. 
Table 3. Summary of Incurred Costs for Four Recently Completed Projects in California

\begin{tabular}{|c|c|c|c|c|c|}
\hline & Project Title & Project City, County & $\begin{array}{c}\text { Project Description (Type of Separations, Sizes, and } \\
\text { Construction Materials) }\end{array}$ & Total Project Cost & $\begin{array}{l}\text { Cost per Square } \\
\text { Foot }\end{array}$ \\
\hline 1 & $\begin{array}{l}\text { Nogales Street Grade } \\
\text { Separation and } \\
\text { Roadway Widening } \\
\text { Project }\end{array}$ & $\begin{array}{l}\text { City of Industry, } \\
\text { Los Angeles County }\end{array}$ & $\begin{array}{l}\text { The project comprises a railroad bridge accommodating two rail } \\
\text { tracks overpassing the four-lane Nogales Street. } \\
\text { The bridge consists of two spans with overall dimensions of } 40 \\
\text { feet by } 120 \text { feet. } \\
\text { The bridge construction material and system are a precast } \\
\text { concrete box girder deck mounted on four concrete piers. }\end{array}$ & $\begin{array}{l}\text { \$46.5 million } \\
\text { Completed in } 2016\end{array}$ & $\begin{array}{l}\text { Estimated } \\
\$ 9,500 / \mathrm{ft}^{2}\end{array}$ \\
\hline 2 & $\begin{array}{l}\text { Baldwin Avenue } \\
\text { Grade Separation }\end{array}$ & $\begin{array}{l}\text { City of El Monte, } \\
\text { Los Angeles County }\end{array}$ & $\begin{array}{l}\text { The project comprises a railroad bridge accommodating two rail } \\
\text { tracks overpassing the four-lane Baldwin Avenue. } \\
\text { The bridge consists of two spans with overall bridge dimensions } \\
\text { of } 40 \text { feet by } 110 \text { feet. } \\
\text { The bridge construction materials and system are pre-stressed } \\
\text { concrete girders mounted on a cap beam and three concrete } \\
\text { piers. }\end{array}$ & $\begin{array}{l}\text { \$23 million } \\
\text { Completed in } 2015\end{array}$ & $\begin{array}{l}\text { Estimated } \\
\$ 5,200 / \mathrm{ft}^{2}\end{array}$ \\
\hline 3 & $\begin{array}{l}\text { 25th, 28th, and } \\
\text { 31st Avenue Grade } \\
\text { Separation (25th } \\
\text { Avenue Grade } \\
\text { Separation Caltrain, } \\
\text { 2019) }\end{array}$ & $\begin{array}{l}\text { City of San Mateo, } \\
\text { San Mateo County }\end{array}$ & $\begin{array}{l}\text { The project comprises three separate railroad bridges, each } \\
\text { accommodating two rail tracks; the bridges respectively pass over } \\
\text { the four-lane } 25 \text { th, } 28 \text { th, and } 31 \text { st Avenues in San Mateo. } \\
\text { The three bridges are mostly identical in size and construction } \\
\text { materials. The bridges each consist of two spans, with overall } \\
\text { bridge dimensions of } 50 \text { feet by } 110 \text { feet. } \\
\text { The bridges at } 25 \text { th and } 28 \text { th Avenues are constructed using } \\
\text { concrete girders and concrete columns, while the bridge at } 31 \text { st } \\
\text { Avenue is made of steel girders and concrete piers. }\end{array}$ & $\begin{array}{l}\$ 165.3 \text { million for all } \\
\text { three bridges } \\
\text { To be completed in } \\
2021\end{array}$ & $\begin{array}{l}\text { Estimated } \\
\$ 10,000 / \mathrm{ft}^{2}\end{array}$ \\
\hline 4 & $\begin{array}{l}\text { San Gabriel Trench } \\
\text { Grade Separation } \\
\text { Project }\end{array}$ & $\begin{array}{l}\text { City of San Gabriel, } \\
\text { Los Angeles County }\end{array}$ & $\begin{array}{l}\text { The unique project comprises } 1.4 \text { miles of railroad tracks lowered } \\
\text { into a trench. The trench is } 65 \text { feet wide and } 30 \text { feet deep, } \\
\text { facilitating separation of four at-grade roadway crossings at } \\
\text { Ramona Street, Mission Road, Del Mar Avenue, and San Gabriel } \\
\text { Blvd. Overhead bridges were constructed using pre-stressed } \\
\text { girders. The bridges are all } 65 \text { feet long, but their widths vary from } \\
75 \text { feet to } 110 \text { feet. }\end{array}$ & $\begin{array}{l}\text { \$172.6 million } \\
\text { Completed in } 2018\end{array}$ & $\begin{array}{l}\text { Estimated } \\
\$ 7400 / \mathrm{ft}^{2}\end{array}$ \\
\hline
\end{tabular}

It is noted that the design codes and regulations mandated by the jurisdiction where the crossing is located can govern the type of separation, the design goals, and the choice of construction materials. Besides, the labor and materials supply varies across jurisdictions in California. These factors can affect the total cost of a rail crossing separation. 


\section{GRADE SEPARATION CHALLENGES}

Not all at-grade crossings seem feasible for separation due to practical reasons. The following two situations were noted for at-grade crossings that need to be eliminated from the pool of crossings in California to be considered for separation.

1. Isolated at-grade crossing located on a low-volume road. At-grade crossings in the vicinity of an already separated crossing also showed very high employment rates. Most of these similar at-grade crossings were present on zero to a very low traffic volume roads (see the red dot in Figure 7 ). It would not be practical to consider such at-grade crossings for analysis and hence for separation. Therefore, these and other similar at-grade crossings would be dropped out from consideration as potential candidates for separation.

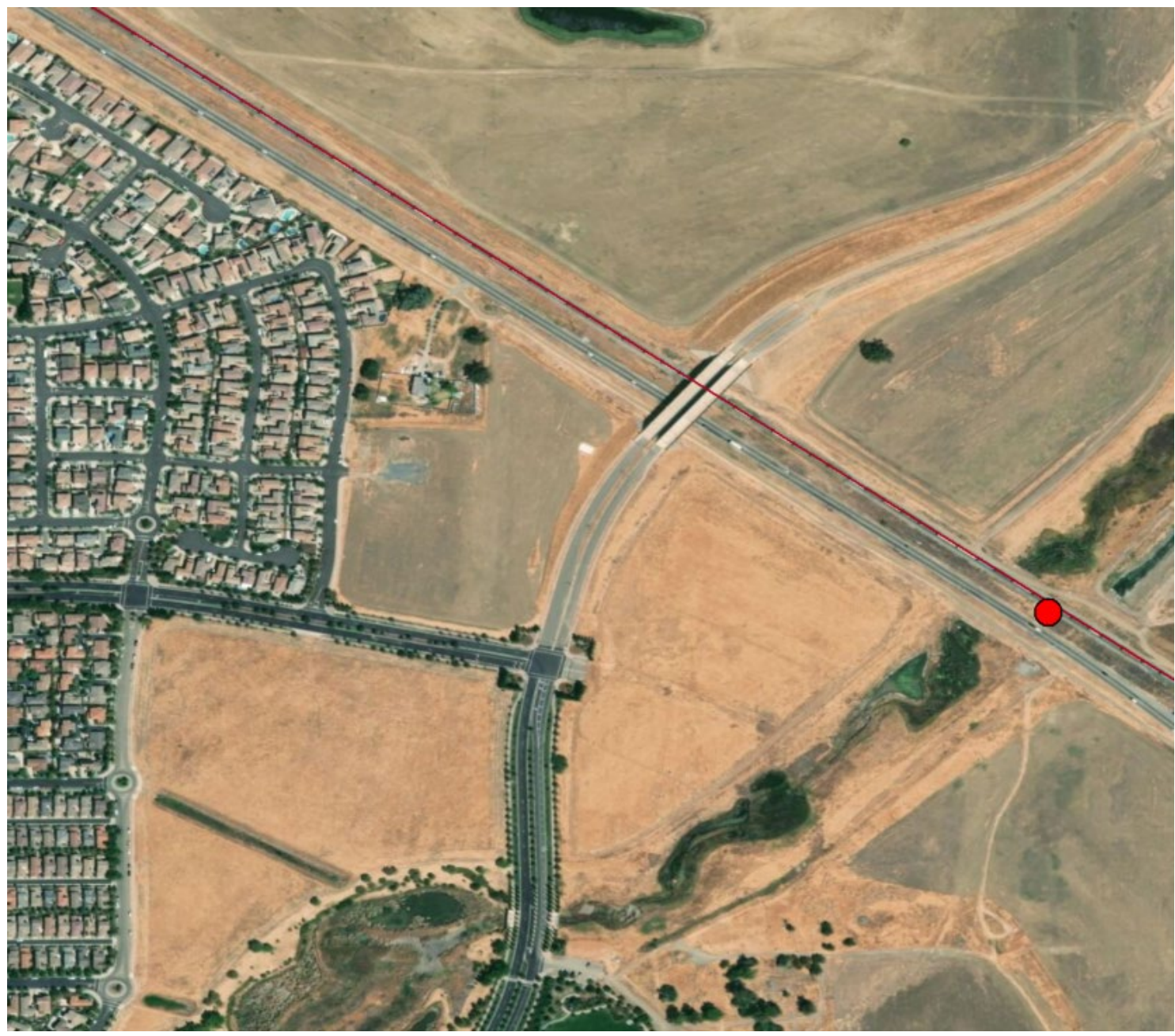

Figure 7. Example of Railroad At-Grade Crossing not Suited for Separation

2. Multiple closely spaced at-grade crossings. The map in Figure 8 shows several closely spaced at-grade crossings within a few hundred feet of each other. Proximity makes these crossings difficult and economically challenging to separate. Separating one of these at-grade crossings as an overpass or underpass may make the construction 
and realignment of the railroad and street crossings unfeasible. Therefore, these and similar at-grade crossings were dropped out from consideration as potential candidates for separation.

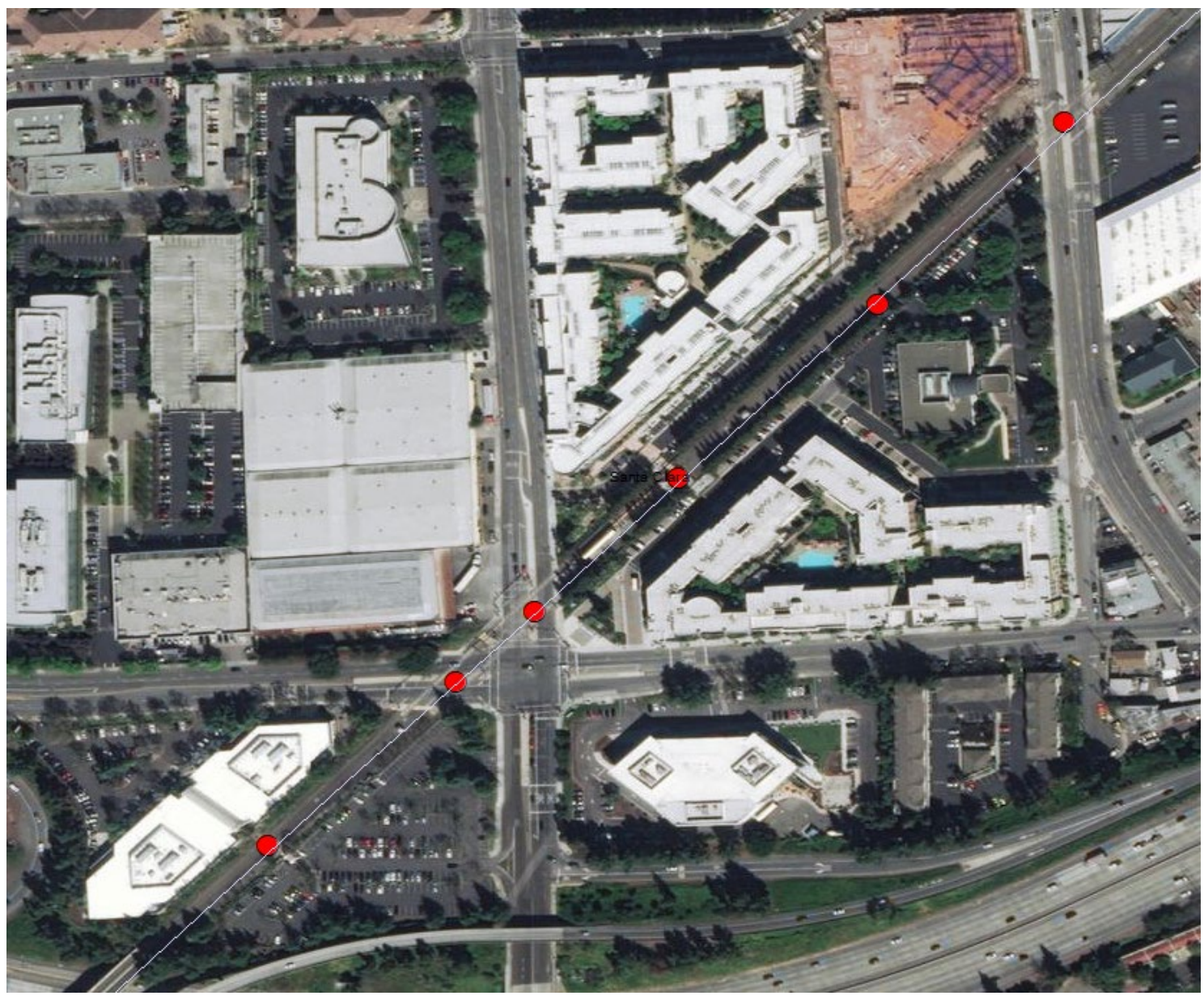

Figure 8. Example of One or More Closely Spaced Railroad At-Grade Crossings

Therefore, efforts were made to focus only on those feasible at-grade crossings in California that would be suitable for separation and had the potential to yield the largest benefits-tocost ratio. 


\section{ANALYZING ECONOMIC BENEFITS AND COSTS}

With reference to Section 190 of the CPUC's Grade Separation Program, in California (CPUC, 2020), the formula used for determining an at-grade crossing for separation uses a Priority Index Number, which is expressed as

$$
P=\frac{V^{*}\left(T+0.1^{*} L R T\right) *(A H+1)}{C}+S C F
$$

where

$$
\begin{aligned}
& \text { P = Priority Index Number, } \\
& \text { V = Average Daily Vehicle Traffic, } \\
& \text { T = Average Daily Freight/Commuter Train Traffic, } \\
& \text { LRT = Average Daily Light Rail Train Traffic, } \\
& \text { C = Project Cost Share to be Allocated from Grade Separation Fund, } \\
& \text { AH = Accident History (number of accidents at the crossing), and } \\
& \text { SCF = Special Conditions Factor (CPUC, 2020). }
\end{aligned}
$$

However, the Priority Index Number in Eq. (1) does not consider monetary benefits (or associated costs) involved in the separation of an at-grade crossing, making it challenging to identify an appropriate at-grade crossing needing separation yielding a high benefits-tocost ratio. The procedure consists of first determining the traffic volume passing through an at-grade crossing and then using the information on train speeds and their frequency to estimate vehicular traffic delays or wait times at the crossing. Pertinent data on traffic volume was assumed to be the annual average daily traffic (AADT) along with the number of trains and their speeds and predicted accidents were obtained from the Federal Railroad Administration (FRA, 2020). The spatial locations of the crossings in California were obtained from the CPUC website.

The flowchart in Figure 9 presents the procedure for identifying the at-grade crossing that would yield the largest benefits-to-cost ratio after separation. An analysis of benefits and costs for both undiscounted and discounted scenarios is presented.

In the flowchart of Figure 9, step A involves the choice of an appropriate buffer distance around a candidate at-grade crossing. To include those properties that will potentially benefit after the separation, a quarter-mile buffer radius has been chosen. Benefits could consist of revenue generated through property taxes that can contribute to paying off the cost involved in the separation of a candidate crossing. Studies show that a buffer distance of a quarter-mile, as used in this research, is ideal for assessing such benefits accrued from a transportation improvement.

Step B (Figure 9) denotes the economic growth potential of an at-grade crossing that exists before its separation. The economic potential of a transportation infrastructure 
element is defined by the improvement's ability to trigger economic activities (such as employment increase, business growth, etc.) in the surrounding region after implementation. Economic potential can be easily formulated given data on economic factors such as job concentrations and mobility (travel time changes) after the improvements are available. In the context of railroad improvements, economic potential can be used as a first-hand measure to estimate the relative magnitude of economic benefits of separation of an atgrade crossing with respect to other candidates. The concept of economic potential and its application is discussed in further detail later in this report and is based on the theory of access improvement brought about by the separation.

Step C in Figure 9 depicts a regression model's development to estimate costs that could be incurred in the separation of an at-grade crossing. Data from more than sixty railroad at-grade crossings were analyzed to determine the relationship between costs and the traffic volume information. 


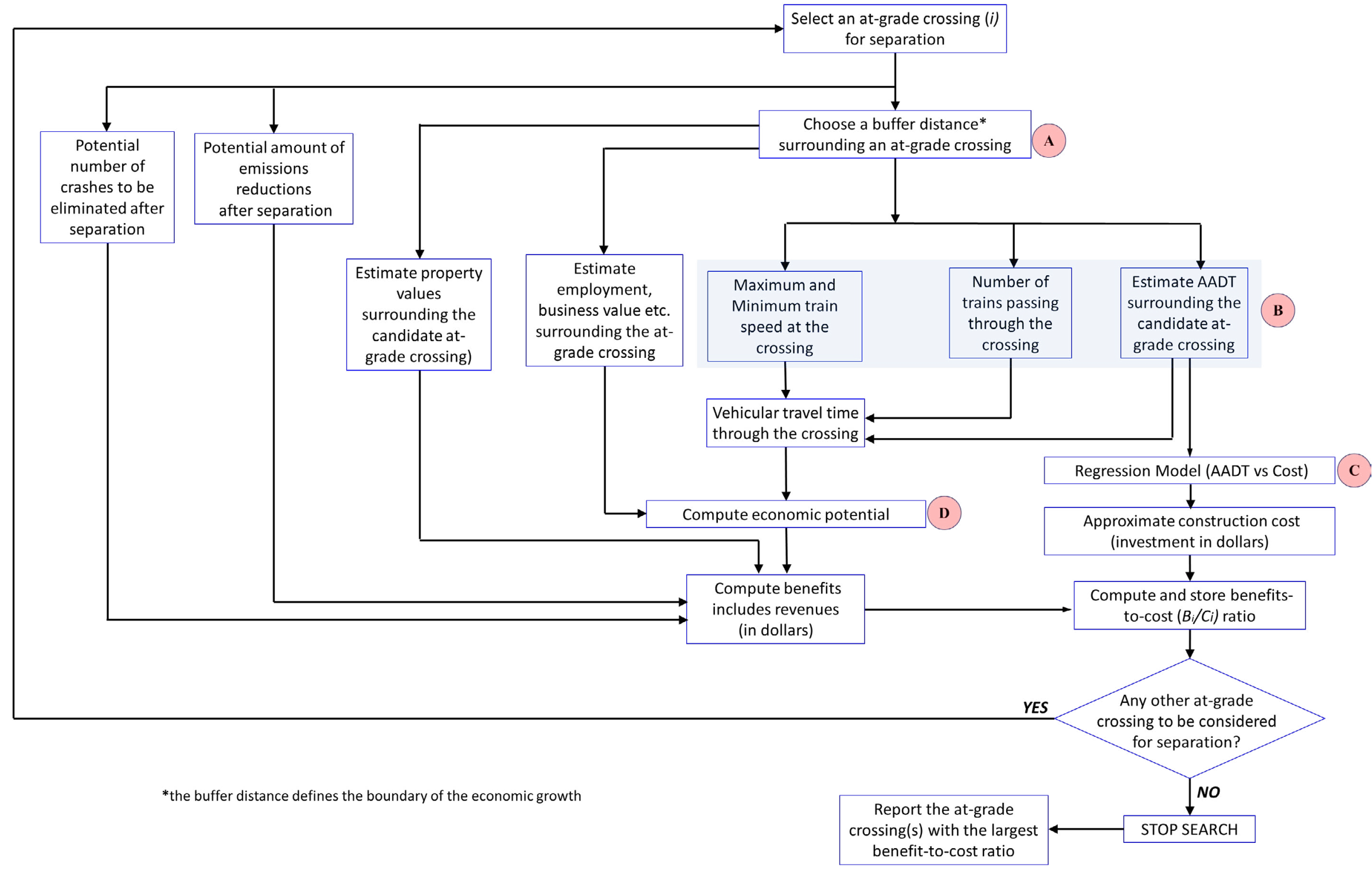

Figure 9. Flowchart for Determining Benefits-to-Cost Ratio of an At-Grade Crossing 


\section{INPUT FACTORS AND BASIC ASSUMPTIONS}

A list of inputs that were used in estimating the benefits resulting from the separation has been summarized in Tables 4 and 5. All monetary benefits/savings calculations are converted into present value dollars (i.e., the year 2020 USD). The analysis has been performed for 20 years (i.e., through 2040). Three cases have been considered for the benefits-to-cost evaluation: undiscounted discounted at $3 \%$ and discounted at $7 \%$.

Table 4 provides information on basic assumptions for estimating the benefits and costs for a defined analysis period.

Table 5 presents inputs needed to estimate the benefits of safety improvements, travel time savings, and emissions reductions. Other benefits (savings in vehicle operating costs, decreased pavement damage, etc.) are not as significant as any of the three benefit categories considered in this study (MDT, 2016). Moreover, this study includes revenue generated through property tax as an additional benefit to support the determination of the most suitable at-grade crossing for separation.

Table 4. Assumptions for Benefits-to-Cost Analysis

\begin{tabular}{lll}
\hline \multicolumn{1}{c}{ Inputs } & \multicolumn{1}{c}{ Value } & \multicolumn{1}{c}{ Reference(s) } \\
\hline Base year & 2020 & Assumption \\
Project start year & 2021 & Assumption \\
First year of benefits & 2023 & Assumption \\
Period of analysis & 20 years & Assumption (through 2040) \\
Discount rate & $7 \%$ & USDOT Guidance (2018) \\
Discount rate (sensitivity) & $3 \%$ & USDOT Guidance (2018) \\
\hline
\end{tabular}


Table 5. Inputs and Estimates for Benefits/Savings Calculation

\begin{tabular}{|c|c|c|c|c|}
\hline \multicolumn{2}{|c|}{$\begin{array}{c}\text { Benefit Type/Cost Saving } \\
\text { Type }\end{array}$} & \multirow{2}{*}{$\begin{array}{c}\text { Units } \\
2020 \text { USD }\end{array}$} & \multirow{2}{*}{$\begin{array}{c}\text { Value } \\
\$ 10.25 \text { million }\end{array}$} & \multirow{3}{*}{$\begin{array}{l}\text { Reference(s) for Equivalent Dollar } \\
\text { Value Calculation } \\
\text { - } 2016 \text { Revised Value of a Statistical } \\
\text { Life Guidance (USDOT, 2020). } \\
\text { - The US inflation for the year 2020 } \\
\text { (from 2016) is 6.8\% (US Inflation } \\
\text { Calculator, 2020) }\end{array}$} \\
\hline Safety & $\begin{array}{l}\text { Value of a } \\
\text { statistical } \\
\text { life (due to } \\
\text { fatality) }\end{array}$ & & & \\
\hline & Cost of injury & 2020 USD & \$1.07 million & \\
\hline $\begin{array}{l}\text { Travel time } \\
\text { savings }\end{array}$ & $\begin{array}{l}\text { Value of time } \\
\text { for automobile }\end{array}$ & $\begin{array}{l}2020 \text { USD / } \\
\mathrm{hr}\end{array}$ & $\$ 14.93$ & $\begin{array}{l}\text { - USDOT Revised Departmental } \\
\text { Guidance: Valuation of Travel Time } \\
\text { in Economic Analysis (USDOT, } \\
2016 \text { ) } \\
\text { - Inflation rate from } 2015 \text { to } 2020= \\
8.2 \%\end{array}$ \\
\hline \multirow{6}{*}{$\begin{array}{l}\text { Environmental } \\
\text { benefits: } \\
\text { emissions }\end{array}$} & $\begin{array}{l}\text { VOC (volatile } \\
\text { organic }\end{array}$ & $\begin{array}{l}\text { grams per } \\
\text { minute }\end{array}$ & 0.0447 & \multirow{6}{*}{$\begin{array}{l}\text { - GradeDec. Net Reference Manual } \\
\text { - Equation } 29 \text { Average Daily } \\
\text { Emissions at Crossing by } \\
\text { Vehicle Type } \\
\text { - Equation } 30 \text { Environmental } \\
\text { Benefits (for each year and } \\
\text { crossing) }\end{array}$} \\
\hline & compounds) & $\begin{array}{l}2020 \text { USD / } \\
\text { ton }\end{array}$ & $\$ 1,990$ & \\
\hline & $\mathrm{NO}_{x}$ & $\begin{array}{l}\text { grams per } \\
\text { minute }\end{array}$ & 0.0586 & \\
\hline & & $\begin{array}{l}2020 \text { USD / } \\
\text { ton }\end{array}$ & $\$ 7,841.65$ & \\
\hline & $\mathrm{CO}_{2}$ & $\begin{array}{l}\text { grams per } \\
\text { minute }\end{array}$ & 31.065 & \\
\hline & & $\begin{array}{l}2020 \text { USD / } \\
\text { ton }\end{array}$ & $\$ 46.78$ & \\
\hline \multicolumn{2}{|c|}{$\begin{array}{l}\text { Property taxes, as alternative } \\
\text { financing mechanism through } \\
\text { Enhanced Infrastructure } \\
\text { Financing Districts (EIFDs) }\end{array}$} & 2020 USD & $\begin{array}{l}\text { County } \\
\text { median } \\
\text { property taxes }\end{array}$ & $\begin{array}{l}\text { - California Property Taxes } 2020 \text { ( } \\
\text {, 2020) }\end{array}$ \\
\hline
\end{tabular}

Based on the train speeds and frequency at a crossing, the authors calculated vehicular delays at at-grade crossings (Appendix $B$ provides a detailed analysis of the traffic delay). Traffic delays for the vehicles at an at-grade crossing are calculated based on the formulation presented in the Northern Rail Extension Draft Environmental Impact Statement (SURFACE TRANSPORTATION BOARD, 2020) and using models from queuing theory: Details of the formulation, and a detailed analysis of the traffic delay, can be found in Appendix B.

Twelve candidate at-grade crossings were selected as examples to demonstrate the application of the methodology outlined in the flowchart of Figure 9. The spatial locations (along with Google Street View images) of these twelve locations have been provided in Appendix A. Data in Table 6 present the details of the selected twelve candidate at-grade crossings for benefits-to-cost analysis. 


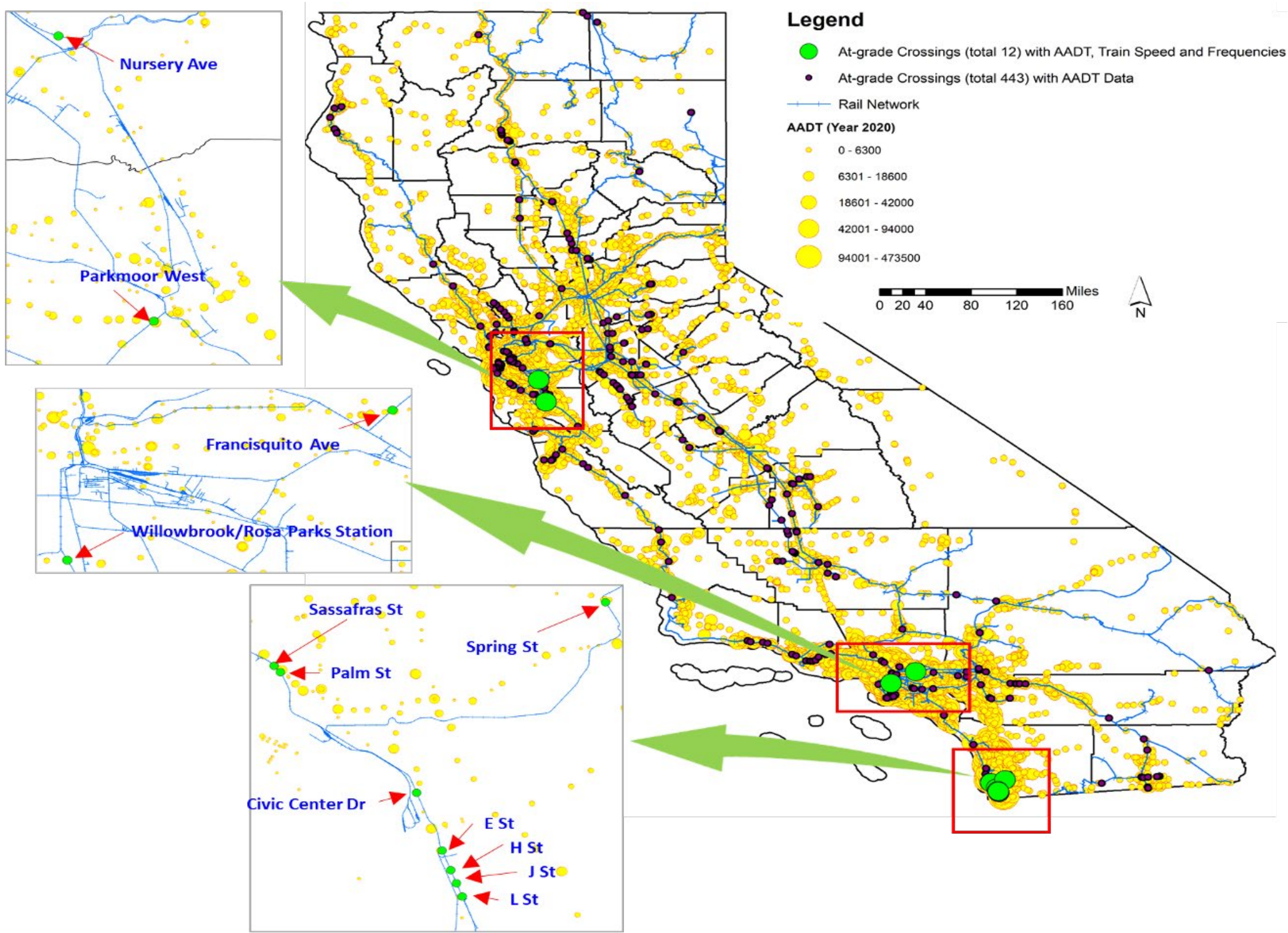

Figure 10. Spatial Distribution of AADT and Key At-Grade Crossings Analyzed 
Table 6. Details of Analyzed Candidate At-Grade Crossings

\begin{tabular}{|c|c|c|c|c|c|c|c|c|c|c|c|c|c|c|}
\hline $\begin{array}{c}\text { DOT } \\
\text { Crossing } \\
\text { ID }\end{array}$ & $\begin{array}{l}\text { Roadway } \\
\text { Name }\end{array}$ & $\begin{array}{l}\text { City or } \\
\text { Town }\end{array}$ & County & $\begin{array}{l}\text { AADT } \\
\text { (Year } \\
\text { 2020) }\end{array}$ & $\begin{array}{l}\text { Number } \\
\text { of Lanes } \\
\text { (one } \\
\text { direction) }\end{array}$ & $\begin{array}{c}\text { Total } \\
\text { Trains } \\
\text { Passing } \\
\text { per Day }\end{array}$ & $\begin{array}{l}\text { Train } \\
\text { Min. } \\
\text { Speed } \\
\text { (mph) }\end{array}$ & $\begin{array}{l}\text { Train } \\
\text { Max. } \\
\text { Speed } \\
\text { (mph) }\end{array}$ & $\begin{array}{l}\text { Number } \\
\text { of Jobs } \\
\text { within } \\
0.25-\text { mile } \\
\text { Radius } \\
(2020)\end{array}$ & $\begin{array}{l}\text { Fatalities } \\
(2010-20)\end{array}$ & $\begin{array}{c}\text { Injuries } \\
(2010-20)\end{array}$ & $\begin{array}{c}\text { Predicted } \\
\text { Collisions } \\
\text { per Year } \\
\text { (FRA, } \\
\text { 2020) }\end{array}$ & $\begin{array}{c}\text { Median } \\
\text { Property } \\
\text { Tax per } \\
\text { Parcel } \\
\text { (Year } \\
\text { 2020) }\end{array}$ & $\begin{array}{c}\text { Number } \\
\text { of } \\
\text { Parcels } \\
\text { within } \\
0.25- \\
\text { mile } \\
\text { Radius }\end{array}$ \\
\hline $747278 U$ & $\begin{array}{l}\text { Francisquito } \\
\text { Ave. }\end{array}$ & $\begin{array}{l}\text { Baldwin } \\
\text { Park }\end{array}$ & $\begin{array}{c}\text { Los } \\
\text { Angeles }\end{array}$ & 16,959 & 2 & 74 & 30 & 70 & 1,996 & 1 & 0 & 0.127 & 2,989 & 830 \\
\hline $912103 \mathrm{U}$ & $\begin{array}{l}\text { Willowbrook/ } \\
\text { Rosa Parks } \\
\text { Station }\end{array}$ & $\begin{array}{c}\text { Los } \\
\text { Angeles }\end{array}$ & $\begin{array}{c}\text { Los } \\
\text { Angeles }\end{array}$ & 17,428 & 1 & 14 & 35 & 55 & 595 & 0 & 4 & 0.044 & 2,989 & 781 \\
\hline 026859B & Sassafras St. & $\begin{array}{l}\text { San } \\
\text { Diego }\end{array}$ & $\begin{array}{l}\text { San } \\
\text { Diego }\end{array}$ & 10,000 & 2 & 209 & 5 & 50 & 1,291 & 0 & 1 & 0.064 & 2,955 & 652 \\
\hline $026861 \mathrm{C}$ & Palm St. & $\begin{array}{c}\text { San } \\
\text { Diego }\end{array}$ & $\begin{array}{c}\text { San } \\
\text { Diego }\end{array}$ & 6,000 & 1 & 209 & 5 & 50 & 2,164 & 0 & 0 & 0.327 & 2,955 & 747 \\
\hline $661808 \mathrm{P}$ & $\begin{array}{l}\text { Civic Center } \\
\text { Dr. }\end{array}$ & $\begin{array}{c}\text { National } \\
\text { City }\end{array}$ & $\begin{array}{l}\text { San } \\
\text { Diego }\end{array}$ & 7,000 & 1 & 418 & 40 & 50 & 974 & 0 & 0 & 0.069 & 2,955 & 551 \\
\hline $662036 \mathrm{~K}$ & L St. & $\begin{array}{l}\text { Chula } \\
\text { Vista }\end{array}$ & $\begin{array}{c}\text { San } \\
\text { Diego }\end{array}$ & 15,984 & 2 & 418 & 40 & 55 & 1,874 & 0 & 0 & 0.270 & 2,955 & 656 \\
\hline $661929 M$ & $\begin{array}{l}\text { Spring St. } \\
\text { (North) }\end{array}$ & La Mesa & $\begin{array}{c}\text { San } \\
\text { Diego }\end{array}$ & 6,000 & 2 & 294 & 25 & 40 & 3,481 & 0 & 1 & 0.001 & 2,955 & 651 \\
\hline $662034 W$ & J St. & $\begin{array}{l}\text { Chula } \\
\text { Vista }\end{array}$ & $\begin{array}{c}\text { San } \\
\text { Diego }\end{array}$ & 16,589 & 2 & 418 & 40 & 55 & 658 & 0 & 0 & 0.083 & 2,955 & 688 \\
\hline $662161 X$ & E St. & $\begin{array}{l}\text { Chula } \\
\text { Vista }\end{array}$ & $\begin{array}{c}\text { San } \\
\text { Diego }\end{array}$ & 23,750 & 2 & 418 & 40 & 55 & 217 & 0 & 0 & 0.085 & 2,955 & 576 \\
\hline $662163 \mathrm{~L}$ & H St. & $\begin{array}{l}\text { Chula } \\
\text { Vista }\end{array}$ & $\begin{array}{c}\text { San } \\
\text { Diego }\end{array}$ & 22,718 & 2 & 418 & 40 & 55 & 982 & 0 & 0 & 0.085 & 2,955 & 1064 \\
\hline $925806 \mathrm{~J}$ & $\begin{array}{l}\text { Parkmoor } \\
\text { West }\end{array}$ & $\begin{array}{c}\text { San } \\
\text { Jose }\end{array}$ & $\begin{array}{l}\text { Santa } \\
\text { Clara }\end{array}$ & 5,381 & 2 & 234 & 35 & 55 & 1,913 & 0 & 0 & 0.002 & 4,694 & 432 \\
\hline $749787 X$ & Nursery Ave. & Fremont & Alameda & 10,932 & 1 & 43 & 20 & 50 & 32 & 0 & 0 & 0.041 & 3,993 & 800 \\
\hline
\end{tabular}




\section{ESTIMATING COST OF SEPARATION}

Data analysis was carried out to understand the impact of AADT on the costs involved in the separation of an at-grade crossing. Sixty different at-grade crossings in California were reviewed for their separation costs. Some of the costs were estimates, while others were actual and involved environmental costs and construction and detour costs. These 60 reviewed at-grade crossings were chosen from the last ten years. The information was available, primarily from Caltrans (Proposition 1B, 2020) and a publicly available grade separation priority report on at-grade crossings in California's Kern County (Kern Council of Governments, 2020).

The graph in Figure 11 shows the variation in AADT versus costs (estimated or actual) for separating the at-grade crossings. The information presented in Figure 11 helps determine the cost of separation of a railroad-highway at-grade crossing if AADT at that crossing is known. AADT has been assumed to be the independent variable in the analysis. Based on the regression results (see Table 7), the linear variation in an at-grade crossing separation cost versus AADT noted at these crossings was found to be significant at a $95 \%$ confidence interval (i.e., $p<0.005$ ). The statistical results were used to estimate the costs that could be incurred in separating candidate at-grade crossings analyzed in this research. The upper bound and lower bound lines for costs were constructed, along with the actual estimates, as shown in Figure 11.

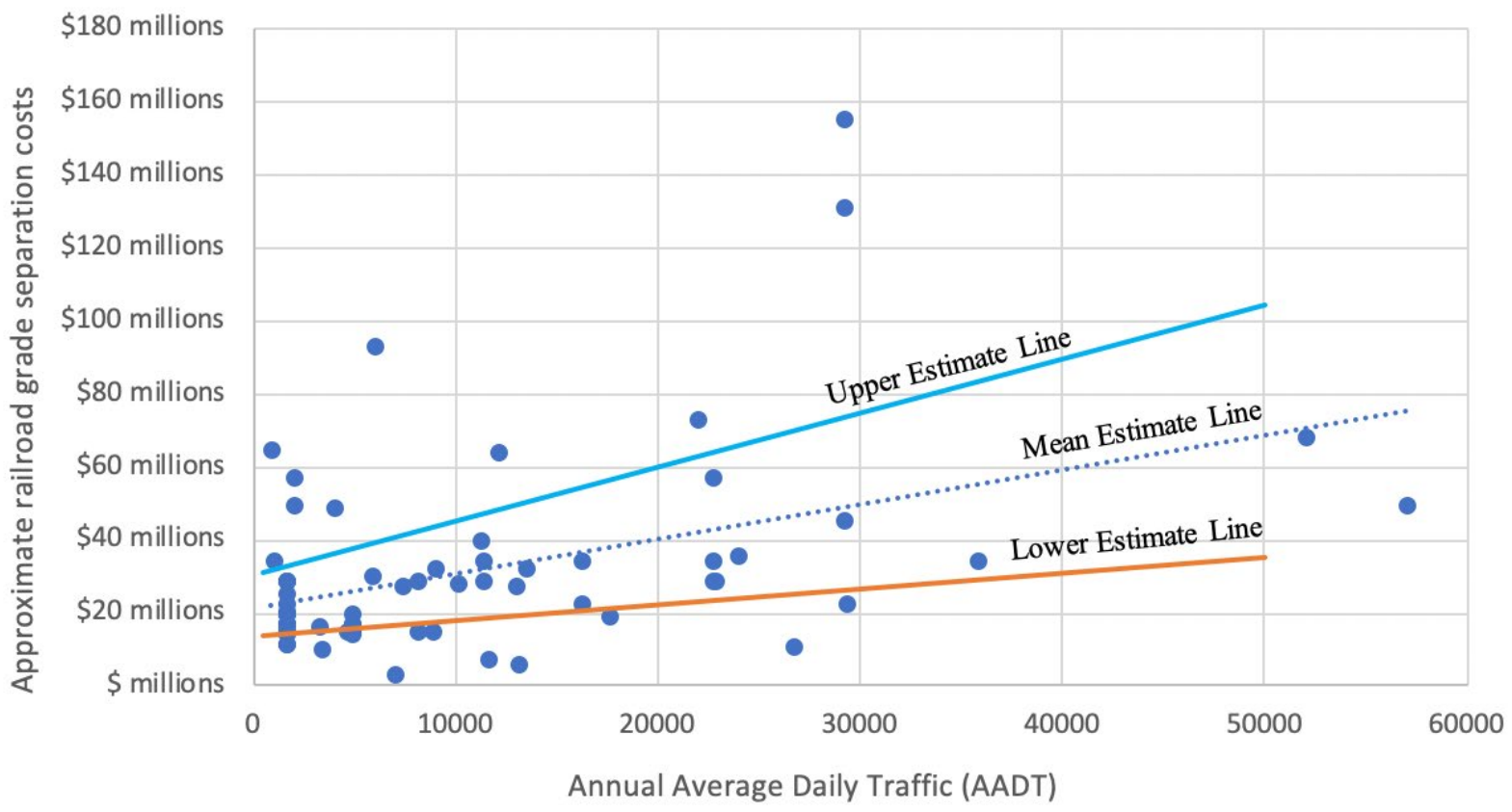

Figure 11. Grade Separation Costs Variation with AADT 
Table 7. Regression Statistics for the Correlation between AADT and Cost

\begin{tabular}{lr}
\hline \multicolumn{2}{c}{ Regression Statistics } \\
\hline Multiple R & 0.435128015 \\
R squared & 0.189336389 \\
Adjusted R squared & 0.17535943 \\
Standard error & 25104947.79 \\
Observations & 60
\end{tabular}

\section{ANOVA}

\begin{tabular}{|c|c|c|c|c|c|}
\hline & $d f$ & SS & $M S$ & $F$ & Significance $F$ \\
\hline Regression & 1 & $8.53768 E+15$ & $8.54 E+15$ & 13.54632 & 0.000511941 \\
\hline Residual & 58 & $3.6555 \mathrm{E}+16$ & $6.3 E+14$ & & \\
\hline Total & 59 & $4.50927 \mathrm{E}+16$ & & & \\
\hline
\end{tabular}

\begin{tabular}{lrrrrrr}
\hline & Coefficients & Standard Error & \multicolumn{1}{c}{-stat } & \multicolumn{1}{c}{$p$-value } & Lower 95\% & Upper 95\% \\
\hline Intercept & 21919754.09 & 4314652.5 & 5.080306 & $4.2 \mathrm{E}-06$ & 13283038.75 & 30556469.44 \\
X variable 1 & 952.689776 & 258.8456089 & 3.680533 & 0.000512 & 434.5539949 & 1470.825557 \\
\hline
\end{tabular}

\section{ECONOMIC GROWTH POTENTIAL}

Grade separations have the potential to cause an increase in the surrounding economic activity. Travel time savings, crash reductions, and emissions reductions can all be translated into monetary benefits; however, before selecting an at-grade crossing for separation, the potential of a crossing to yield any estimated economic benefit can be evaluated. The method proposed below can serve as a quick check to identify key atgrade crossings for further application of BCA, especially when the number of crossings that are to be analyzed is large.

A preliminary evaluation of a grade separation can be carried out by using the technique of assessing economic growth potential. Several existing studies have used this technique to advocate economic growth through rail station and transit-oriented developments (Zhang and Yen, 2020; Murakami and Cervero, 2010; Belzer et al., 2011; Zandiatashbar et al., 2019). Although the technique has been used for various transportation improvement projects, similar evaluations for railroad at-grade crossings have been minimal. A vast majority of studies related to transportation improvement projects consider accessibility increase (as an indicator of economic growth potential) to justify construction or revitalization of transportation facilities (Gutiérrez, 2001; Chandra and Vadali, 2014; Chen et al., 2015). In this research, a similar assumption is made: improvements in vehicular traffic access could enhance economic growth by eliminating the need for the motorists to wait at the crossing while the trains pass at the crossing. The improvement in access $\left(A_{\mathrm{c}}\right)$, assumed to be a gravity-based accessibility model (Chandra and Vadali, 2014), is expressed as: 
$A_{c}=\left(\frac{E_{i}^{\text {after }}}{T_{i}^{\text {after }}}-\frac{E_{i}^{\text {before }}}{T_{i}^{\text {before }}}\right) \times 100 /\left(\frac{E_{i}^{\text {before }}}{T_{i}^{\text {before }}}\right)$

where

$E_{i}^{\text {before }}=$ employment surrounding an at-grade crossing $i$ before separation (year 2020),

$E_{i}^{\text {affer }}=$ future year employment surrounding the at-grade crossing $i$ after separation (year 2040),

$T_{i}^{\text {before }}=$ the total time $\left(T_{i}\right)$ in a day during which gates are closed for traffic for the trains to pass through the crossing $i$ before separation, and

$T_{i}^{\text {after }}=$ the total time $\left(T_{i}\right)$ in a day taken by the traffic to pass through the assumed 0.1 -mile distance through the overpass or underpass of the separated railroad crossing $i$.

The gravity-based accessibility model formulation shown in Eq. (2) shows that the improvement in access $\left(A_{c}\right)$ will be high for those at-grade crossings, which offer an increase in employment surrounding it after separation and a high total delay (in time units) during which the motorists wait at the closed gates while the trains pass before separation. 


\section{RESULTS}

The application of the BCA methodology presented in this research requires first estimating the economic growth potential of candidate at-grade crossings. Decision-makers can use this procedure as guidance to identify key at-grade crossings to focus on for separation outcomes from among several crossings. This saves time in analyzing several at-grade crossings (which could number in the thousands) and gives a reasonably good idea for stakeholders of where the investment for separations could be the most rewarding in terms of economic growth of the surrounding area around the separated crossing. Therefore, the access improvement formula in Eq. (2) is used to determine crossings that could potentially yield high economic growth outputs in terms of business expansions and employment increase in their vicinity after separation.

To demonstrate the application of the methodology described in this research, the authors carried out analysis across twelve at-grade crossings that experience high vehicular and train traffic in California. These twelve at-grade crossings are located at the following highways: Francisquito Ave., Willowbrook/Rosa Parks Station, Sassafras St., Palm St., Civic Center Dr., L St., Spring St. (North), J St., E St., H St., Parkmoor West, and Nursery Ave. Data in Table 8 show the employment figures for years 2020 and 2040 within a quarter-mile distance surrounding each at-grade crossing. The table also shows the rate of change in employment along with the travel times before and after the grade separation. The rates are derived from employment data of the years 2012 through 2017 from the Longitudinal Employer-Household Dynamics (LEHD, 2020) and extrapolated to obtain 2020 and 2040 employment.

As evident from the access improvement output compiled in Table 8, nine out of the twelve crossings had a very high economic growth potential evident from high access improvement. Three crossings had reported negative access improvement. This output was noted by considering a long-term evaluation for the year 2040. Specifically, in 2040, the at-grade crossings on J St., L St., H St., Sassafras St., and Palm St. have the potential for high economic output resulting from the employment changes in the surrounding quarter-mile radius and reductions in travel times after their separation. Thus, the policy recommendation on this outcome is an encouragement to consider separating one or more of these four atgrade crossings. However, in making these decisions, the site-specific constraints need to be considered, so that separation costs do not offset the economic advantages expected. 
Table 8. Access Improvements of the Crossings After Separation

\begin{tabular}{lrrrrrr}
\hline Roadway Name & $\begin{array}{c}\text { Year 2020 } \\
\text { Employment } \\
\text { (before) }\end{array}$ & $\begin{array}{c}\text { Projected } \\
\text { Year 2040 } \\
\text { Employment } \\
\text { (after) }\end{array}$ & $\begin{array}{c}\text { Rate of } \\
\text { Growth in } \\
\text { Employment } \\
\text { per Year }\end{array}$ & $\begin{array}{c}\text { Total Gate } \\
\text { Down Time } \\
\text { per Day at a } \\
\text { Crossing in } \\
\text { Hours in the } \\
\text { Year 2020 } \\
\text { (before) }\end{array}$ & $\begin{array}{c}\text { Travel } \\
\text { Time in } \\
\text { Hours after } \\
\text { Separation } \\
\text { in the Year } \\
\text { 2040 (after) }\end{array}$ & $\begin{array}{c}\text { Access } \\
\text { Improvement } \\
\left(A_{c} \text { in \%) }\right.\end{array}$ \\
\hline Francisquito Ave. & 1,996 & 165 & -0.05 & 0.88 & 0.004 & 1720 \\
Willowbrook/Rosa & 595 & 78 & -0.04 & 0.19 & 0.004 & 524 \\
Parks & 1,291 & 1652 & 0.01 & 2.72 & 0.004 & 86805 \\
Sassafras St. & 2,164 & 4403 & 0.05 & 1.66 & 0.004 & 84165 \\
Palm St. & 974 & 0 & -0.06 & 2.23 & 0.004 & - \\
Civic Center Dr. & 1,874 & 4796 & 0.08 & 4.90 & 0.004 & 313338 \\
\hline L St. & 3,481 & 1756 & -0.02 & 1.81 & 0.004 & 22703 \\
\hline Spring St. (North) & 658 & 2179 & 0.12 & 5.11 & 0.004 & 422787 \\
\hline J St. & 217 & 0 & -0.11 & 7.79 & 0.004 & - \\
E St. & 982 & 912 & 0.00 & 7.38 & 0.004 & 171338 \\
\hline H St. & 1,913 & 509 & -0.04 & 0.90 & 0.004 & 5859 \\
Parkmoor West & 32 & 0 & -0.08 & 0.50 & 0.004 & - \\
Nursery Ave. & & & & & & \\
\hline
\end{tabular}

\section{BENEFITS-TO-COST EVALUATION}

The benefits-to-cost evaluation was carried out for all twelve candidate at-grade crossings, and the outputs are presented for the undiscounted and discounted rates of $3 \%$ and $7 \%$ across the three levels of cost estimates (lower, mean, and upper) of Figure 11. Details of the benefits and costs are compiled in Appendix C.

Table 9 shows the separation cost for the at-grade crossing on E St., which has the largest cost when compared to other crossings. This is expected since E St. has the largest AADT.

Table 9. Cost Estimation of the Most Expensive Crossing after Separation

\begin{tabular}{|c|c|c|c|}
\hline \multirow{2}{*}{ Cost Type } & \multicolumn{3}{|c|}{ Cost Estimates } \\
\hline & Lower Cost Estimate & Mean Cost Estimate & Upper Cost Estimate \\
\hline Undiscounted & $\begin{array}{c}\text { E St. } \\
\text { (\$24 million) }\end{array}$ & $\begin{array}{c}\text { E St. } \\
\text { (\$45 million) }\end{array}$ & $\begin{array}{c}\text { E St. } \\
\text { (\$65 million) }\end{array}$ \\
\hline Discounted (3\%) & $\begin{array}{c}\text { ESt. } \\
\text { (\$23 million) }\end{array}$ & $\begin{array}{c}\text { E St. } \\
\text { (\$43 million) }\end{array}$ & $\begin{array}{c}\text { E St. } \\
\text { (\$64 million) }\end{array}$ \\
\hline Discounted (7\%) & $\begin{array}{c}\text { E St. } \\
\text { (\$22 million) }\end{array}$ & $\begin{array}{c}\text { E St. } \\
\text { (\$41 million) }\end{array}$ & $\begin{array}{c}\text { E St. } \\
\text { (\$61 million) }\end{array}$ \\
\hline
\end{tabular}

Based on the benefits-to-cost analysis outputs, the at-grade crossing located on Palm St. yields the largest benefits of $\$ \mathbf{7 . 5}$ million (undiscounted) resulting from safety improvement compared to the eleven other candidate crossings. This was expected, as the location has the largest value of predicted collisions at the crossing (see Table 6). 
The at-grade crossing on $\mathbf{E}$ St. has the largest expected benefit of $\$ \mathbf{6 4 4 k}$ (undiscounted) from travel time savings, as well as the highest savings resulting from emissions reductions: $\$ 5.7 k$ (undiscounted). The benefits result from a high annual average daily traffic passing through the crossing.

For all the combined benefits across safety improvement, travel time savings, emissions reductions, and property tax revenue, the crossing at $\mathbf{H} \mathbf{S t}$. has the potential to yield almost $\$ 79$ million in benefits after separation.

The at-grade crossing on Nursery Ave. shows the largest benefits of $\mathbf{\$ 7 8}$ million (undiscounted) in terms of property tax revenue, mainly because of a high median property tax and the number of parcels that are within the quarter-mile distance surrounding the location. Consequently, the benefits-to-cost ratio for the crossing at Nursery Ave. considering only revenue through property tax is also the largest, with a benefits-to-cost ratio of $\mathbf{4 . 3}$ (undiscounted) at the lower cost estimate of the separation. Thus, this at-grade crossing presents a better opportunity to support EIFDs in being able to pay off loans or debts for its separation among the rest of the eleven crossings. EIFDs can be a very effective value capture method for cities to generate revenue through property taxesand with a 30-year return, the revenue could be even higher than for a 20-year period undertaken in the analysis in this research.

The at-grade crossing located on Nursery Ave. has the largest benefits-to-cost ratio of 4.4 (undiscounted, lower cost estimate of separation) for all the benefits combined: safety improvement, travel time savings, emissions reductions, and revenue through property taxes. The other two at-grade crossings at Palm St. in San Diego and H St. in Chula Vista, which have benefits-to-cost ratio close to that of Nursery Ave. could also be considered as candidates for separation (see Table C8, Appendix C).

Without considering the property tax revenue but considering all the other benefits and cost savings combined, the railroad grade separation on Palm St. crossing would have the largest benefits-to-cost ratio of $\mathbf{0 . 4 9}$.

Tables 10 through 13 provide further detail on the above discussion, that is, for the benefits and benefits-to-cost ratio evaluation on the recommended at-grade crossing most eligible for separation for a given set of benefit categories. Tables 11 and 12 show an almost identical benefits-to-cost ratio for the Nursery Ave. crossing, since the magnitude of the revenue from property tax is much higher than the rest of the combined benefits and cost savings from safety improvements, travel time savings, and emissions reductions. 
Table 10. Summary of the Largest Benefits (in dollars) for the Candidate Crossings

\begin{tabular}{|c|c|c|c|c|c|}
\hline \multirow[b]{2}{*}{ Benefit Type } & \multicolumn{4}{|c|}{ Benefits Category } & \multirow[b]{2}{*}{$\begin{array}{c}\text { TOTAL } \\
\text { BENEFITS }\end{array}$} \\
\hline & $\begin{array}{c}\text { Safety } \\
\text { improvement }\end{array}$ & $\begin{array}{l}\text { Travel time cost } \\
\text { savings }\end{array}$ & $\begin{array}{l}\text { Cost savings } \\
\text { through } \\
\text { emissions } \\
\text { reductions }\end{array}$ & $\begin{array}{c}\text { Revenue } \\
\text { through property } \\
\text { taxes }\end{array}$ & \\
\hline Undiscounted & $\begin{array}{c}\text { Palm St. } \\
\text { (\$7.5 million) }\end{array}$ & $\begin{array}{c}\text { E St. } \\
\text { (\$0.64 million) }\end{array}$ & $\begin{array}{l}\text { E St. } \\
(\$ 5.7 \mathbf{~ k})\end{array}$ & $\begin{array}{l}\text { Nursery Ave. } \\
\text { (\$78 million) }\end{array}$ & $\begin{array}{c}\text { HSt. } \\
\text { (\$79 million) }\end{array}$ \\
\hline Discounted (3\%) & $\begin{array}{c}\text { Palm St. } \\
\text { (\$5.3 million) }\end{array}$ & $\begin{array}{c}\text { E St. } \\
\text { (\$0.59 million) }\end{array}$ & $\begin{array}{l}\text { E St. } \\
(\$ 5.2 \mathrm{k})\end{array}$ & $\begin{array}{l}\text { Nursery Ave. } \\
\text { (\$58 million) }\end{array}$ & $\begin{array}{c}\text { HSt. } \\
\text { (\$59 million) }\end{array}$ \\
\hline Discounted (7\%) & $\begin{array}{l}\text { Palm St. } \\
\text { (\$3.8 million) }\end{array}$ & $\begin{array}{c}\text { E St. } \\
\text { (\$0.46 million) }\end{array}$ & $\begin{array}{l}\text { E St. } \\
(\$ 4.1 \mathrm{k})\end{array}$ & $\begin{array}{l}\text { Nursery Ave. } \\
\text { (\$42 million) }\end{array}$ & $\begin{array}{c}\text { HSt. } \\
\text { (\$43 million) }\end{array}$ \\
\hline
\end{tabular}

Table 11. Summary of the Largest Benefits-to-Cost Ratio for Nursery Ave.

\begin{tabular}{c|c|c|c}
\hline \multirow{2}{*}{ Estimate Type } & \multicolumn{2}{|c}{ Overall Benefits-to-Cost Ratio: All Benefits Category Combined } \\
\cline { 2 - 3 } & Lower Cost Estimate & Mean Cost Estimate & Upper Cost Estimate \\
\cline { 1 - 2 } Undiscounted & Nusery Ave. & Nusery Ave. & Nusery Ave. \\
& $(\mathbf{4 . 4 )}$ & $(\mathbf{3 . 4})$ & $(\mathbf{2 . 5 )}$ \\
\cline { 1 - 3 } Discounted (3\%) & Nusery Ave. & Nusery Ave. & Nusery Ave. \\
& $(\mathbf{2 . 4 )}$ & $(\mathbf{1 . 9})$ & (1.4) \\
\cline { 1 - 1 } Discounted (7\%) & Nusery Ave. & Nusery Ave. & Nusery Ave. \\
& $(\mathbf{1 . 7 )}$ & $(\mathbf{1 . 3 )}$ & $(\mathbf{0})$ \\
\hline
\end{tabular}

Table 12. Summary of the Largest Benefit-to-Cost Ratio Considering Only Property Tax Revenue for Nursery Ave.

\begin{tabular}{c|c|c|c}
\hline \multirow{2}{*}{ Estimate Type } & \multicolumn{3}{|c}{ Benefits-to-Cost Ratio, Property Tax Revenue } \\
\cline { 2 - 3 } & Lower Cost Estimate & Mean Cost Estimate & Upper Cost Estimate \\
\cline { 1 - 2 } Undiscounted & Nusery Ave. & Nusery Ave. & Nusery Ave. \\
& $(\mathbf{4 . 3 )}$ & $(\mathbf{3 . 3})$ & $(\mathbf{2 . 5})$ \\
\cline { 1 - 1 } Discounted (3\%) & Nusery Ave. & Nusery Ave. & Nusery Ave. \\
& $(\mathbf{2 . 4 )}$ & $(\mathbf{1 . 9})$ & $(\mathbf{1 . 4})$ \\
\cline { 1 - 1 } Discounted (7\%) & Nusery Ave. & Nusery Ave. & Nusery Ave. \\
& $(\mathbf{1 . 7 )}$ & $(\mathbf{1 . 3 )}$ & $(\mathbf{1 . 0 )}$ \\
\hline
\end{tabular}


Table 13. Summary of The Largest Benefits-to-Cost Ratio Considering All Benefits EXCEPT Property Tax Revenue

\begin{tabular}{c|c|c|c}
\hline \multirow{2}{*}{ Estimate Type } & \multicolumn{2}{|c}{ Benefits-to-Cost Ratio, ALL EXCEPT Property Tax Revenue } \\
\cline { 2 - 4 } & Lower Cost Estimate & Mean Cost Estimate & Upper Cost Estimate \\
\hline \multirow{2}{*}{ Undiscounted } & Palm St. & Palm St. & Palm St. \\
& $(\mathbf{0 . 4 9 )}$ & $(\mathbf{0 . 3 6 )}$ & $(\mathbf{0 . 2 7})$ \\
\cline { 1 - 3 } Discounted (3\%) & Palm St. & Palm St. & Palm St. \\
& $(\mathbf{0 . 2 8 )}$ & $(\mathbf{0 . 2 1 )}$ & $(\mathbf{0 . 1 5 )}$ \\
\cline { 1 - 3 } Discounted (7\%) & Palm St. & Palm St. & Palm St. \\
& $(\mathbf{0 . 2 0 )}$ & $(\mathbf{0 . 1 4 )}$ & $(\mathbf{0 . 1 1 )}$ \\
\hline
\end{tabular}

\section{COMPARISON WITH CPUC-BASED GRADE SEPARATION APPROACH}

In determining candidate crossings for separation, the Priority Index Number $(P)$ by CPUC uses the following factors as input: average daily vehicle traffic, average daily freight/commuter train traffic, average daily light rail train traffic, project cost share to be allocated from grade separation fund, number of accidents at crossing, and a value for special conditions factor (see Eq. 1). Considering all trains to be commuter trains passing through a crossing, with equal project cost-share and value for the particular conditions factor, the at-grade railroad crossing at E St. in Chula Vista, San Diego County, would have the largest P. Thus, using the CPUC approach, E St. would have separation/elimination priority among the twelve atgrade crossings analyzed in this study. Table 14 provides the list of crossings in the order of preference for separation/elimination based on CPUC policy.

Table 14. Separation Priority Based on CPUC Priority Index

\begin{tabular}{llc}
\hline \multicolumn{1}{c}{ DOT Crossing ID } & \multicolumn{1}{c}{ Roadway Name } & AADT × Total Trains × (Number of Accidents + 1) \\
\hline $662161 \mathrm{X}$ & E St. & $9,927,500$ \\
$662163 \mathrm{~L}$ & H St. & $9,496,124$ \\
$662034 \mathrm{~W}$ & J St. & $6,934,202$ \\
$662036 \mathrm{~K}$ & L St. & $6,681,312$ \\
026859B & Sassafras St. & $4,180,000$ \\
$661929 \mathrm{M}$ & Spring St. (North) & $3,528,000$ \\
$661808 \mathrm{P}$ & Civic Center Dr. & $2,926,000$ \\
$747278 \mathrm{U}$ & Francisquito Ave. & $2,509,932$ \\
$925806 \mathrm{~J}$ & Parkmoor West & $1,259,154$ \\
026861C & Palm St. & $1,254,000$ \\
$912103 \mathrm{U}$ & Willowbrook/Rosa Parks Station & $1,219,960$ \\
$749787 X$ & Nursery Ave. & 470,076 \\
\hline
\end{tabular}




\section{UNDERPASS/OVERPASS RECOMMENDATION}

Site restrictions at Sassafras St. and Spring St. (see Appendix A, Figs. A3 and A7) limit grade separations at these two streets to be underpass configurations (i.e., rail line below the roadway), while the separations for the rest of the crossings could be overpass configurations (i.e., rail line above the roadway). A brief description is also provided in Appendix $D$ to determine an estimate of costs for underpass and overpass construction involved in the separation of a typical railroad crossing. These costs are in 2020 dollars and are based on a grade separation priority report on at-grade crossings in California's Kern County (Kern Council of Governments, 2020). 


\section{CONCLUSIONS}

Rail infrastructure improvements have a significant impact on the economic development of a region. These improvements require investments that are often limited. The goal of this research is to evaluate financing mechanisms and economic benefits to fund railroad at-grade separations. Separations are often motivated by the aim of reducing fatalities resulting from vehicle-to-train collisions at the at-grade crossings. Other motivations include travel time savings, increasing mobility for the motorists, especially at crossings that experience heavy vehicular traffic.

Currently, the formula for determining the separation of an at-grade crossing developed by CPUC considers the daily traffic from the movement of people and goods, project costs, and accident history. However, it lacks any consideration of benefits or costs incurred in the separation, which can play a crucial role in utilizing the available funds. There is a pressing need to understand whether railroad at-grade separation projects could impact their neighboring real estate values and whether possibilities exist for leveraging economic benefits to fund grade separation projects through schemes such as value capture techniques. With COVID-19, as current infrastructure spending in California is experiencing a reboot, a BCA approach should be explored for such separations. Therefore, the inclusion of economic factors into the current CPUC guidance would improve the decision-making process in prioritizing an at-grade railroad crossing for separation in California.

The methodology presented in this research relies on BCA and evaluated twelve railroadhighway at-grade crossings in California as examples. These crossings are located at Francisquito Ave., Willowbrook/Rosa Parks Station, Sassafras St., Palm St., Civic Center Dr., L St., Spring St. (North), J St., E St., H St., Parkmoor West, and Nursery Ave. The analysis shows that with the estimated $\mathrm{BC}$ ratios, the railroad crossings at Nursery Ave. in Fremont, Palm St. in San Diego, and H St. in Chula Vista could be ideal candidates for separation. The separation of these at-grade crossings would yield a very high benefitsto-cost ratio. Benefits would include travel time savings, safety improvements, emissions reductions, and revenues from property tax surrounding the crossings. The revenue generated from property tax could be used to fulfill the capital cost needs of separation. Overall, with the methodology used to analyze the economic benefits presented in this research, decision-makers can prioritize the separation of at-grade crossings in a more economically feasible manner. 


\section{APPENDIX A: GOOGLE STREET VIEW OF CANDIDATE AT- GRADE CROSSINGS}

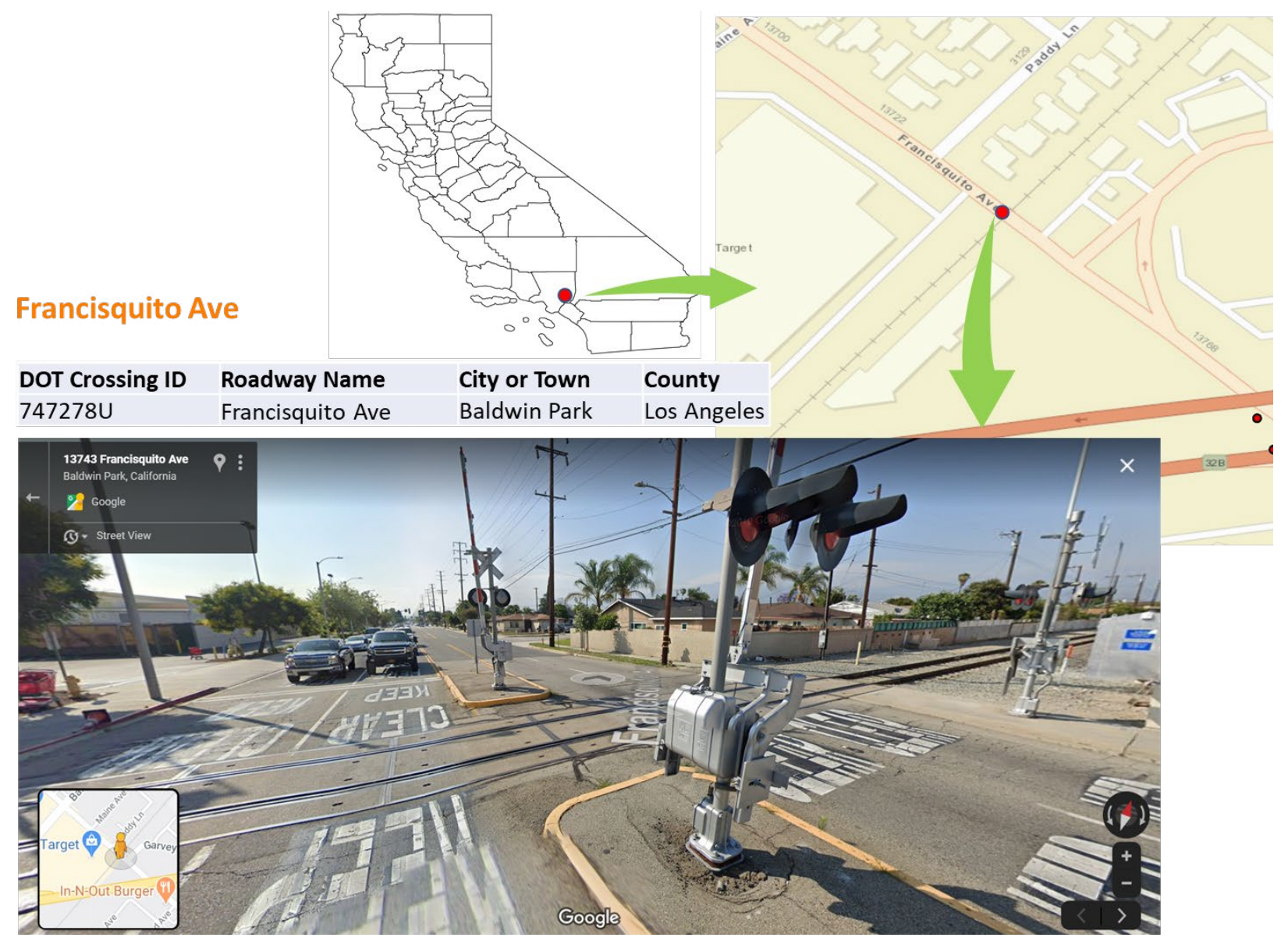

Figure A1. Francisquito Ave. Railroad At-Grade Crossing

(Source: Google Street View) 


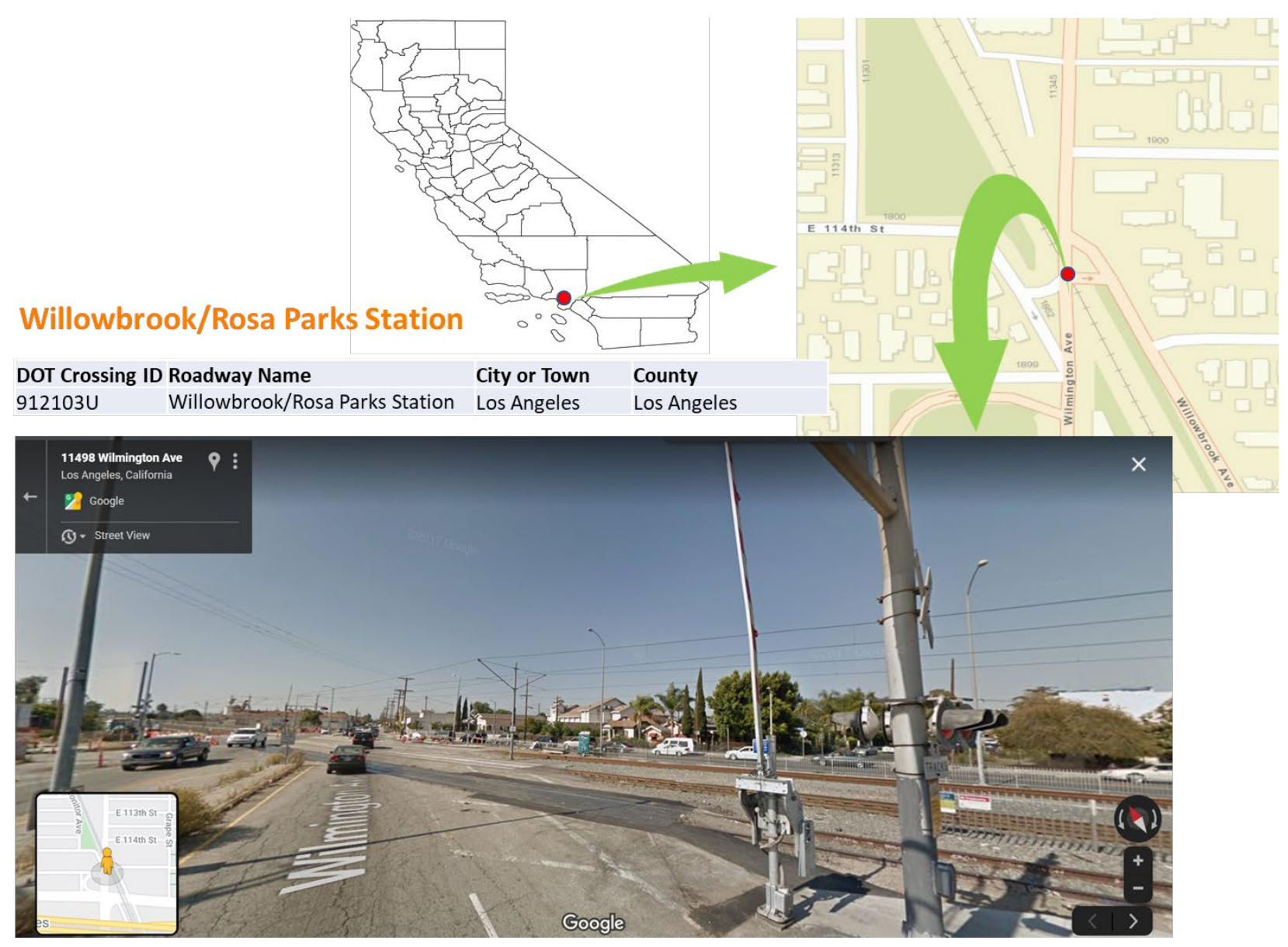

Figure A2. Willowbrook/Rosa Parks Railroad At-Grade Crossing

(Source: Google Street View) 


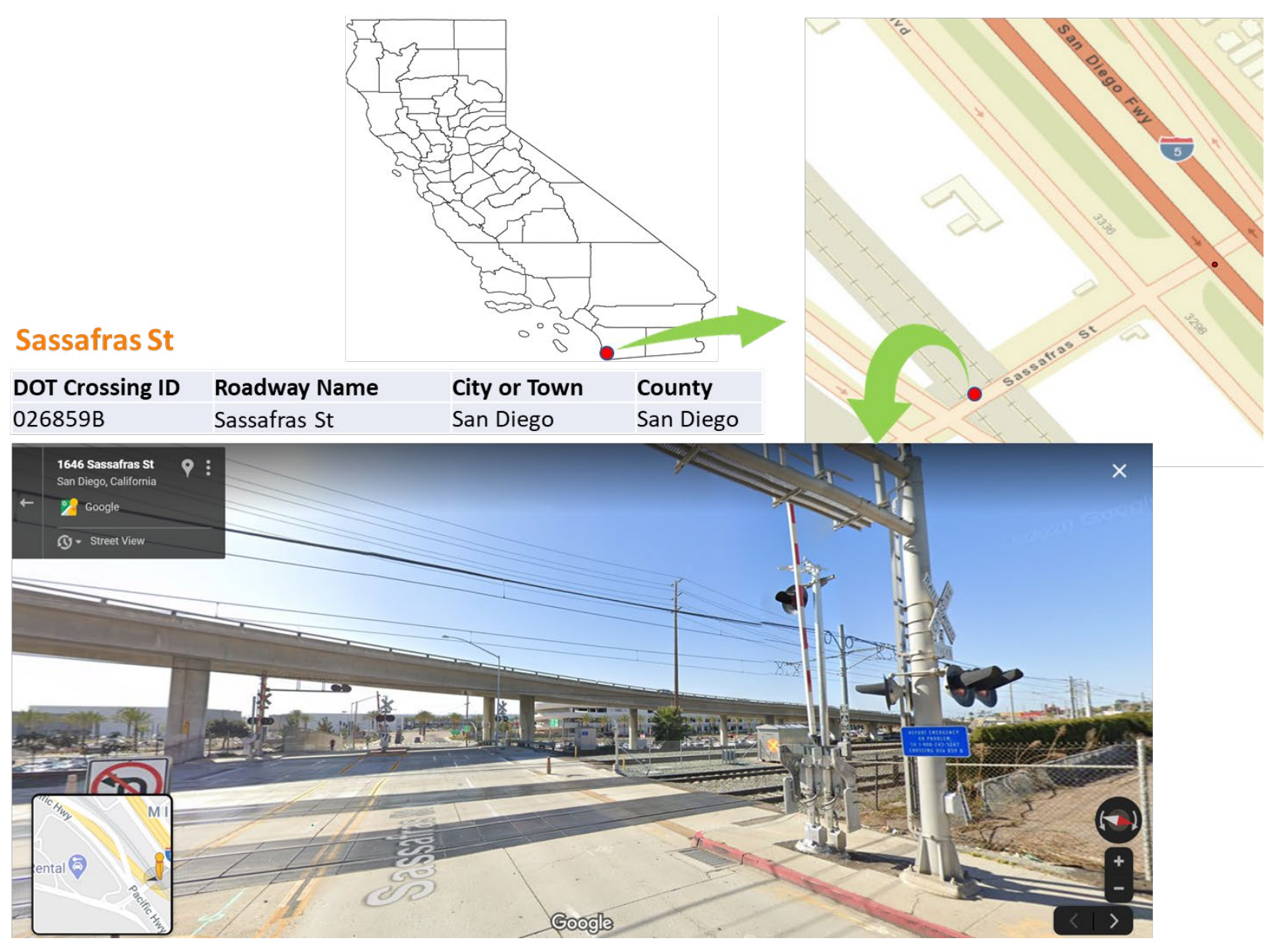

Figure A3. Sassafras St. Railroad At-Grade Crossing

(Source: Google Street View) 


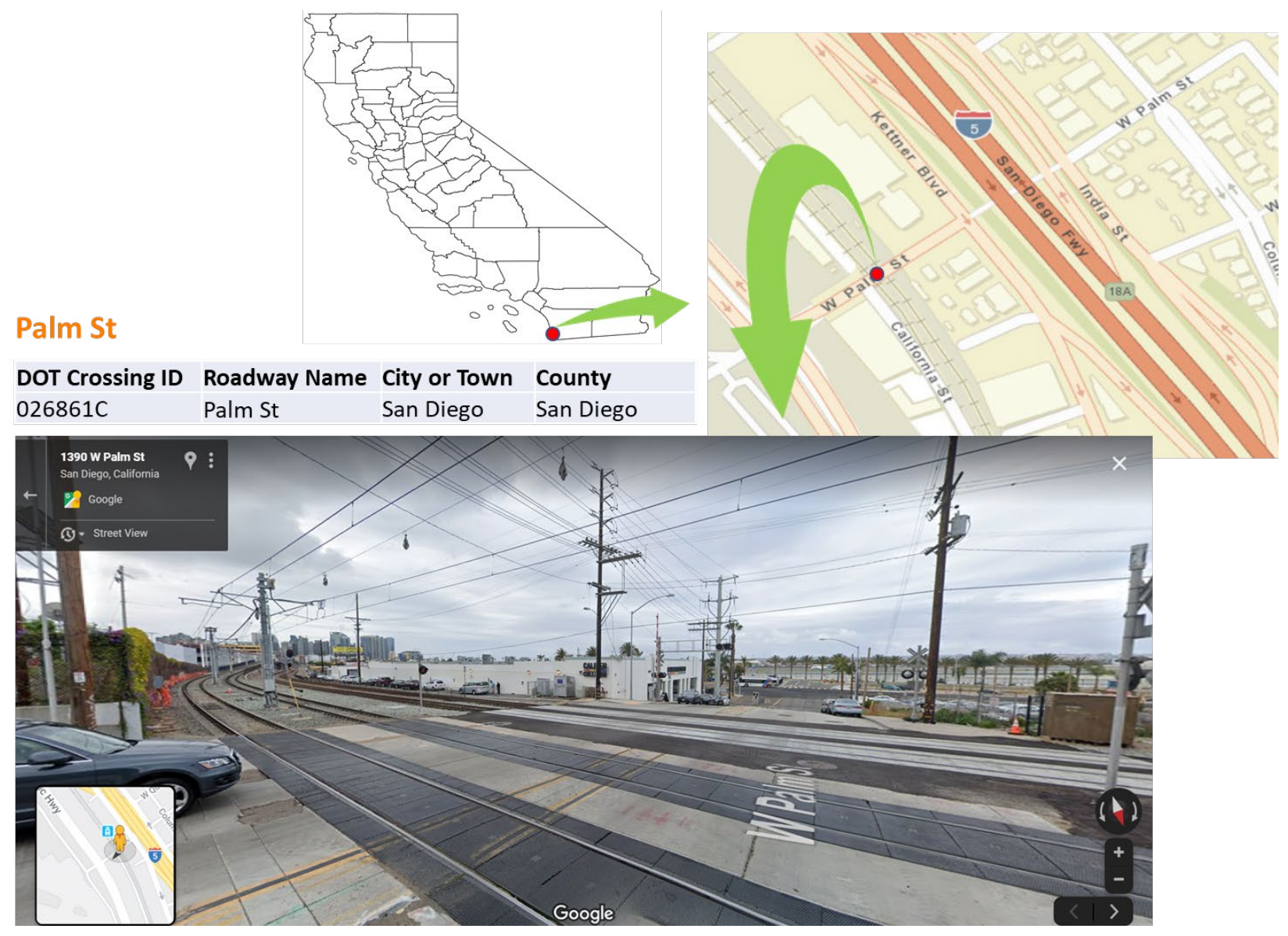

Figure A4. Palm St. Railroad At-Grade Crossing

(Source: Google Street View) 


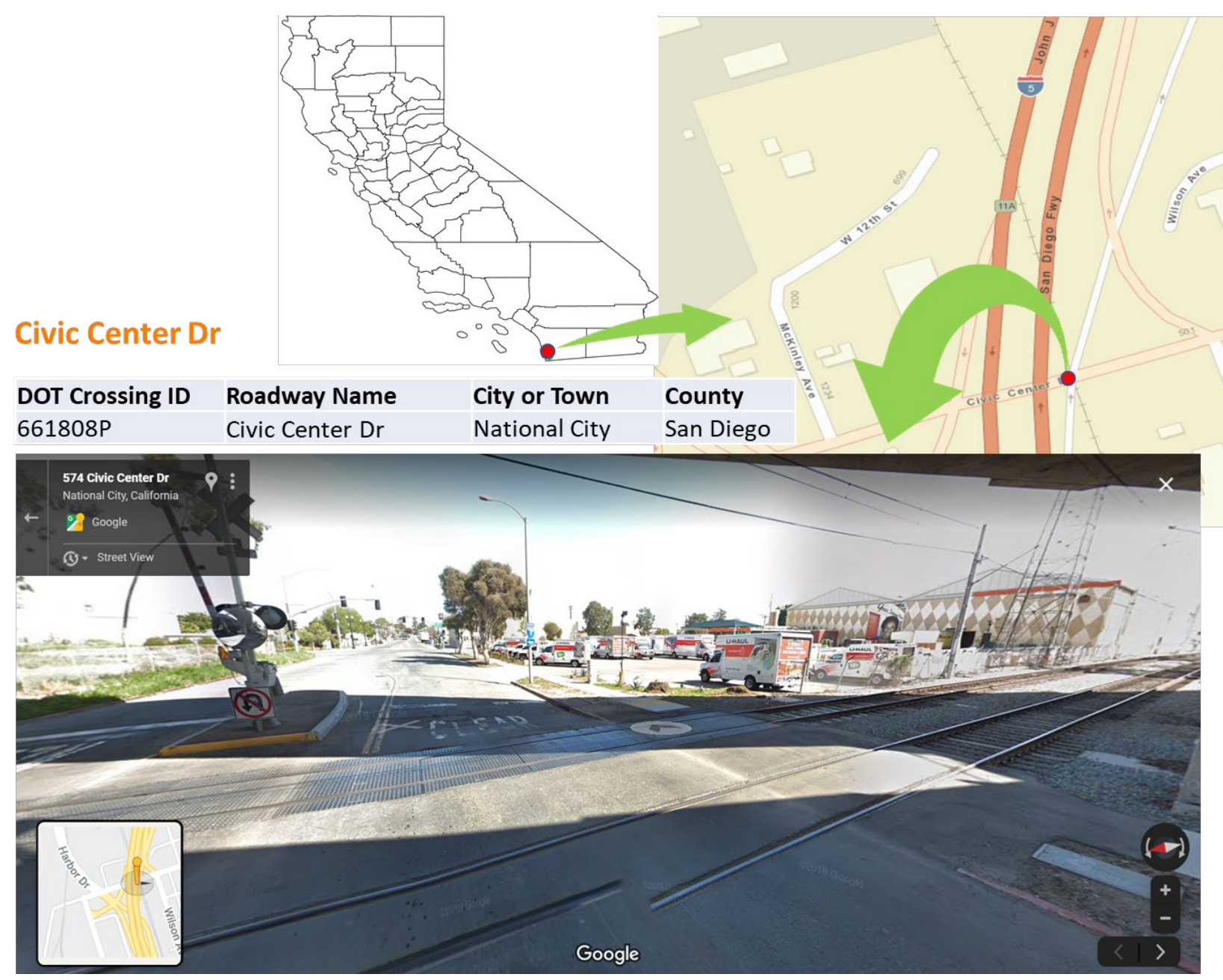

Figure A5. Civic Center Dr. Railroad At-Grade Crossing

(Source: Google Street View) 


\section{St}
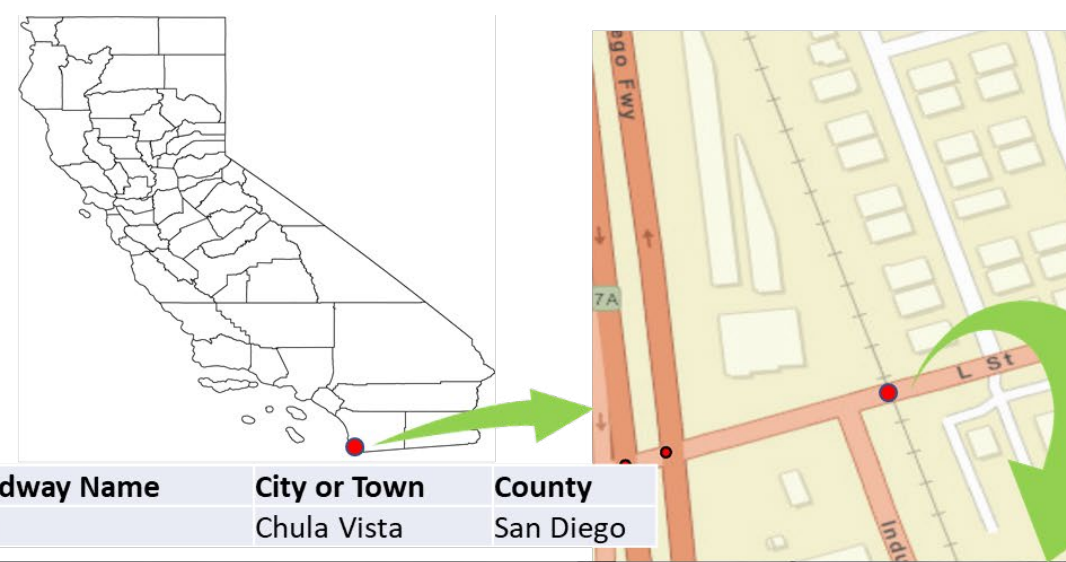
662036K

\section{City or Town}

San Diego

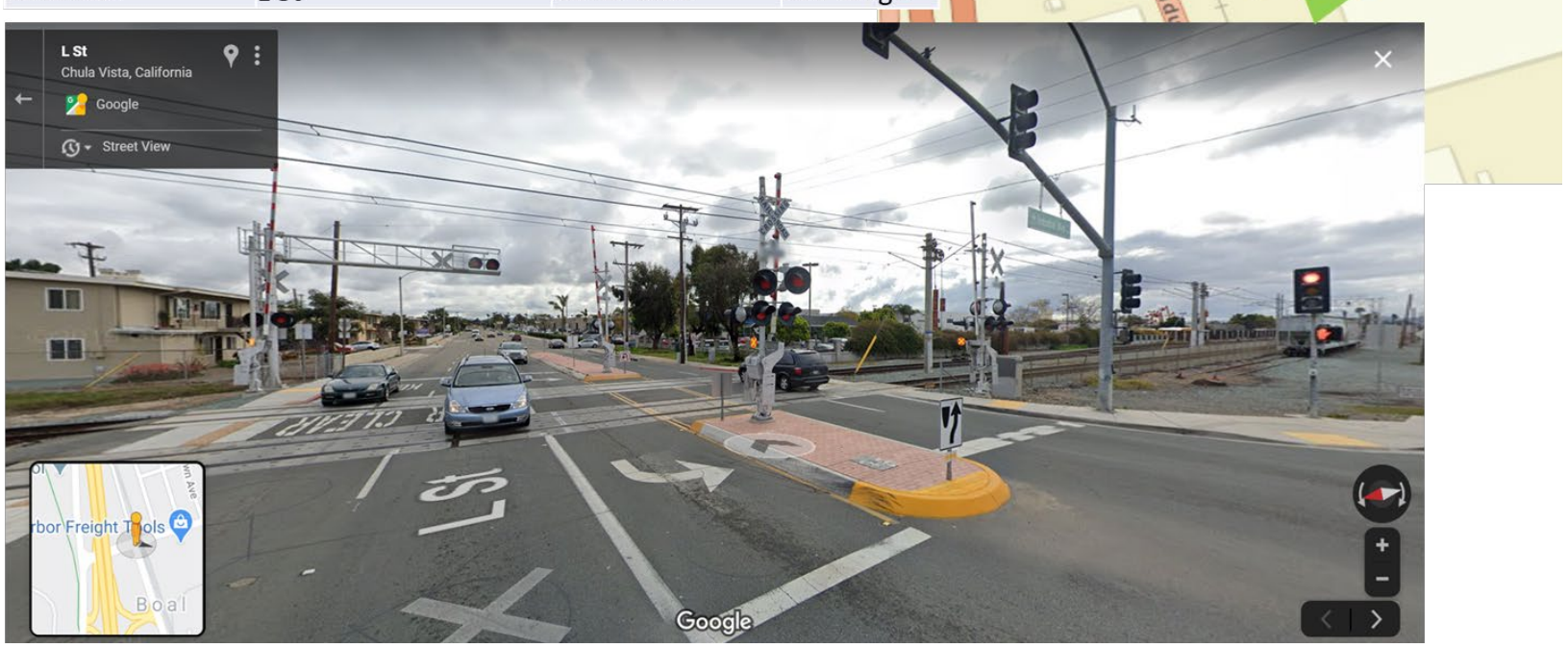

Figure A6. L Street Railroad At-Grade Crossing

(Source: Google Street View) 


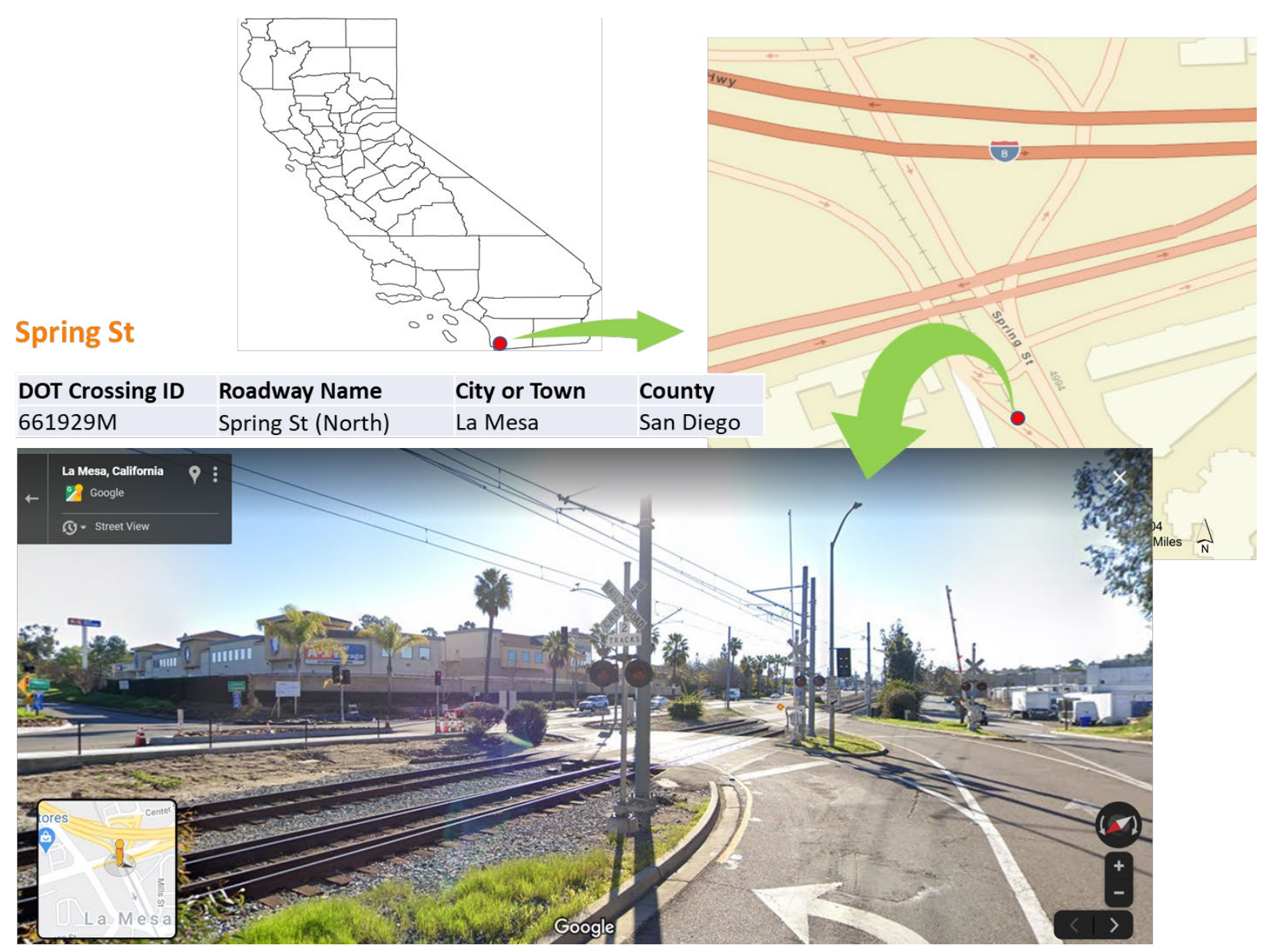

Figure A7. Sprint St. Railroad At-Grade Crossing

(Source: Google Street View) 


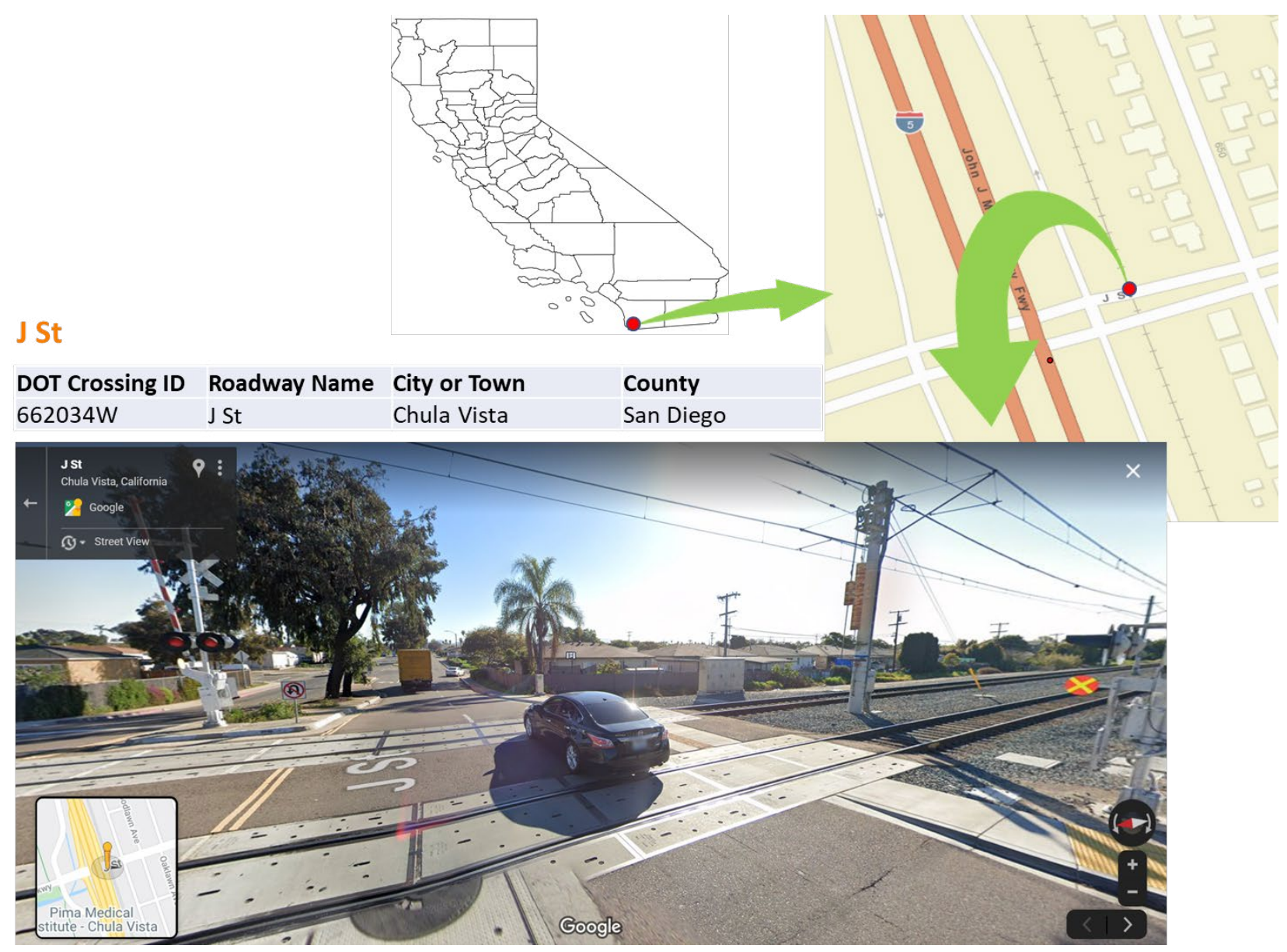

Figure A8. J St. Railroad At-Grade Crossing

(Source: Google Street View) 
E St
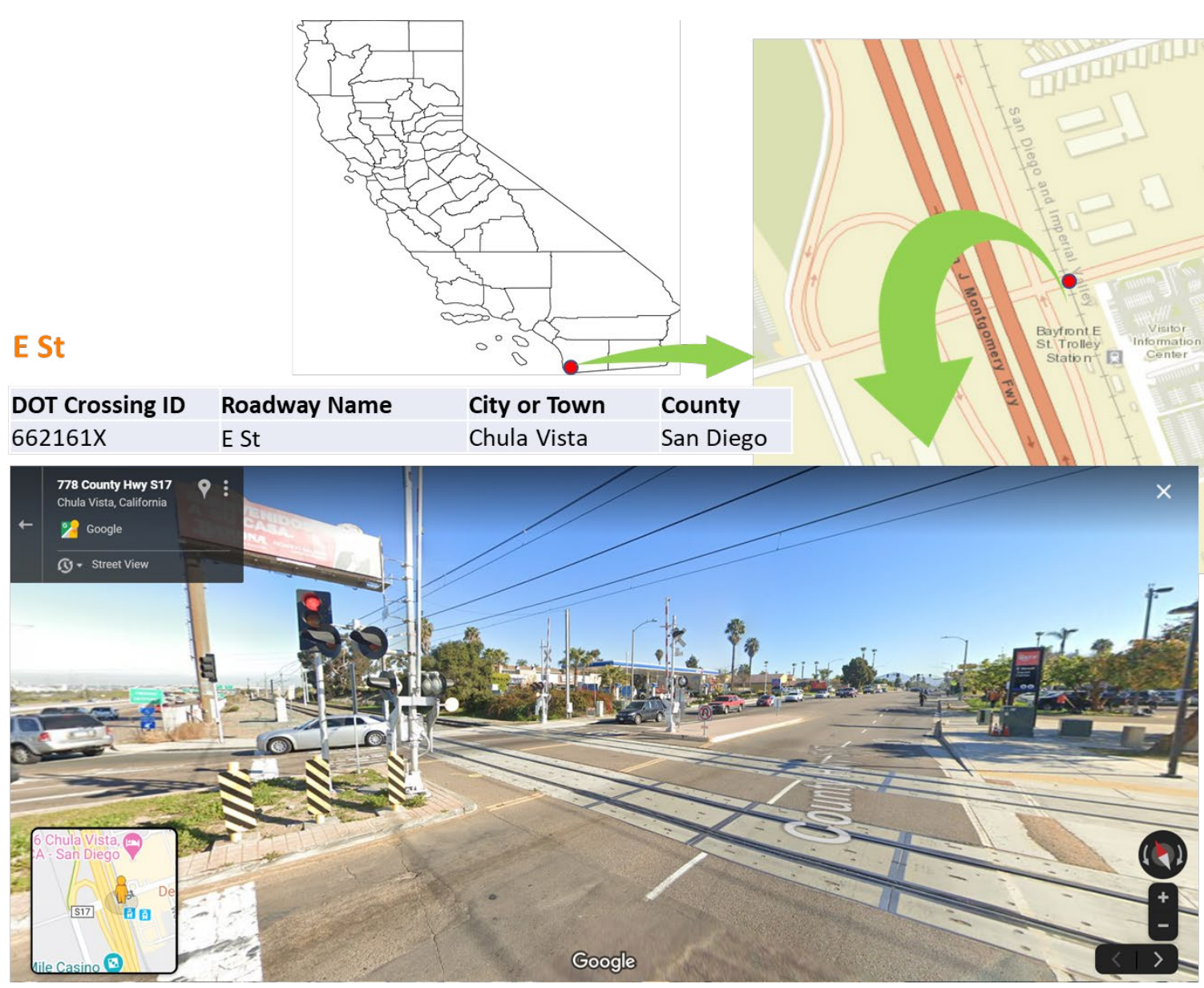

Figure A9. E St. Railroad At-Grade Crossing

(Source: Google Street View) 


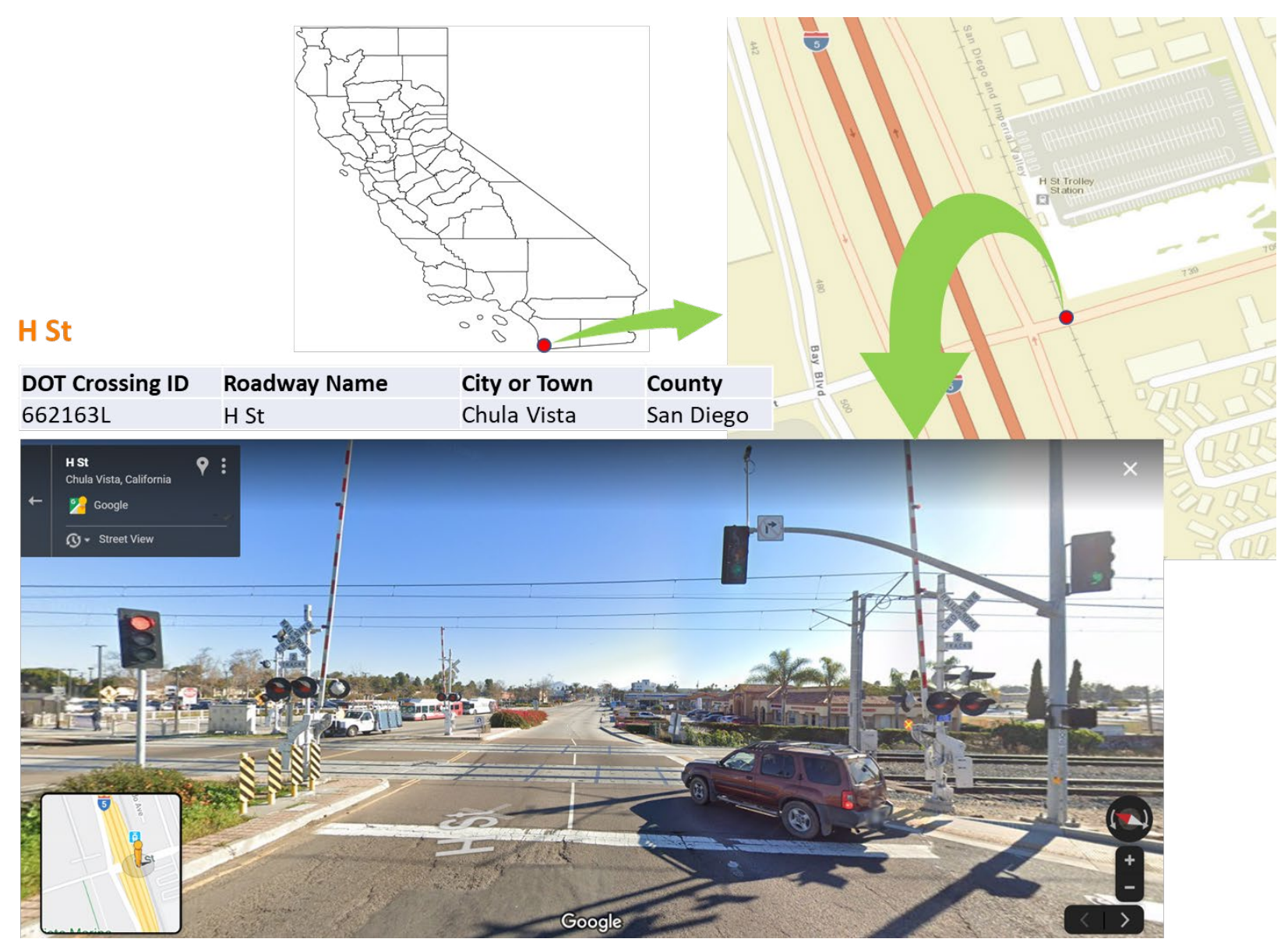

Figure A10. H St. Railroad At-Grade Crossing

(Source: Google Street View) 


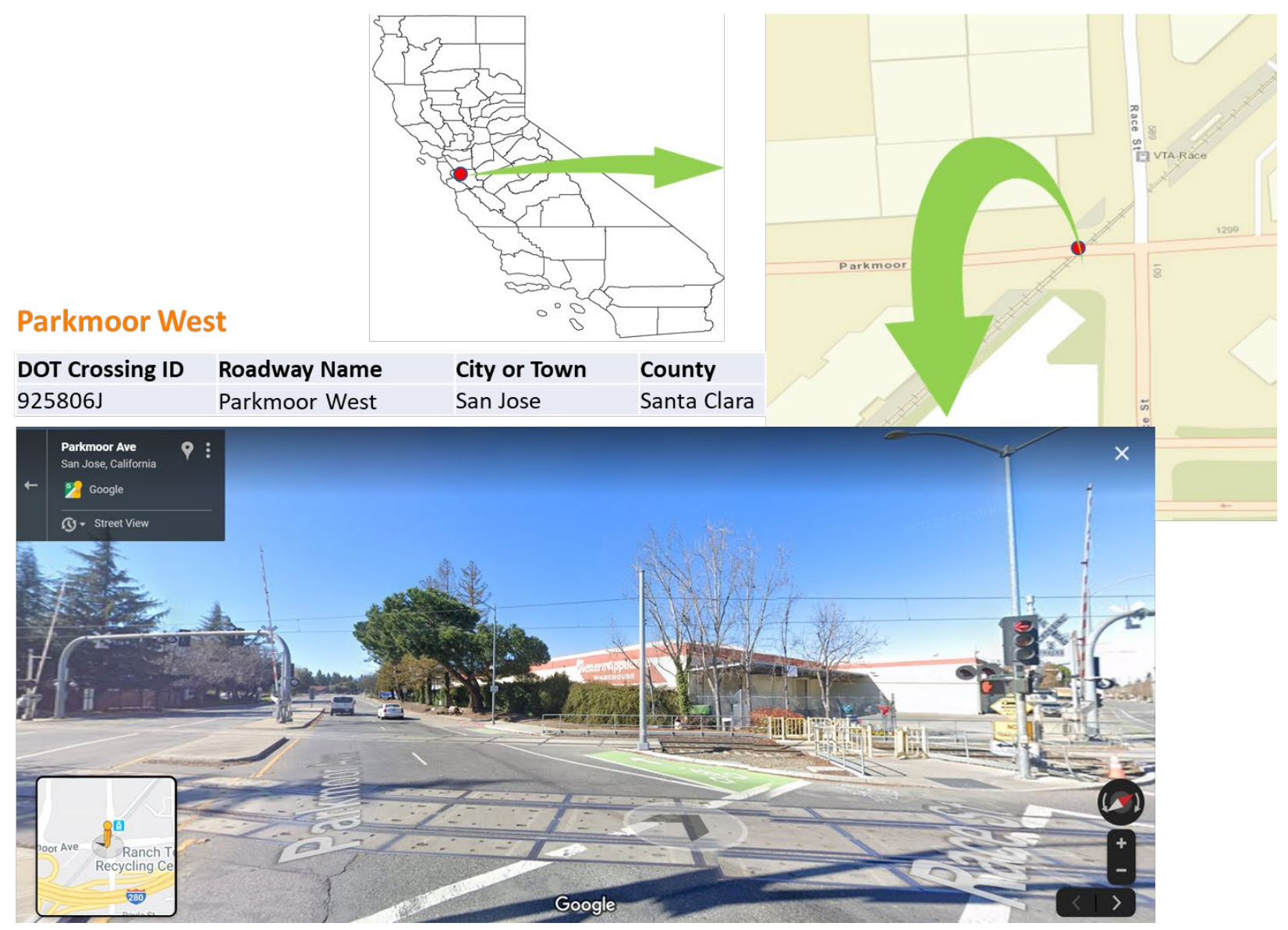

Figure A11. Parkmoor West Railroad At-Grade Crossing

(Source: Google Street View) 


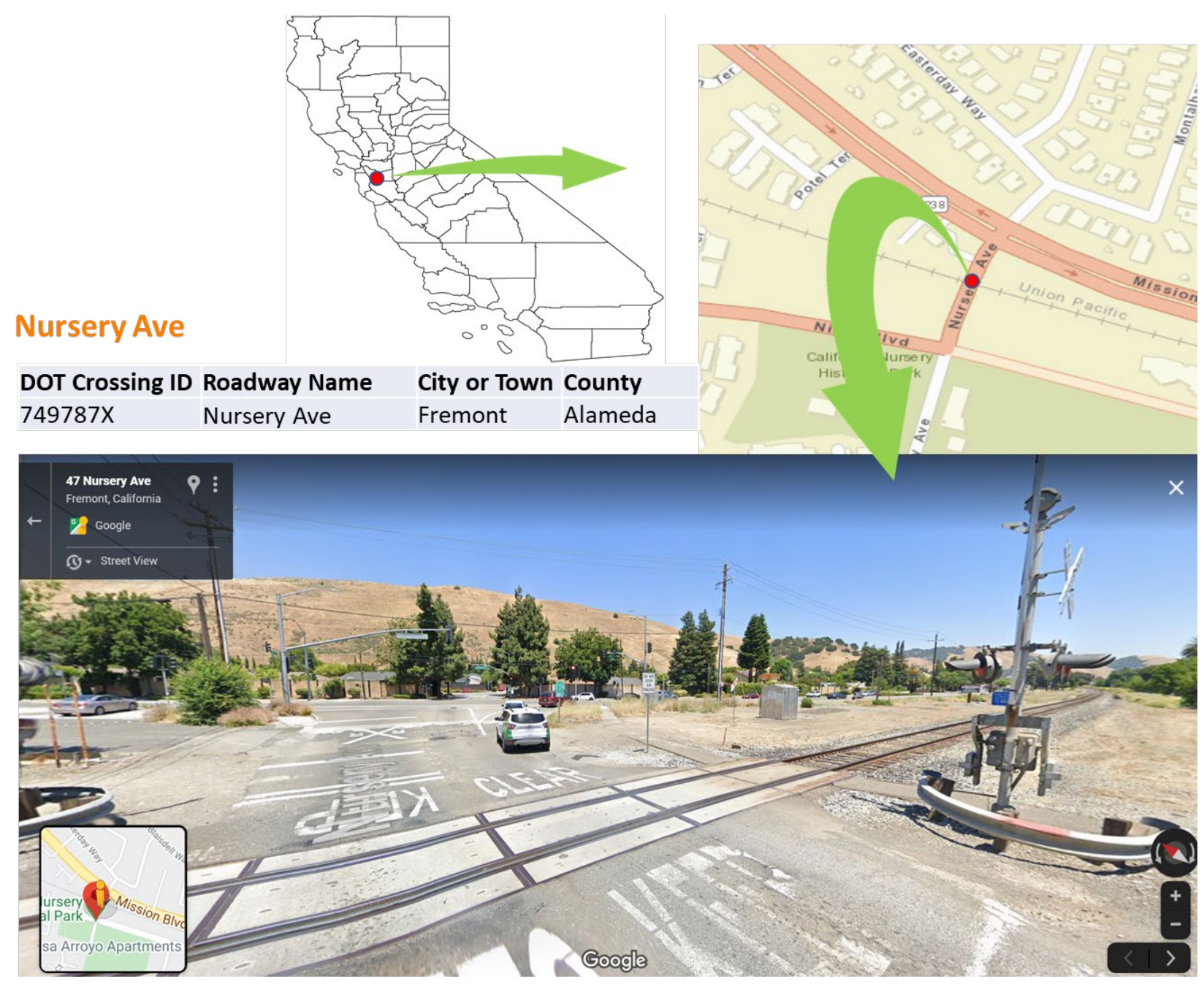

Figure A12. Nursery Ave. Railroad At-Grade Crossing

(Source: Google Street View) 


\section{APPENDIX B: TRAFFIC DELAY FORMULATION}

The authors made conservative assumptions about the inputs needed in estimating traffic delays at an at-grade crossing. Therefore, it was assumed that all trains passing through the at-grade crossing were passenger trains of average length 700 feet: this estimate (700 feet) is based on the assumption that the length of one passenger train car is 85 feet with eight cars per train. Therefore, given that the average time for which the crossing is closed to vehicular traffic by one train is the length of the train divided by its speed, the gate down time for a train per day $\left(T_{i}\right)$ at the crossing $i$ is expressed as

$$
T_{i}=\left(\frac{L}{s_{i}}+t\right) \times n_{i}
$$

where

$L=$ Average length of a train passing through any crossing. The length of $700 \mathrm{ft}$ (or 0.13 miles) is assumed as if all trains passing at the crossing are passenger trains.

$s_{i}=$ The average speed of the trains passing through the crossing $i$. The average of the minimum and maximum train speeds is assumed to be the average train speed.

$t=$ Warning time for gate opening and closure. Assumed to be 10 seconds.

$n_{i}=$ Number of trains passing per day through the at-grade crossing $i$.

Further, assuming that the arrival and departure rates at the crossing are uniform for the vehicles based on queuing theory (as shown in the sketch of Fig. 5 earlier) for the case of a single train passing through the crossing, the delay can be written as:

$$
\frac{1}{2} \times \tau_{i} \times \mu_{i} t_{i}=\frac{1}{2} \times \tau_{i}^{2} \times\left(\frac{\mu_{i} \lambda_{i}}{\mu_{i}-\lambda_{i}}\right)=\frac{1}{2} \times\left(\frac{T_{i}}{n_{i}}\right)^{2} \times\left(\frac{\mu_{i} \lambda_{i}}{\mu_{i}-\lambda_{i}}\right)
$$

Therefore, the total vehicle delay per day at crossing $i$ (denoted by $D_{i}$ ) for the number of trains $n_{i}$ passing per day through the at-grade crossing is

$$
D_{i}=n_{i} \times \frac{1}{2} \times\left(\frac{T_{i}}{n_{i}}\right)^{2} \times\left(\frac{\mu_{i} \lambda_{i}}{\mu_{i}-\lambda_{i}}\right)=\frac{1}{2}\left(\frac{T_{i}^{2}}{n_{i}}\right)\left(\frac{\mu_{i} \lambda_{i}}{\mu_{i}-\lambda_{i}}\right)
$$

where

$\mathrm{m}=$ Vehicle departure rate at the crossing $i$ (vehicle/ lane-hour). Based on the Highway Capacity Manual (HCM, TRB 2001), the departure rates (as saturation flow rates) used are the following: highways $(1,800)$, arterials $(1,400)$, collectors $(900)$, and local roads $(700)$.

$\mathrm{I}_{i}=$ Vehicle arrival rate at the crossing $i$. The arrival rate is calculated by converting the annual average daily traffic $\left(A A D T_{i}\right)$ into vehicles/lane-hour at crossing $i$. 


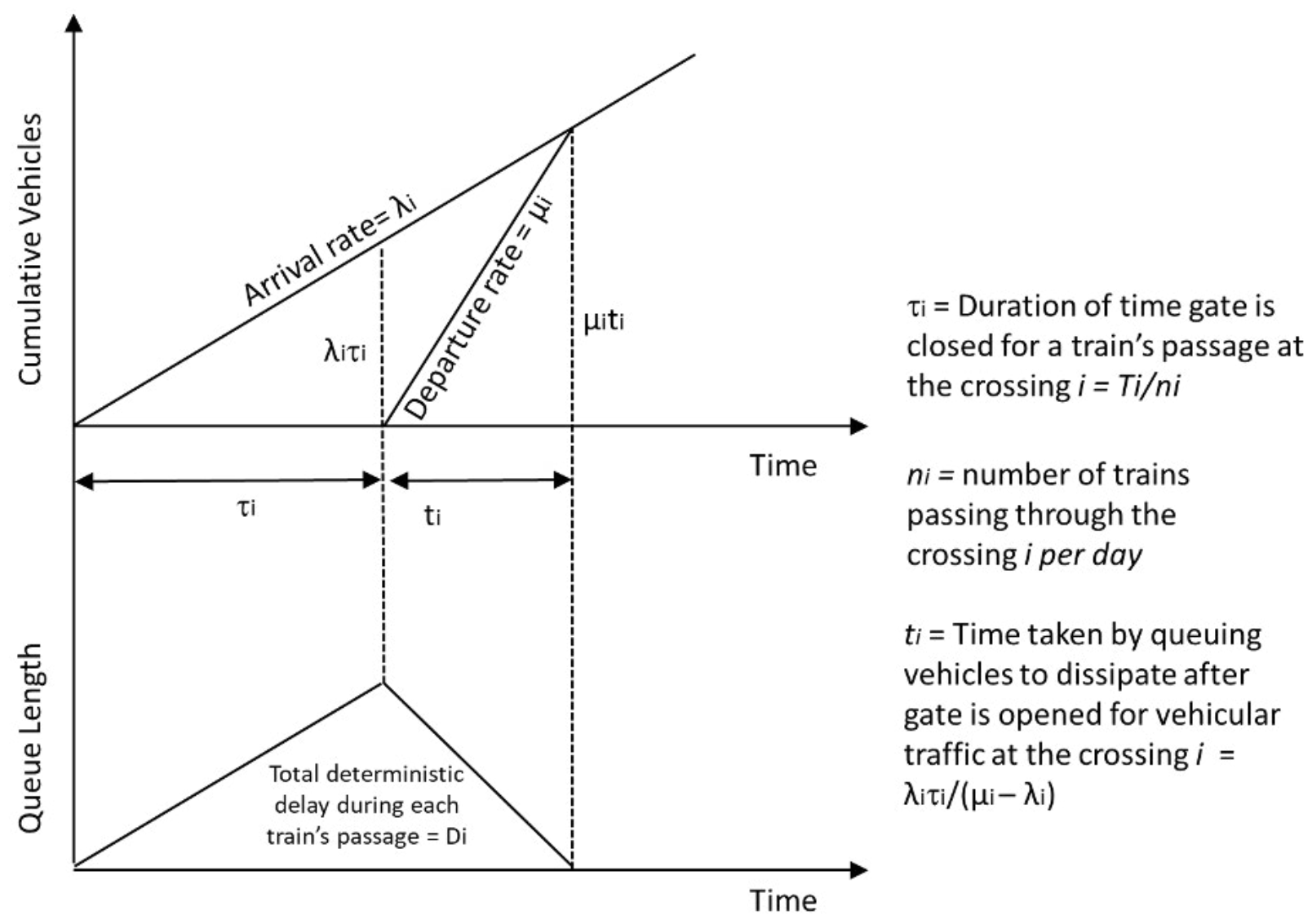

Figure B1. Derivation for Traffic Delay $\left(D_{\mathrm{i}}\right)$ per Day Resulting from a Single Train's
Passage through a Crossing

The total waiting time for the traffic, $T_{i}$, obtained from Eq. B1 will be an approximation but could provide a reasonably good idea about at-grade crossings that are problematic in causing the largest waiting times (representing vehicular delays) at the crossing. 


\section{APPENDIX C: DETAILED OUTPUT OF BENEFITS-TO-COST ANALYSIS}

Table C1. Total Cost Savings (in 2020 dollars) Resulting from Accident Elimination (safety improvement)

\begin{tabular}{lccr}
\hline \multicolumn{1}{c}{ Roadway Name } & $\begin{array}{c}\text { Total Accident Cost } \\
\text { Savings (Undiscounted) }\end{array}$ & $\begin{array}{c}\text { Total Accident Cost } \\
\text { Savings (Discounted at 3\%) }\end{array}$ & $\begin{array}{c}\text { Total Accident Cost } \\
\text { Savings (Discounted at 7\%) }\end{array}$ \\
\hline $\begin{array}{l}\text { Francisquito Ave. } \\
\text { Willowbrook/Rosa }\end{array}$ & $\$ 2,916,911$ & $\$ 3,104,204$ & $\$ 2,505,985$ \\
Parks Station & $\$ 1,003,388$ & $\$ 1,119,225$ & $\$ 913,444$ \\
Sassafras St. & $\$ 1,470,858$ & $\$ 1,149,443$ & \\
Palm St. & $\$ 7,500,900$ & $\$ 5,346,720$ & $\$ 847,790$ \\
Civic Center Dr. & $\$ 1,574,885$ & $\$ 1,122,595$ & $\$ 3,808,387$ \\
L St. & $\$ 6,197,098$ & $\$ 4,417,356$ & $\$ 799,607$ \\
Spring St. (North) & $\$ 22,096$ & $\$ 116,751$ & $\$ 3,146,415$ \\
J St. & $\$ 1,900,887$ & $\$ 1,354,972$ & $\$ 112,219$ \\
E St. & $\$ 1,957,897$ & $\$ 1,395,610$ & $\$ 965,126$ \\
H St. & $\$ 1,950,983$ & $\$ 1,390,681$ & $\$ 994,071$ \\
Parkmoor West & $\$ 49,430$ & $\$ 35,234$ & $\$ 990,561$ \\
Nursery Ave. & $\$ 932,528$ & $\$ 664,716$ & $\$ 25,097$ \\
\hline
\end{tabular}




\section{Safety Improvement Benefits (in 2020 USD)}

$\$ 8,000,000$

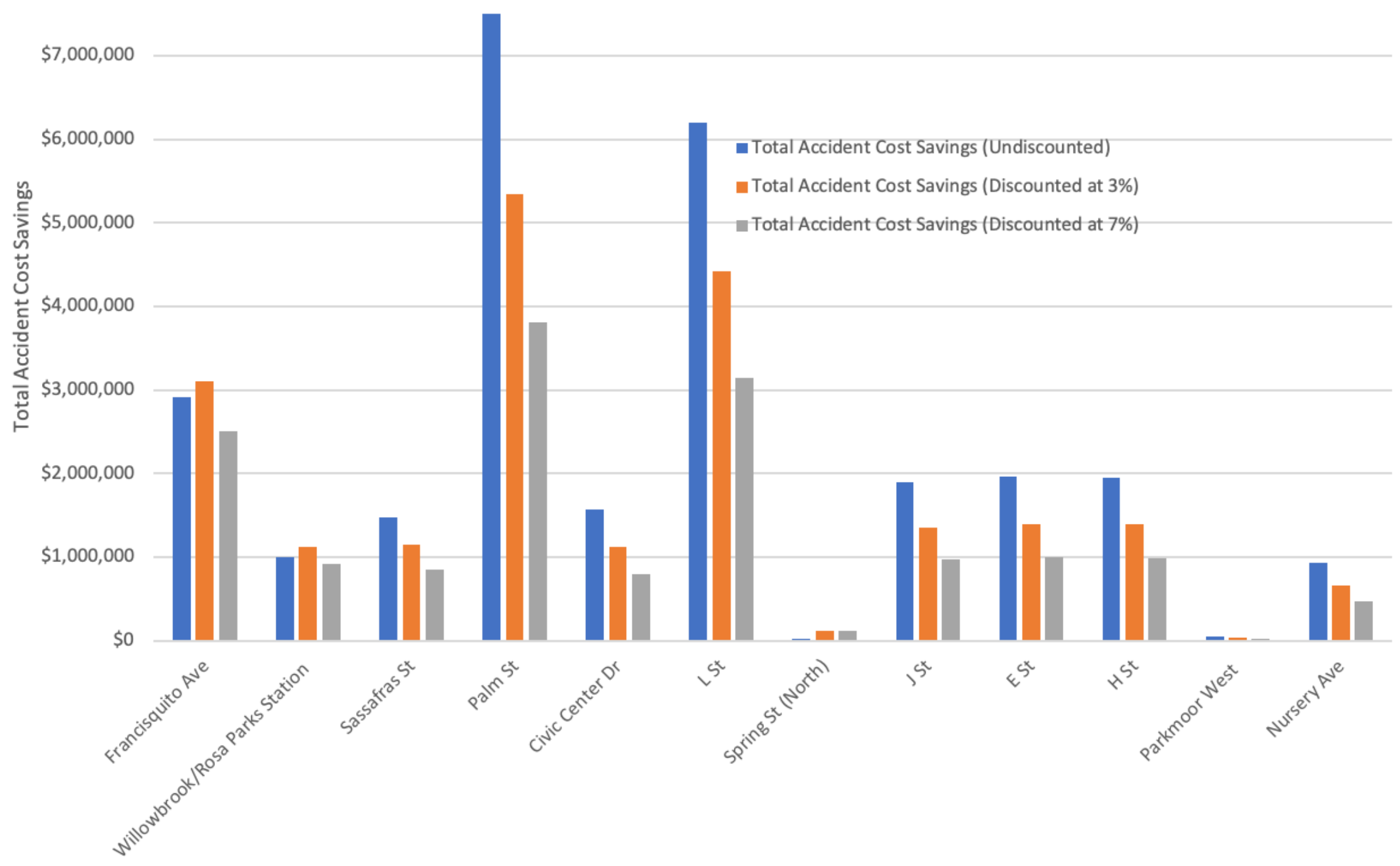

Figure C1. Safety Improvement Cost Savings across the Analyzed At-Grade Crossings in California 
Table C2. Total Travel Time Cost Savings as Benefits (in 2020 USD)

\begin{tabular}{lccc}
\hline \multicolumn{1}{c}{ Roadway Name } & $\begin{array}{c}\text { Total Travel Time } \\
\text { Savings (Undiscounted) }\end{array}$ & $\begin{array}{c}\text { Total Travel Time Savings } \\
\text { (Discounted at 3\%) }\end{array}$ & $\begin{array}{c}\text { Total Travel Time Savings } \\
\text { (Discounted at 7\%) }\end{array}$ \\
\hline $\begin{array}{l}\text { Francisquito Ave. } \\
\text { Willowbrook/Rosa }\end{array}$ & $\$ 72,618$ & $\$ 56,271$ & $\$ 41,081$ \\
Parks Station & $\$ 427,567$ & $\$ 322,800$ & $\$ 227,228$ \\
Sassafras St. & $\$ 385,879$ & & \\
Palm St. & $\$ 237,000$ & $\$ 282,658$ & $\$ 199,929$ \\
Civic Center Dr. & $\$ 177,026$ & $\$ 185,596$ & $\$ 134,705$ \\
L St. & $\$ 391,975$ & $\$ 145,996$ & $\$ 109,141$ \\
Spring St. (North) & $\$ 139,775$ & $\$ 290,637$ & $\$ 208,874$ \\
J St. & $\$ 409,870$ & $\$ 139,943$ & $\$ 111,048$ \\
E St. & $\$ 644,401$ & $\$ 285,345$ & $\$ 199,797$ \\
H St. & $\$ 607,769$ & $\$ 593,186$ & $\$ 457,625$ \\
Parkmoor West & $\$ 68,508$ & $\$ 426,919$ & $\$ 299,220$ \\
Nursery Ave. & $\$ 60,190$ & $\$ 173,360$ & $\$ 159,213$ \\
\hline
\end{tabular}


Travel Time Cost Savings (in 2020 USD)

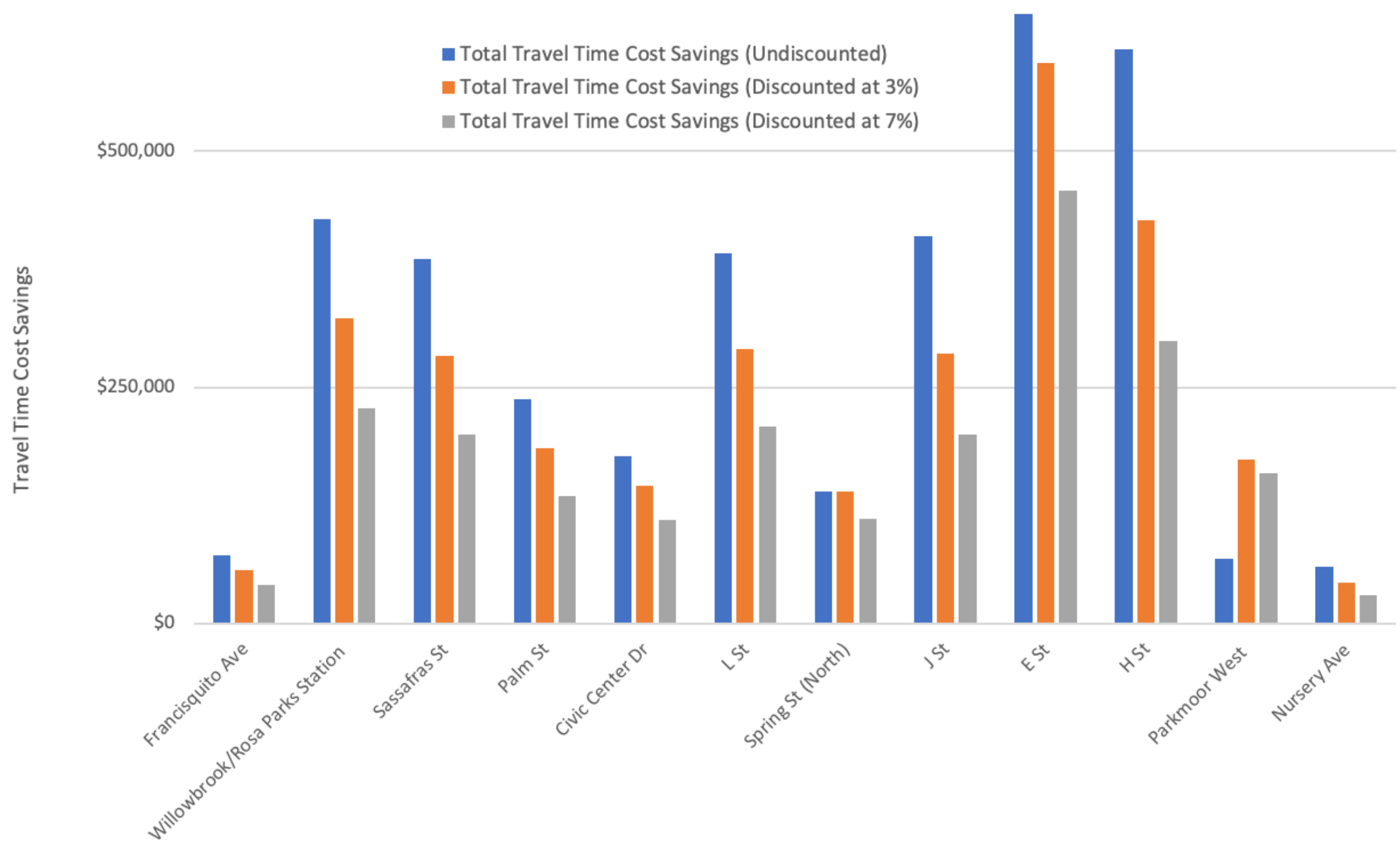

Figure C2. Travel Time Cost Savings across the Analyzed At-Grade Crossings in California 
Table C3. Cost Savings as Benefits (in 2020 dollars) from Emissions Reductions

\begin{tabular}{lccc}
\hline Roadway Name & $\begin{array}{c}\text { Total Cost Savings from } \\
\text { Emissions Reductions } \\
\text { (Undiscounted) }\end{array}$ & $\begin{array}{c}\text { Total Cost Savings from } \\
\text { Emissions Reductions } \\
\text { (Discounted at 3\%) }\end{array}$ & $\begin{array}{c}\text { Total Cost Savings from } \\
\text { Emissions Reductions } \\
\text { (Discounted at 7\%) }\end{array}$ \\
\hline Francisquito Ave. & $\$ 644$ & $\$ 499$ & $\$ 364$ \\
$\begin{array}{l}\text { Willowbrook/Rosa } \\
\text { Parks Station }\end{array}$ & $\$ 3,791$ & $\$ 2,862$ & $\$ 2,015$ \\
Sassafras St. & $\$ 3,422$ & $\$ 2,506$ & $\$ 1,773$ \\
Palm St. & $\$ 2,102$ & $\$ 1,646$ & $\$ 1,194$ \\
Civic Center Dr. & $\$ 1,570$ & $\$ 1,295$ & $\$ 968$ \\
L St. & $\$ 3,476$ & $\$ 2,577$ & $\$ 1,852$ \\
Spring St. (North) & $\$ 1,239$ & $\$ 1,241$ & $\$ 985$ \\
J St. & $\$ 3,634$ & $\$ 2,530$ & $\$ 1,772$ \\
E St. & $\$ 5,714$ & $\$ 5,260$ & $\$ 4,058$ \\
H St. & $\$ 5,389$ & $\$ 3,786$ & $\$ 2,653$ \\
Parkmoor West & $\$ 607$ & $\$ 1,537$ & $\$ 1,412$ \\
Nursery Ave. & $\$ 534$ & $\$ 385$ & $\$ 270$ \\
\hline
\end{tabular}


Cost Savings from Emissions Reductions (in 2020 USD)

$\$ 7,000$

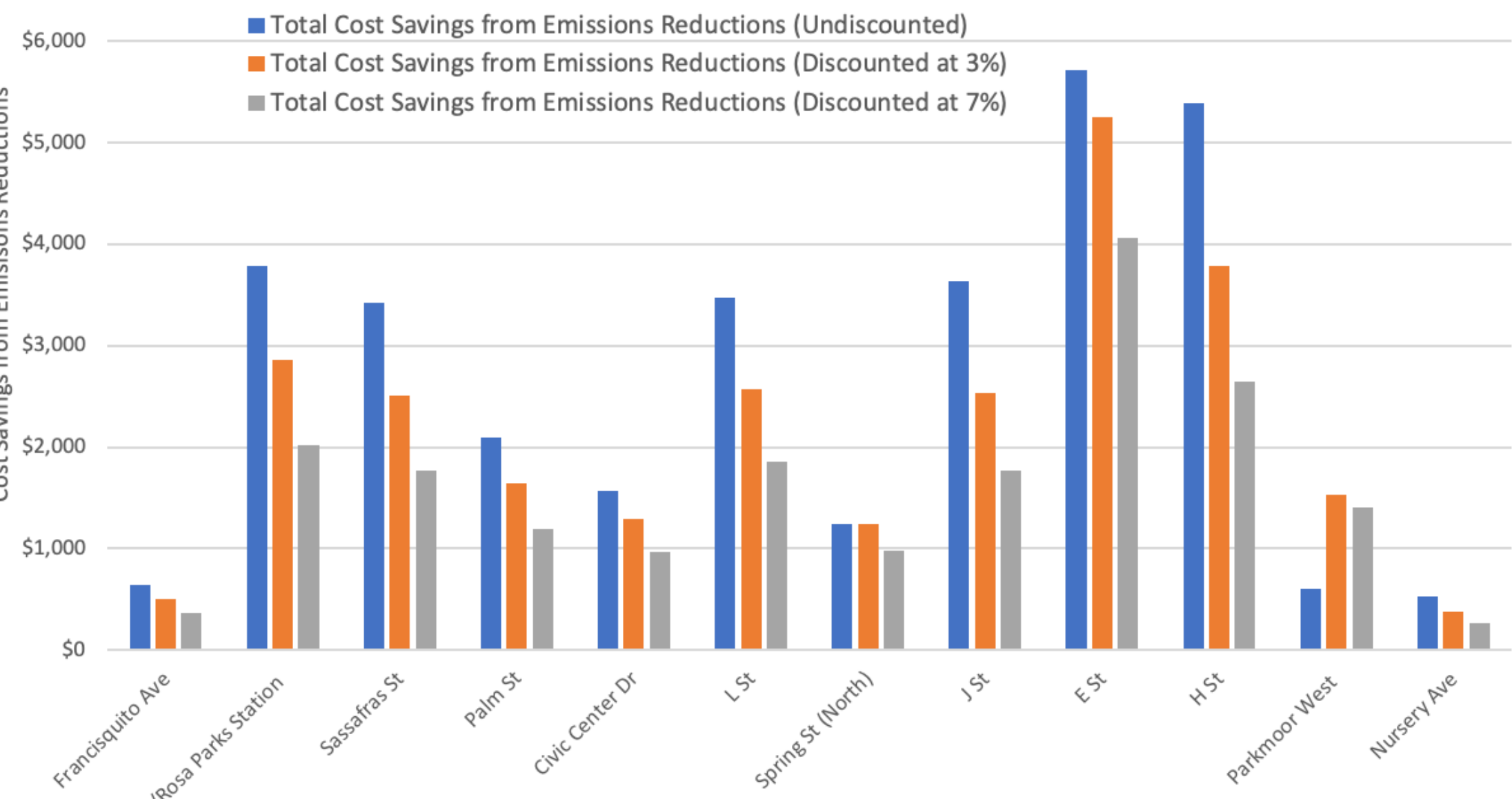

Figure C3. Cost Savings from Emissions Reductions across the Analyzed At-Grade Crossings in California 
Table C4. Total Revenue from Property Taxes (in 2020 dollars) from Properties in a Quarter-Mile Radius

\begin{tabular}{lccc}
\hline \multicolumn{1}{c}{ Roadway Name } & $\begin{array}{c}\text { Total Revenue from } \\
\text { Property Tax } \\
\text { (Undiscounted) }\end{array}$ & $\begin{array}{c}\text { Total Revenue from } \\
\text { Property Tax } \\
\text { (Discounted at 3\%) }\end{array}$ & $\begin{array}{c}\text { Total Revenue from } \\
\text { Property Tax } \\
\text { (Discounted at 7\%) }\end{array}$ \\
\hline $\begin{array}{l}\text { Francisquito Ave. } \\
\text { Willowbrook/Rosa }\end{array}$ & $\$ 60,278,616$ & $\$ 45,296,956$ & $\$ 32,703,978$ \\
Parks Station & $\$ 56,719,999$ & $\$ 42,622,798$ & $\$ 30,773,261$ \\
Sassafras St. & $\$ 46,812,770$ & $\$ 35,177,915$ & \\
Palm St. & $\$ 53,633,650$ & $\$ 40,303,531$ & $\$ 25,398,125$ \\
Civic Center Dr. & $\$ 39,561,099$ & $\$ 29,728,575$ & $\$ 29,098,772$ \\
L St. & $\$ 47,099,965$ & $\$ 35,393,730$ & $\$ 21,463,753$ \\
Spring St. (North) & $\$ 46,740,972$ & $\$ 35,123,961$ & $\$ 25,553,941$ \\
J St. & $\$ 49,397,525$ & $\$ 37,120,253$ & $\$ 25,359,170$ \\
E St. & $\$ 41,356,067$ & $\$ 31,077,421$ & $\$ 26,800,475$ \\
H St. & $\$ 76,393,846$ & $\$ 57,406,904$ & $\$ 22,437,607$ \\
Parkmoor West & $\$ 49,270,401$ & $\$ 37,024,725$ & $\$ 41,447,246$ \\
Nursery Ave. & $\$ 77,615,518$ & $\$ 58,324,941$ & $\$ 26,731,504$ \\
\hline
\end{tabular}


Potential Revenue from Property Taxes (in 2020 USD)

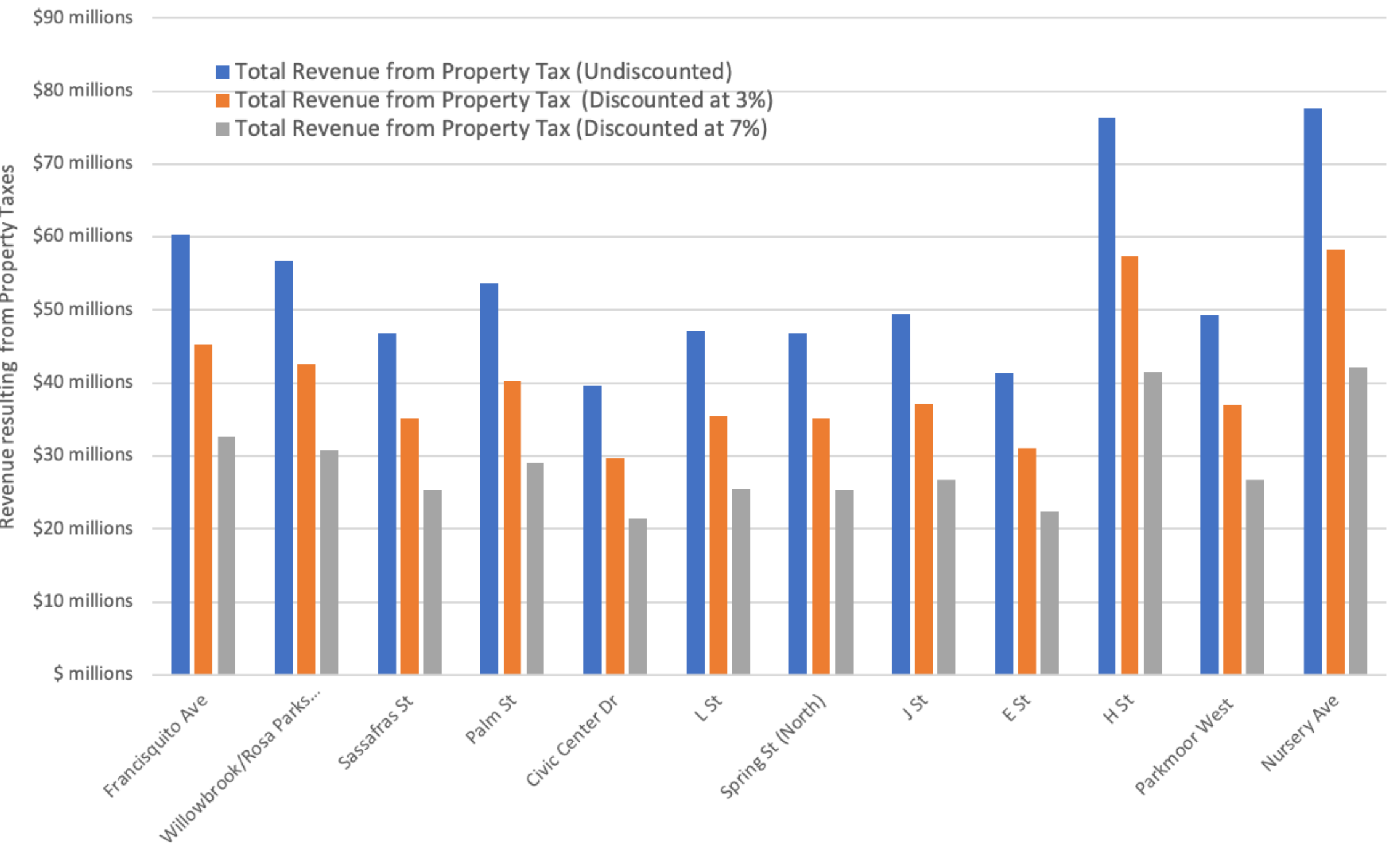

Figure C4. Potential Revenue from Property Taxes from Properties within a Quarter-Mile Radius of the Analyzed At-Grade Crossings in California 
Table C5. Total Benefits from Safety Improvement, Travel Time Savings, Emissions Reductions, and Property Tax Revenue (in 2020 USD)

\begin{tabular}{lccc}
\hline \multicolumn{1}{c}{ Roadway Name } & $\begin{array}{c}\text { Total Benefits } \\
\text { (Undiscounted) }\end{array}$ & $\begin{array}{c}\text { Total Benefits } \\
\text { (Discounted at 3\%) }\end{array}$ & $\begin{array}{c}\text { Total Benefits } \\
\text { (Discounted at 7\%) }\end{array}$ \\
\hline $\begin{array}{l}\text { Francisquito Ave. } \\
\text { Willowbrook/Rosa }\end{array}$ & $\$ 63,268,789$ & $\$ 48,457,930$ & $\$ 35,251,408$ \\
Parks Station & $\$ 58,154,745$ & $\$ 44,067,686$ & $\$ 31,915,948$ \\
Sassafras St. & $\$ 48,672,929$ & $\$ 36,612,522$ & $\$ 26,447,616$ \\
Palm St. & $\$ 61,373,651$ & $\$ 45,837,493$ & $\$ 33,043,058$ \\
Civic Center Dr. & $\$ 41,314,580$ & $\$ 30,998,460$ & $\$ 22,373,468$ \\
L St. & $\$ 53,692,514$ & $\$ 40,104,300$ & $\$ 28,911,083$ \\
Spring St. (North) & $\$ 46,904,083$ & $\$ 35,381,895$ & $\$ 25,583,422$ \\
J St. & $\$ 51,711,916$ & $\$ 38,763,101$ & $\$ 27,967,170$ \\
E St. & $\$ 43,964,080$ & $\$ 33,071,477$ & $\$ 23,893,361$ \\
H St. & $\$ 78,957,988$ & $\$ 59,228,290$ & $\$ 42,739,681$ \\
Parkmoor West & $\$ 49,388,946$ & $\$ 37,234,856$ & $\$ 26,917,226$ \\
Nursery Ave. & $\$ 78,608,770$ & $\$ 59,033,459$ & $\$ 42,614,300$ \\
\hline
\end{tabular}




\section{Total Benefits (in 2020 USD)}

$\$ 90$ millions (safety improvement, travel time savings, emissions reductions and property tax revenue)

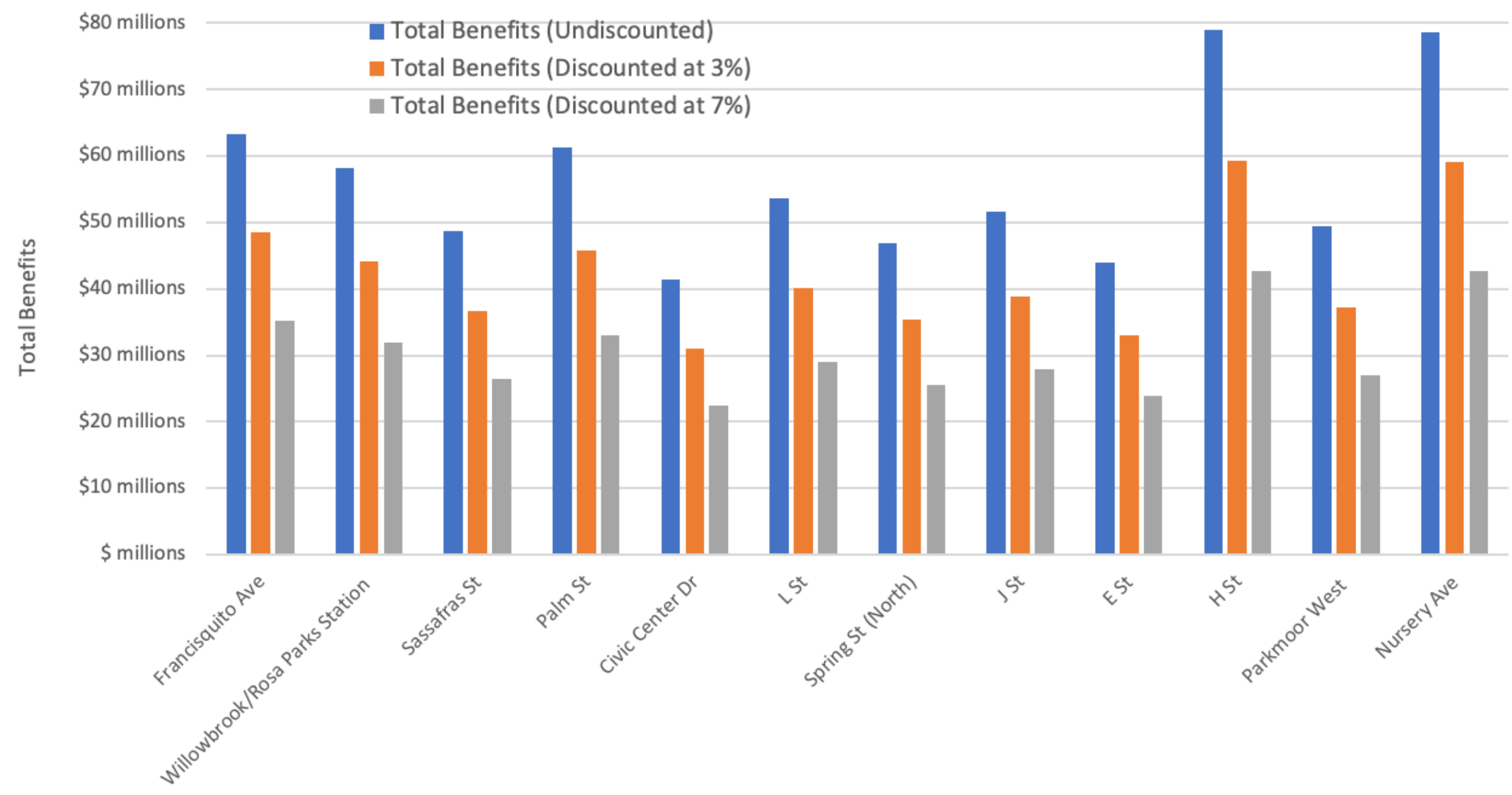

Figure C5. Total Benefits across Safety Improvement, Travel Time Savings, Emissions Reductions, and Property Tax Revenue for the Analyzed At-Grade Crossings in California 
Table C6. Cost of Separation: Undiscounted (in 2020 USD)

\begin{tabular}{lccc}
\hline \multicolumn{1}{c}{ Roadway Name } & $\begin{array}{c}\text { Costs (Undiscounted): } \\
\text { Lower Estimate (in } \\
\text { millions) }\end{array}$ & $\begin{array}{c}\text { Costs (Undiscounted): } \\
\text { Mean Estimate (in millions) }\end{array}$ & $\begin{array}{c}\text { Costs (Undiscounted): } \\
\text { Upper Estimate (in } \\
\text { millions) }\end{array}$ \\
\hline $\begin{array}{l}\text { Francisquito Ave. } \\
\begin{array}{l}\text { Willowbrook/Rosa } \\
\text { Parks Station }\end{array}\end{array}$ S21 $^{\text {Sassafras St. }}$ & $\$ 21$ & $\$ 38$ & $\$ 56$ \\
Palm St. & $\$ 18$ & $\$ 39$ & $\$ 56$ \\
Civic Center Dr. & $\$ 16$ & $\$ 31$ & $\$ 45$ \\
L St. & $\$ 16$ & $\$ 28$ & $\$ 39$ \\
Spring St. (North) & $\$ 20$ & $\$ 29$ & $\$ 41$ \\
J St. & $\$ 16$ & $\$ 37$ & $\$ 54$ \\
E St. & $\$ 20$ & $\$ 28$ & $\$ 39$ \\
H St. & $\$ 24$ & $\$ 38$ & $\$ 55$ \\
Parkmoor West & $\$ 23$ & $\$ 45$ & $\$ 65$ \\
Nursery Ave. & $\$ 16$ & $\$ 44$ & $\$ 64$ \\
\hline
\end{tabular}

Table C7. Cost of Separation: Discounted at 3\% (in 2020 USD)

\begin{tabular}{lccc}
\hline \multicolumn{1}{c}{ Roadway Name } & $\begin{array}{c}\text { Costs } \\
\text { (Discounted at 3\%): } \\
\text { Lower Estimate (in } \\
\text { millions) }\end{array}$ & $\begin{array}{c}\text { Costs } \\
\text { (Discounted at 3\%): } \\
\text { Mean Estimate (in millions) }\end{array}$ & $\begin{array}{c}\text { Costs } \\
\text { (Discounted at 3\%): } \\
\text { Upper Estimate (in } \\
\text { millions) }\end{array}$ \\
\hline $\begin{array}{l}\text { Francisquito Ave. } \\
\begin{array}{l}\text { Willowbrook/Rosa } \\
\text { Parks Station }\end{array}\end{array}$ S20 $_{\text {Sassafras St. }}$ & $\$ 20$ & $\$ 37$ & $\$ 54$ \\
Palm St. & $\$ 17$ & $\$ 37$ & $\$ 55$ \\
Civic Center Dr. & $\$ 15$ & $\$ 31$ & $\$ 44$ \\
L St. & $\$ 16$ & $\$ 27$ & $\$ 38$ \\
Spring St. (North) & $\$ 20$ & $\$ 28$ & $\$ 40$ \\
J St. & $\$ 15$ & $\$ 36$ & $\$ 52$ \\
E St. & $\$ 20$ & $\$ 27$ & $\$ 38$ \\
H St. & $\$ 23$ & $\$ 37$ & $\$ 53$ \\
Parkmoor West & $\$ 22$ & $\$ 43$ & $\$ 64$ \\
Nursery Ave. & $\$ 15$ & $\$ 42$ & $\$ 62$ \\
\hline
\end{tabular}


Table C8. Cost of Separation: Discounted at 7\% (in 2020 USD)

\begin{tabular}{lccc}
\hline \multicolumn{1}{c}{ Roadway Name } & $\begin{array}{c}\text { Costs } \\
\text { (Discounted at 7\%): } \\
\text { Lower Estimate (in } \\
\text { millions) }\end{array}$ & $\begin{array}{c}\text { Costs } \\
\text { (Discounted at 7\%): } \\
\text { Mean Estimate (in millions) }\end{array}$ & $\begin{array}{c}\text { Costs } \\
\text { (Discounted at 7\%): } \\
\text { Upper Estimate (in } \\
\text { millions) }\end{array}$ \\
\hline $\begin{array}{l}\text { Francisquito Ave. } \\
\begin{array}{l}\text { Willowbrook/Rosa } \\
\text { Parks Station }\end{array}\end{array}$ & $\$ 19$ & $\$ 35$ & $\$ 52$ \\
Sassafras St. & $\$ 19$ & $\$ 36$ & $\$ 52$ \\
Palm St. & $\$ 16$ & $\$ 29$ & $\$ 42$ \\
Civic Center Dr. & $\$ 15$ & $\$ 26$ & $\$ 37$ \\
L St. & $\$ 15$ & $\$ 27$ & $\$ 38$ \\
Spring St. (North) & $\$ 19$ & $\$ 35$ & $\$ 50$ \\
J St. & $\$ 15$ & $\$ 26$ & $\$ 37$ \\
E St. & $\$ 19$ & $\$ 35$ & $\$ 51$ \\
H St. & $\$ 22$ & $\$ 41$ & $\$ 61$ \\
Parkmoor West & $\$ 22$ & $\$ 41$ & $\$ 59$ \\
Nursery Ave. & $\$ 15$ & $\$ 25$ & $\$ 36$ \\
\hline
\end{tabular}




\section{Estimated Cost of Grade Separation: Undiscounted (in 2020 USD)}

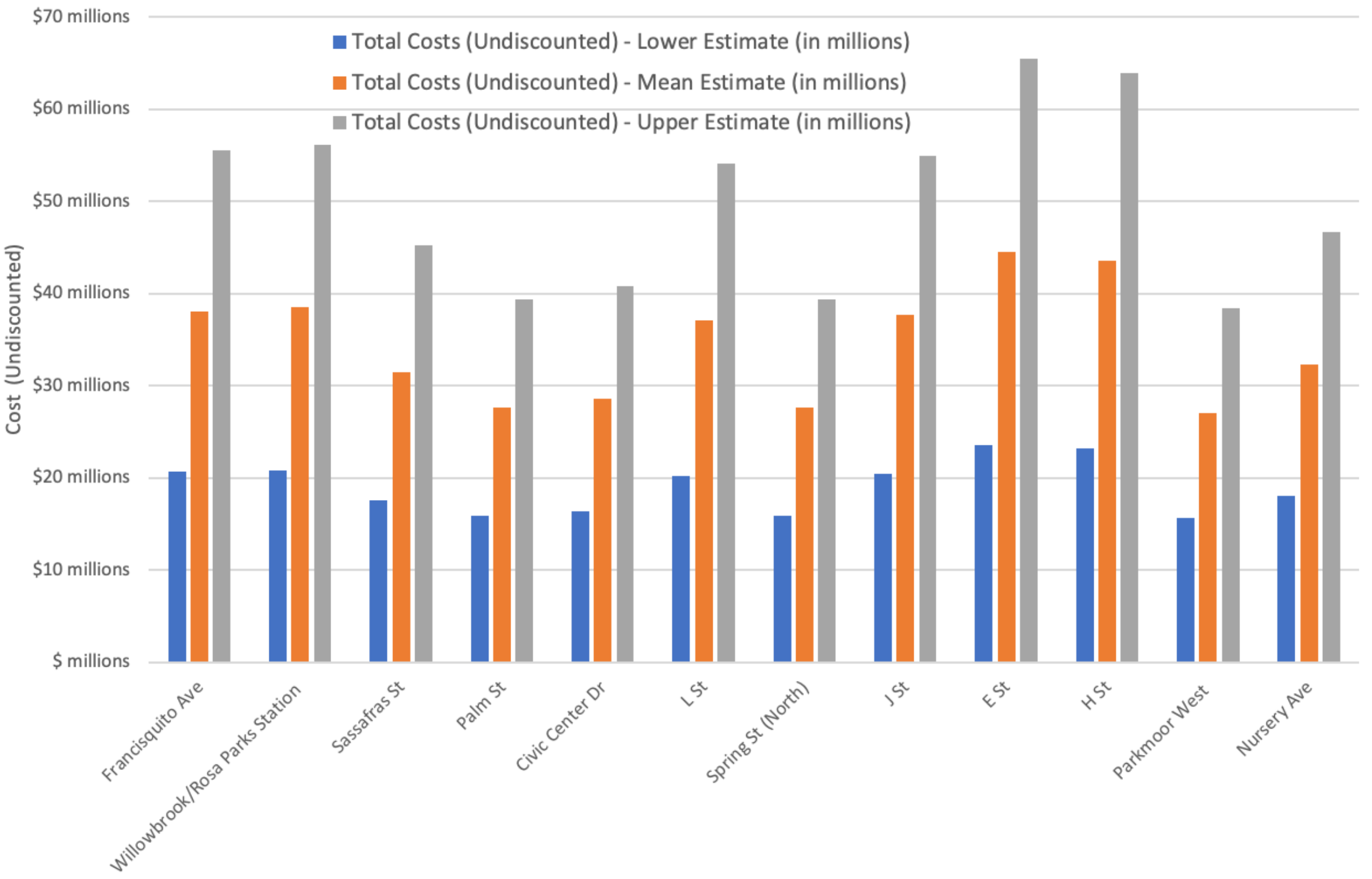

Figure C6. Estimated Undiscounted Cost of Separation for the Analyzed At-Grade Crossings in California 


\section{Estimated Cost of Grade Separation: Discounted at 3\% and 7\% (in 2020 USD)}

\$250 millions - Total Costs (Discounted at 3\%) - Lower Estimate (in millions)

- Total Costs (Discounted at 3\%) - Mean Estimate (in millions)

- Total Costs (Discounted at 3\%) - Upper Estimate (in millions)

- Total Costs (Discounted at 7\%) - Lower Estimate (in millions)

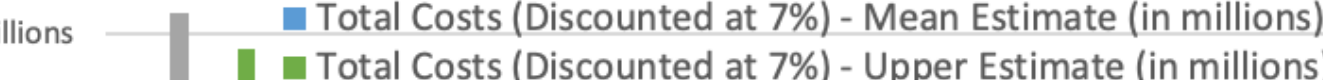

\$150 millions

$\$ 50$ millions

\$ millions

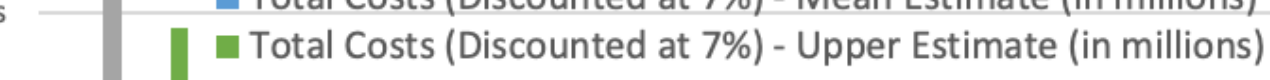

$\begin{array}{cccccc}\text { CAPITOL } & \text { PALOMAR } & \text { CENTRAL } & \text { SWATt } & \text { BASCOM } & \text { EST } \\ \text { MALL } & \text { ST } & \text { EXPWY } & \text { AVENUE } & \text { AVE } & \end{array}$

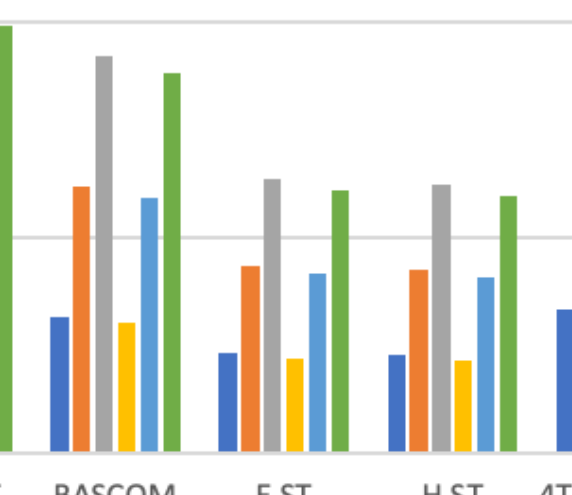

AVE

Figure C7. Estimated Cost of Separation Discounted (at 3\% and 7\%) for the Analyzed At-Grade Crossings in California 
Table C9. Benefits-to-Cost Ratios for All the Combined Benefits Categories (safety, travel time, emissions, and property tax)

\begin{tabular}{|c|c|c|c|c|c|c|c|c|c|}
\hline \multirow{2}{*}{ Roadway Name } & \multicolumn{3}{|c|}{$\begin{array}{c}\text { Benefits-to-Cost Ratio } \\
\text { (Undiscounted) }\end{array}$} & \multicolumn{3}{|c|}{$\begin{array}{l}\text { Benefits-to-Cost Ratio } \\
\text { (Discounted at } 3 \% \text { ) }\end{array}$} & \multicolumn{3}{|c|}{$\begin{array}{l}\text { Benefits-to-Cost Ratio } \\
\text { (Discounted at } 7 \% \text { ) }\end{array}$} \\
\hline & \begin{tabular}{|l|} 
At \\
Lower \\
Cost \\
Estimate
\end{tabular} & $\begin{array}{l}\text { At Mean } \\
\text { Cost } \\
\text { Estimate }\end{array}$ & $\begin{array}{l}\text { At } \\
\text { Upper } \\
\text { Cost } \\
\text { Estimate }\end{array}$ & $\begin{array}{l}\text { At } \\
\text { Lower } \\
\text { Cost } \\
\text { Estimate }\end{array}$ & $\begin{array}{l}\text { At Mean } \\
\text { Cost } \\
\text { Estimate }\end{array}$ & $\begin{array}{l}\text { At } \\
\text { Upper } \\
\text { Cost } \\
\text { Estimate }\end{array}$ & $\begin{array}{l}\text { At } \\
\text { Lower } \\
\text { Cost } \\
\text { Estimate }\end{array}$ & $\begin{array}{l}\text { At Mean } \\
\text { Cost } \\
\text { Estimate }\end{array}$ & $\begin{array}{l}\text { At } \\
\text { Upper } \\
\text { Cost } \\
\text { Estimate }\end{array}$ \\
\hline Francisquito Ave. & 3.1 & 1.7 & 1.1 & 2.4 & 1.3 & 0.9 & 1.8 & 1.0 & 0.7 \\
\hline $\begin{array}{l}\text { Willowbrook/ } \\
\text { Rosa Parks } \\
\text { Station }\end{array}$ & 2.8 & 1.5 & 1.0 & 2.2 & 1.2 & 0.8 & 1.6 & 0.9 & 0.6 \\
\hline Sassafras St. & 2.8 & 1.5 & 1.1 & 2.1 & 1.2 & 0.8 & 1.6 & 0.9 & 0.6 \\
\hline Palm St. & 3.9 & 2.2 & 1.6 & 3.0 & 1.7 & 1.2 & 2.2 & 1.3 & 0.9 \\
\hline Civic Center Dr. & 2.5 & 1.4 & 1.0 & 2.0 & 1.1 & 0.8 & 1.5 & 0.8 & 0.6 \\
\hline L St. & 2.7 & 1.4 & 1.0 & 2.0 & 1.1 & 0.8 & 1.5 & 0.8 & 0.6 \\
\hline Spring St. (North) & 3.0 & 1.7 & 1.2 & 2.3 & 1.3 & 0.9 & 1.7 & 1.0 & 0.7 \\
\hline J St. & 2.5 & 1.4 & 0.9 & 2.0 & 1.1 & 0.7 & 1.5 & 0.8 & 0.5 \\
\hline E St. & 1.9 & 1.0 & 0.7 & 1.4 & 0.8 & 0.5 & 1.1 & 0.6 & 0.4 \\
\hline H St. & 3.4 & 1.8 & 1.2 & 2.6 & 1.4 & 1.0 & 2.0 & 1.1 & 0.7 \\
\hline Parkmoor West & 3.2 & 1.8 & 1.3 & 2.5 & 1.4 & 1.0 & 1.9 & 1.1 & 0.8 \\
\hline Nursery Ave. & 4.4 & 2.4 & 1.7 & 3.4 & 1.9 & 1.3 & 2.5 & 1.4 & 1.0 \\
\hline
\end{tabular}




\section{Benefit-Cost Ratios: All Four Benefits Categories Combined}

5.0 (safety, travel time, emissions, and property tax)

Benefit-cost ratio (Undiscounted) - Lower Cost Estimate Benefit-cost ratio (Undiscounted)-Mean Cost Estimate Benefit-cost ratio (Undiscounted) - Upper Cost Estimate Benefit-cost ratio (Discounted at 3\%) - Lower Cost Estimate - Benefit-cost ratio (Discounted at 3\%) - Mean Cost Estimate - Benefit-cost ratio (Discounted at 3\%) - Upper Cost Estimate - Benefit-cost ratio (Discounted at 7\%) - Lower Cost Estimate - Benefit-cost ratio (Discounted at 7\%) - Mean Cost Estimate - Benefit-cost ratio (Discounted at 7\%) - Upper Cost Estimate

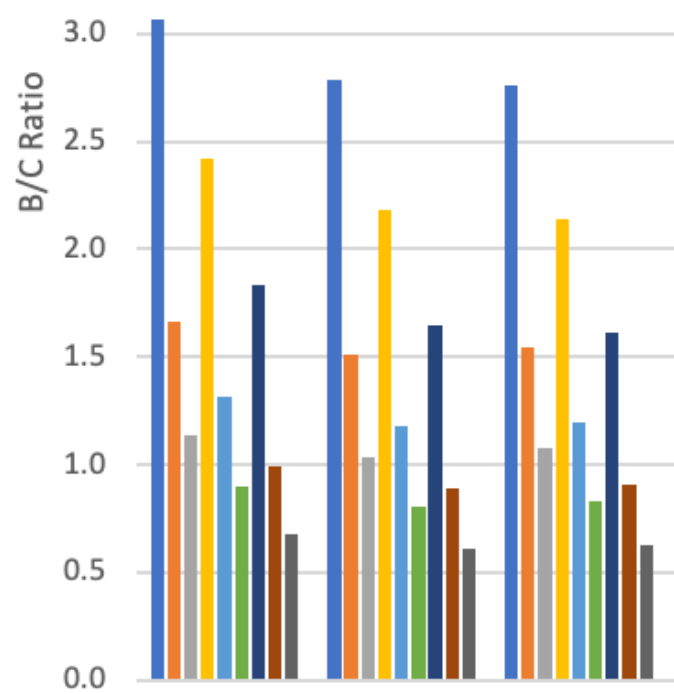

0.0

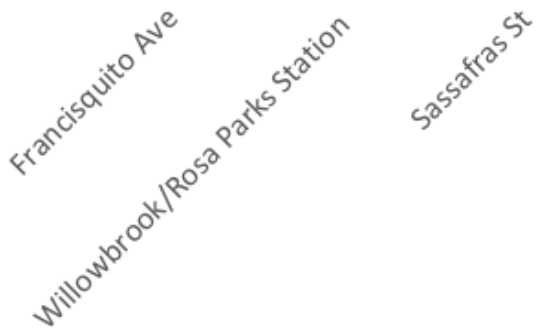

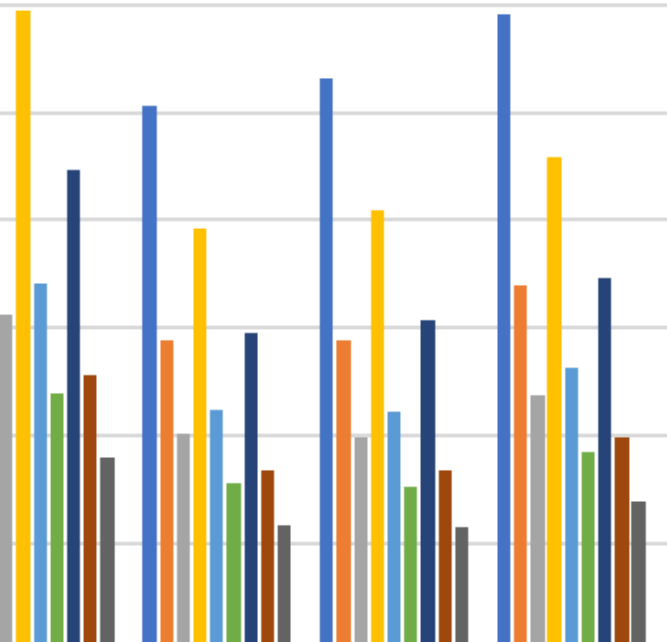<smiles>C1C[C@H]2C[C@H]1C2</smiles><smiles>C[C@H]1C[C@H]1C</smiles>

$5^{x}$

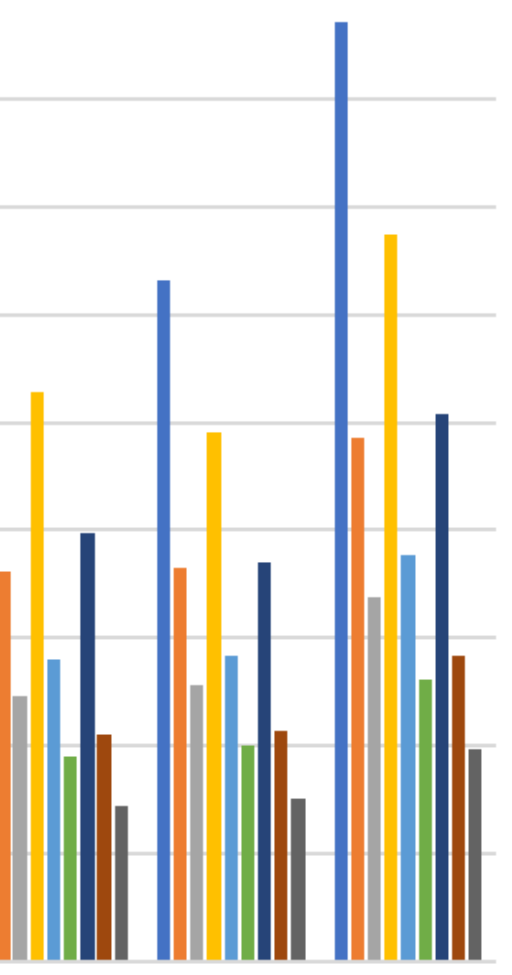

$x^{s^{x}}$
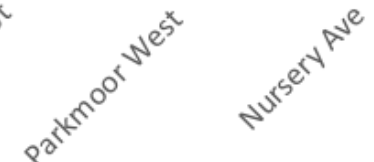

Figure C8. Benefits-to-Cost Ratios for All the Combined Benefits Categories 
Table C10. Benefits-to-Cost Ratios for Just the Property Tax Revenue

\begin{tabular}{|c|c|c|c|c|c|c|c|c|c|}
\hline \multirow{2}{*}{ Roadway Name } & \multicolumn{3}{|c|}{$\begin{array}{c}\text { Benefits-to-Cost Ratio } \\
\text { (Undiscounted) }\end{array}$} & \multicolumn{3}{|c|}{$\begin{array}{c}\text { Benefits-to-Cost Ratio } \\
\text { (Discounted at } 3 \% \text { ) }\end{array}$} & \multicolumn{3}{|c|}{$\begin{array}{c}\text { Benefits-to-Cost Ratio } \\
\text { (Discounted at } 7 \% \text { ) }\end{array}$} \\
\hline & $\begin{array}{l}\text { At } \\
\text { Lower } \\
\text { Cost } \\
\text { Estimate }\end{array}$ & $\begin{array}{l}\text { At Mean } \\
\text { Cost } \\
\text { Estimate }\end{array}$ & $\begin{array}{l}\text { At } \\
\text { Upper } \\
\text { Cost } \\
\text { Estimate }\end{array}$ & $\begin{array}{l}\text { At } \\
\text { Lower } \\
\text { Cost } \\
\text { Estimate }\end{array}$ & $\begin{array}{l}\text { At Mean } \\
\text { Cost } \\
\text { Estimate }\end{array}$ & $\begin{array}{l}\text { At } \\
\text { Upper } \\
\text { Cost } \\
\text { Estimate }\end{array}$ & $\begin{array}{l}\text { At } \\
\text { Lower } \\
\text { Cost } \\
\text { Estimate }\end{array}$ & $\begin{array}{l}\text { At Mean } \\
\text { Cost } \\
\text { Estimate }\end{array}$ & $\begin{array}{l}\text { At } \\
\text { Upper } \\
\text { Cost } \\
\text { Estimate }\end{array}$ \\
\hline Francisquito Ave. & 2.9 & 1.6 & 1.1 & 2.3 & 1.2 & 0.8 & 1.7 & 0.9 & 0.6 \\
\hline $\begin{array}{l}\text { Willowbrook/ } \\
\text { Rosa Parks } \\
\text { Station }\end{array}$ & 2.7 & 1.5 & 1.0 & 2.1 & 1.1 & 0.8 & 1.6 & 0.9 & 0.6 \\
\hline Sassafras St. & 2.7 & 1.5 & 1.0 & 2.1 & 1.2 & 0.8 & 1.5 & 0.9 & 0.6 \\
\hline Palm St. & 3.4 & 1.9 & 1.4 & 2.6 & 1.5 & 1.1 & 2.0 & 1.1 & 0.8 \\
\hline Civic Center Dr. & 2.4 & 1.4 & 1.0 & 1.9 & 1.1 & 0.8 & 1.4 & 0.8 & 0.6 \\
\hline L St. & 2.3 & 1.3 & 0.9 & 1.8 & 1.0 & 0.7 & 1.4 & 0.7 & 0.5 \\
\hline Spring St. (North) & 2.9 & 1.7 & 1.2 & 2.3 & 1.3 & 0.9 & 1.7 & 1.0 & 0.7 \\
\hline J St. & 2.4 & 1.3 & 0.9 & 1.9 & 1.0 & 0.7 & 1.4 & 0.8 & 0.5 \\
\hline E St. & 1.8 & 0.9 & 0.6 & 1.4 & 0.7 & 0.5 & 1.0 & 0.5 & 0.4 \\
\hline H St. & 3.3 & 1.8 & 1.2 & 2.6 & 1.4 & 0.9 & 1.9 & 1.0 & 0.7 \\
\hline Parkmoor West & 3.2 & 1.8 & 1.3 & 2.4 & 1.4 & 1.0 & 1.8 & 1.1 & 0.7 \\
\hline Nursery Ave. & 4.3 & 2.4 & 1.7 & 3.3 & 1.9 & 1.3 & 2.5 & 1.4 & 1.0 \\
\hline
\end{tabular}


Benefit-Cost Ratios: With Property Tax Revenue

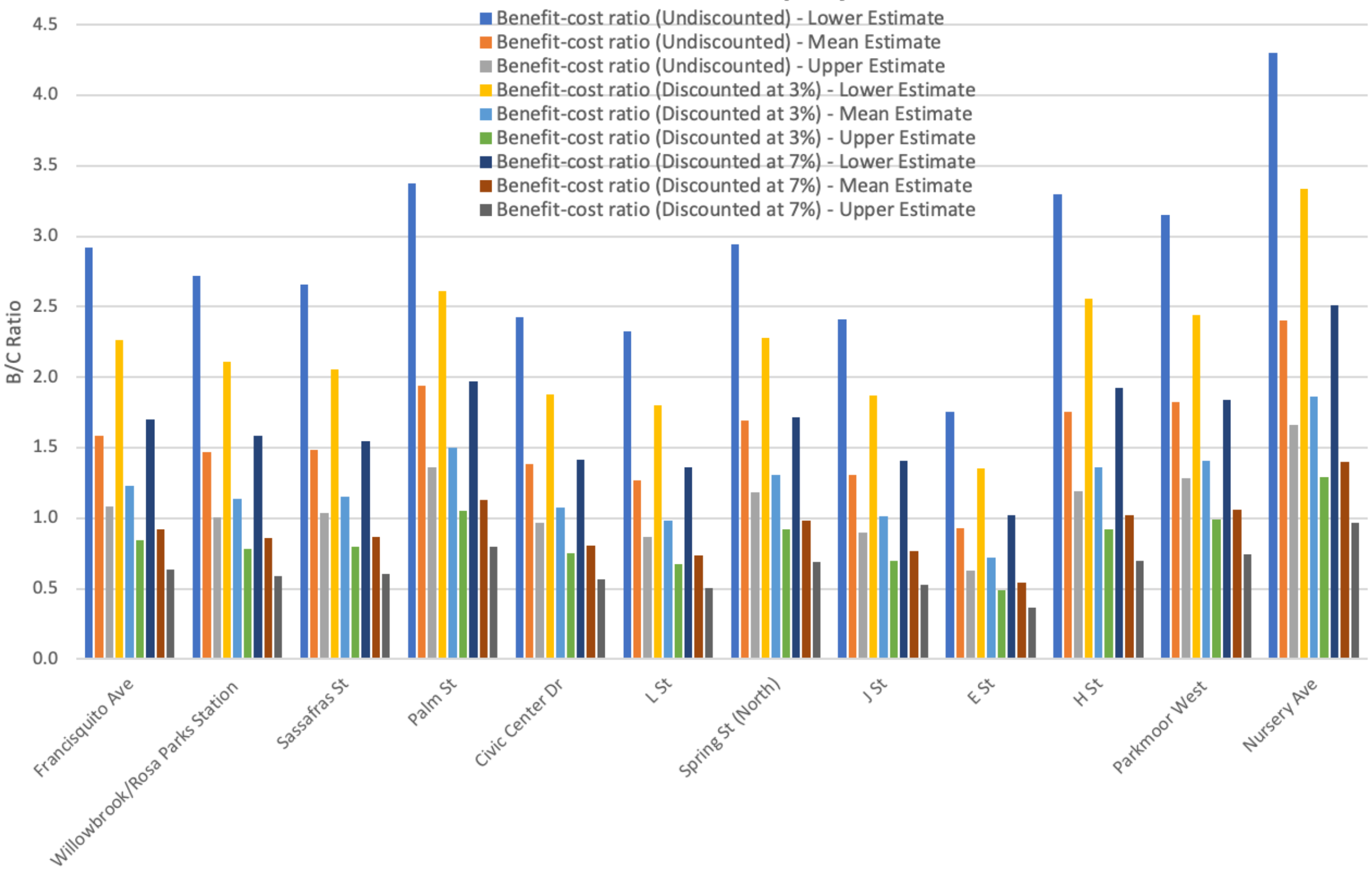

Figure C9. Benefits-to-Cost Ratios for All the Benefits Categories of Property Tax Revenues 
Table C11.Benefits-to-Cost Ratios for the Combined Benefits Categories (safety, travel time, and emissions) EXCEPT Property Tax Revenue

\begin{tabular}{|c|c|c|c|c|c|c|c|c|c|}
\hline \multirow{2}{*}{ Roadway Name } & \multicolumn{3}{|c|}{$\begin{array}{c}\text { Benefits-to-Cost Ratio } \\
\text { (Undiscounted) }\end{array}$} & \multicolumn{3}{|c|}{$\begin{array}{l}\text { Benefits-to-Cost Ratio } \\
\text { (Discounted at } 3 \% \text { ) }\end{array}$} & \multicolumn{3}{|c|}{$\begin{array}{l}\text { Benefits-to-Cost Ratio } \\
\text { (Discounted at } 7 \% \text { ) }\end{array}$} \\
\hline & \begin{tabular}{|l|} 
At \\
Lower \\
Cost \\
Estimate
\end{tabular} & $\begin{array}{l}\text { At Mean } \\
\text { Cost } \\
\text { Estimate }\end{array}$ & $\begin{array}{l}\text { At } \\
\text { Upper } \\
\text { Cost } \\
\text { Estimate }\end{array}$ & $\begin{array}{l}\text { At } \\
\text { Lower } \\
\text { Cost } \\
\text { Estimate }\end{array}$ & $\begin{array}{l}\text { At Mean } \\
\text { Cost } \\
\text { Estimate }\end{array}$ & $\begin{array}{l}\text { At } \\
\text { Upper } \\
\text { Cost } \\
\text { Estimate }\end{array}$ & $\begin{array}{l}\text { At } \\
\text { Lower } \\
\text { Cost } \\
\text { Estimate }\end{array}$ & $\begin{array}{l}\text { At Mean } \\
\text { Cost } \\
\text { Estimate }\end{array}$ & $\begin{array}{l}\text { At } \\
\text { Upper } \\
\text { Cost } \\
\text { Estimate }\end{array}$ \\
\hline Francisquito Ave. & 0.14 & 0.08 & 0.05 & 0.16 & 0.09 & 0.06 & 0.13 & 0.07 & 0.05 \\
\hline $\begin{array}{l}\text { Willowbrook/ } \\
\text { Rosa Parks } \\
\text { Station }\end{array}$ & 0.07 & 0.04 & 0.03 & 0.07 & 0.04 & 0.03 & 0.06 & 0.03 & 0.02 \\
\hline Sassafras St. & 0.11 & 0.06 & 0.04 & 0.08 & 0.05 & 0.03 & 0.06 & 0.04 & 0.02 \\
\hline Palm St. & 0.49 & 0.28 & 0.20 & 0.36 & 0.21 & 0.14 & 0.27 & 0.15 & 0.11 \\
\hline Civic Center Dr. & 0.11 & 0.06 & 0.04 & 0.08 & 0.05 & 0.03 & 0.06 & 0.03 & 0.02 \\
\hline L St. & 0.33 & 0.18 & 0.12 & 0.24 & 0.13 & 0.09 & 0.18 & 0.10 & 0.07 \\
\hline Spring St. (North) & 0.01 & 0.01 & 0.00 & 0.02 & 0.01 & 0.01 & 0.02 & 0.01 & 0.01 \\
\hline J St. & 0.11 & 0.06 & 0.04 & 0.08 & 0.04 & 0.03 & 0.06 & 0.03 & 0.02 \\
\hline E St. & 0.11 & 0.06 & 0.04 & 0.09 & 0.05 & 0.03 & 0.07 & 0.04 & 0.02 \\
\hline H St. & 0.11 & 0.06 & 0.04 & 0.08 & 0.04 & 0.03 & 0.06 & 0.03 & 0.02 \\
\hline Parkmoor West & 0.01 & 0.00 & 0.00 & 0.01 & 0.01 & 0.01 & 0.01 & 0.01 & 0.01 \\
\hline Nursery Ave. & 0.06 & 0.03 & 0.02 & 0.04 & 0.02 & 0.02 & 0.03 & 0.02 & 0.01 \\
\hline
\end{tabular}




\section{Benefit-Cost Ratios: For Three Combined Benefits Categories}

0.60 (safety, travel time, and emissions)

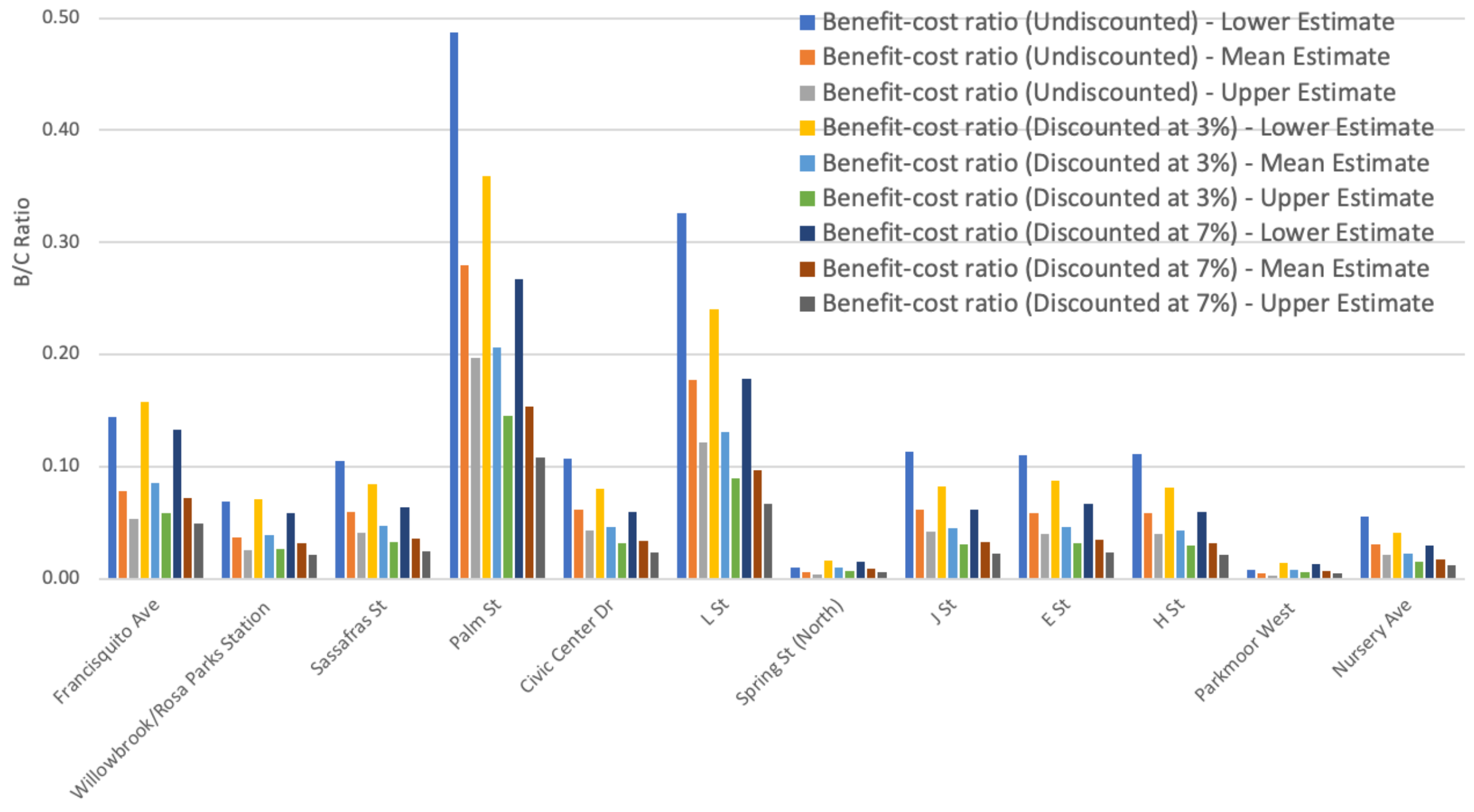

Figure C10.Benefits-to-Cost Ratios for All the Benefits Categories Combined Excluding Property Tax Revenues 


\section{APPENDIX D: UNDERPASS/OVERPASS COST ESTIMATION}

Cost highlights from grade separation prioritization report from Kern County (Kern Council of Governments, 2020):

1. Railroads prefer overpasses to underpasses as they tend to be less disruptive to operations during their construction.

2. Overpasses also tend to be more economical to construct.

3. Key variables in grade separation costs related to the right-of-way acquisition needs, replacement property access needs and those for underpasses utility relocation and hazmat costs.

4. An underpass could be beneficial/needed to avoid clear zone aviation requirements for the airport.

Cost analysis in 2020 USD:

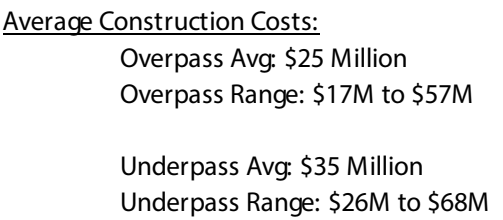

A Rule-of-Thumb Cost Estimate for Future Separations:

a.1) Constructed in a relatively undeveloped area with light traffic: Costs $\$ 17-\$ 19$ Million

a.2) Constructed in a developed area with medium to high traffic: Costs $\$ 23-\$ 29$ Million

I. Overpass Construction Two-Lane (1200ft to $1500 \mathrm{ft}$ )

b) Four-Lane (1200ft to $1300 \mathrm{ft}$

b. 1) Constructed in a relatively undeveloped area with light traffic: Costs $\$ 25-\$ 29$ Million

b.2) Constructed in a developed area with medium to high traffic: Costs $\$ 29-\$ 46$ Million

I. Underpass Construction

b) Four-Lane or Six-Lane: Costs $\$ 40-\$ 60$ Million 


\section{ABBREVIATIONS AND ACRONYMS}

\begin{tabular}{ll}
\hline AADT & Annual Average Daily Traffic \\
BCA & Benefits-to-Cost Analysis \\
CPUC & California Public Utilities Commission \\
FHWA & Federal Highway Administration \\
FRA & Federal Railroad Administration \\
\hline
\end{tabular}




\section{BIBLIOGRAPHY}

Alameda Corridor-East Project. San Gabriel Valley Council of Governments. https://www. theaceproject.org/ (accessed October 12, 2019).

Aldrete, R.M., C.J. Kruse, D. Salgado, S.R. Vadali, A. Mudgal, J.C. Villa, L.E. Cornejo, and D.S. Bae. "Leveraging the Value of Land and Landside Access to Fund Port Infrastructure in Texas." Transportation Research Record 2672, no. 11 (2018): 41-52. https://doi.org/10.1177/0361198118794066

Aldrete, R.M., S. Vadali, D. Salgado, S. Chandra, L. Cornejo, and A. Bujanda. Transportation Reinvestment Zones: Texas Legislative History and Implementation (No. PRC 15-36 F). 2016.

Belzer, D., S. Srivastava, M. Austin, T. Bump, and J. Wood. Transit and Regional Economic Development (No. FTA CA-26-1007-03). 2011.

City of Burlingame. Broadway Grade Separation. https://www.burlingame.org/document center/Public\%20Works/Capital\%20Improvements/Broadway\%20Grade\%20 Sep\%20(82540)/BGS\%20PSR Final January\%2026\%202017.pdf (accessed February 22, 2020).

California Association for Local Economic Development. Primer on California's New Tax Increment Financing Tools. https://www.cacities.org/Resources-Documents/PolicyAdvocacy-Section/Hot-Issues/New-Tax-Increment-Tools/CALED-TIF-Primer-3-17FINAL.aspx (accessed November 21, 2019).

. California Property Tax Calculator. https://smartasset.com/taxes/california-property-taxcalculator\#us/property (accessed February 22, 2020).

California Public Utilities Commission (CPUC). Section 190 Grade Separation Program. https://www.cpuc.ca.gov/uploadedFiles/CPUC Public Website/Content/Safety/ Rail/Rail_Crossings/190GradeSepOverview-v201708.pdf (accessed May 25, 2020).

Caltrans GIS Data. https://gisdata-caltrans.opendata.arcgis.com/datasets/ f71f49fb87b3426e9688fe66039170bc 0 (accessed May 25, 2020).

Cao, X.J., and D. Porter-Nelson. "Real Estate Development in Anticipation of the Green Line Light Rail Transit in St. Paul." Transport Policy 51 (2016): pp.24-32. https:// doi.org/10.1016/j.tranpol.2016.01.007

Cervero, R. Urban Development on Railway-Served Land: Lessons and Opportunities for the Developing World. Berkeley, CA: University of California Berkeley Center for Future Urban Transport, 2009.

Chandra, S., and S. Vadali. "Evaluating Accessibility Impacts of the Proposed America 
2050 High-Speed Rail Corridor for the Appalachian Region." Journal of Transport Geography 37 (2014): 28-46.

https://doi.org/10.1016/j.jtrangeo.2014.04.002

Chen, G., M. Correia, and J. de Abreu e Silva. "Accessibility Indicators for Regional Economic Development: An Application to the Regional Distributive Effects of High-Speed Rail in Spain." 55th Congress of the European Regional Science Association, World Renaissance: Changing Roles for People and Places, August 25-28, 2015, Lisbon, Portugal.

Cidell, J., and B. Alexander. "Spatial Variation among Green Building Certification Categories: Does Place Matter?” Landscape and Urban Planning 91, no. 3 (2009): 142-151. https://doi.org/10.1016/j.landurbplan.2008.12.001

City of Moorhead, Minnesota. SE MAIN AVE/20 ST/21 ST RAILROAD GRADE SEPARATION PROJECT, Project Vital Statistics. (accessed November 1, 2019).

Chicago Region Environmental and Transportation Efficiency Program (CREATE). "CREATE program, partners celebrate opening of 25th Avenue grade separation project." https://www.rtands.com/safety-training/create-program-partnerscelebrate-opening-of-25th-avenue-grade-separation-project/ (accessed October 22, 2019).

Dong, H. "If You Build Rail Transit in Suburbs, Will Development Come?" Journal of the American Planning Association 82, no. 4 (2016): 316-326. https://doi.org/10.1080/01944363.2016.1215258

City of West Sacramento. Enhanced Infrastructure Financing Districts (EIFD). https:// www.cityofwestsacramento.org/business/economic-development/enhancedinfrastructure-financing-districts (accessed November 25, 2019).

Farris, S., and J. Horbas. "Creation vs. Capture: Evaluating the True Costs of Tax Increment Financing." Journal of Property Tax Assessment \& Administration 6, no. 4 (2009): 5-28.

Federal Railroad Administration (FRA). Web Accident Prediction System (WBAPS). https://safetydata.fra.dot.gov/webaps/default.aspx (accessed June 9, 2020).

Giuliano, G. "Land Use Impacts of Transportation Investments: Highway and Transit." In The Geography of Urban Transportation, edited by S. Hanson and G. Giuliano, 237-273. New York: The Guilford Press, 2004.

Gutiérrez, J. "Location, Economic Potential and Daily Accessibility: An Analysis of the Accessibility Impact of the High-Speed Line Madrid-Barcelona-French Border." Journal of Transport Geography 9, no. 4 (2001): 229-242. https://doi.org/10.1016/S0966-6923(01)00017-5 
BayRail Alliance. GRADE SEPARATION. http://www.bayrailalliance.org/grade separation/ (accessed October 29, 2019).

Chicago Region Environmental and Transportation Efficiency Program (CREATE). Grand Avenue \& IHB \& CN Grade Separation. http://www.createprogram.org/factsheets/ GS5a.pdf (accessed November 1, 2019). https://doi.org/10.1061/(ASCE)1076$\underline{0342(2001) 7: 1(1)}$

Hess, D. B., and T.M. Almeida. "Impact of Proximity to Light Rail Rapid Transit on Station-Area Property Values in Buffalo, New York." Urban Studies 44, no. 5-6 (2007): 1041-1068.https://doi.org/10.1080/00420980701256005

Transportation Research Board. Highway Capacity Manual (HCM), 2001. https:// sjnavarro.files.wordpress.com/2008/08/highway capacital manual.pdf (accessed May 26, 2020).

Zillow Research Housing Data. https://www.zillow.com/research/data/ (accessed February 27, 2020).

Kern Council of Governments. GRADE SEPARATION PRIORITIZATION REPORT 2011. http://www.kerncog.org/wp-content/uploads/2017/11/Grade Sep Priority Report. pdf (accessed May 25, 2020).

Ko, K., and X.J. Cao. Impacts of the Hiawatha Light Rail Line on Commercial and Industrial Property Values in Minneapolis. Center for Transportation Studies, University of Minnesota, 2010.

Longitudinal Employer-Household Dynamics (LEHD), Center for Economic Studies, United States Census Bureau. OnTheMap. https://onthemap.ces.census.gov/ (accessed May 30, 2020).

Longitudinal Employer-Household Dynamics (LEHD), Center for Economic Studies, US Census Bureau, OnTheMap Help and Documentation. https://lehd.ces.census. gov/applications/help/onthemap.html\#!what is onthemap (accessed January 22, 2020).

Montana Department of Transportation (MDT). 2016 Montana Rail Grade Separation Study Final Report. https://www.mdt.mt.gov/publications/docs/brochures/MDTRGSS-Final-Report-2016.pdf (accessed May 24, 2020).

Mountain View Voice. https://www.mv-voice.com/news/2018/12/06/study-approved-to-fixrengstorff-train-crossing (accessed on October 28, 2019).

Murakami, J., and R. Cervero. "California High-Speed Rail and Economic Development: Station-Area Market Profiles and Public Policy Responses." University of California, Berkeley Faculty Club, 2010. http://citeseerx.ist.psu.edu/viewdoc/downl oad?doi=10.1.1.232.8492\&rep=rep1\&type=pdf (accessed November 20, 2020) 
O'Sullivan, A. Urban Economics. 8th ed. New York: McGraw-Hill//rwin, 2010.

Primer on California's New Tax Increment Financing Tools, California Association for Local Economic Development. https://www.cacities.org/Resources-Documents/ Policy-Advocacy-Section/Hot-Issues/New-Tax-Increment-Tools/CALED-TIFPrimer-3-17-FINAL.aspx (accessed November 21, 2019).

Caltrans. Proposition 1B - Highway-Railroad Crossing Safety. https://bondaccountability. dot.ca.gov/ProjectListPreAction.do?page=1000026 (accessed May 25, 2020).

Rubin, Thomas A., James E. Moore, and Shin Lee. "Ten Myths about US Urban Rail Systems." Transport Policy 6, no. 1 (1999): 57-73. https://doi.org/10.1016/S0967-070X(98)00032-8

STREETS AND HIGHWAYS CODE (SHC), California Legislative Information. https:// leginfo.legislature.ca.gov/faces/codes displayText.xhtml?lawCode=SHC\&division $=3 . \&$ title $=\&$ part $=\&$ chapter=10.\&article $=($ accessed November 26,2019$)$.

SURFACE TRANSPORTATION BOARD. Appendix K - Transportation Safety and Delay, Northern Rail Extension Draft Environmental Impact Statement, 2020. (accessed May 26, 2020).

Median Property Taxes in California by County. The 2019 Tax Resource. http://www.taxrates.org/california/property-tax\#: :text=The \%20median\%20property $\% 20$ tax $\% 20$ in,as\%20property\%20tax\%20per\%20year (accessed May 24, 2020).

Caltrans. Traffic Volumes. https://dot.ca.gov/programs/traffic-operations/census/trafficvolumes (accessed May 25, 2020).

Texas Department of Transportation (TxDOT). Transportation Reinvestment Zone. https://www.txdot.gov/government/programs/trz.html (accessed November 2, 2019).

US Department of Transportation (USDOT). Revised Departmental Guidance: Valuation of Travel Time in Economic Analysis 2016. https://www.transportation.gov/sites/ dot.gov/files/docs/2016\%20Revised\%20Value\%20of\%20Travel\%20Time $\% 20$ Guidance.pdf (accessed May 23, 2020).

USDOT. 2016 Revised Value of a Statistical Life Guidance. https://www.transportation. gov/sites/dot.gov/files/docs/2016\%20Revised\%20Value\%20of\%20a\%20 Statistical\%20Life\%20Guidance.pdf (accessed May 22, 2020).

USDOT. Benefits-to-Cost Analysis Guidance for Discretionary Grant Programs, June 2018. https://www.transportation.gov/sites/dot.gov/files/docs/mission/officepolicy/transportation-policy/284031/benefits-to-cost-analysis-guidance-2018.pdf (accessed May 31, 2020). 
US Inflation Calculator. https://www.usinflationcalculator.com/page/2/

Vadali, S., R. Aldrete, A. Bujanda, S. Samant, Y. Li, T. Geiselbrecht, B. Kuhn, S. Lyle, K. Dalton, M. Zhang, and S. Tooley. Planning Tools to Assess the Real Estate Leveraging Potential for Roadways and Transit: Technical Report (No. FHWA/TX11/0-6538-1). Texas Transportation Institute, 2011.

Value Capture: Capitalizing on the Value Created by Transportation, FHWA. https://www. fhwa.dot.gov/innovation/everydaycounts/edc 5/value capture.cfm (accessed October 11, 2019).

City of Palo Alto. Funding for Palo Alto Grade Separation and Crossing Improvements by Economic \& Planning Systems, Inc. White paper. https://www.cityofpaloalto.org/ civicax/filebank/documents/64628 (accessed October 17, 2019).

Zandiatashbar, A., S. Hamidi, N. Foster, and K. Park. "The Missing Link between Place and Productivity? The Impact of Transit-Oriented Development on the Knowledge and Creative Economy." Journal of Planning Education and Research 39, no. 4 (2019): 429-441. https://doi.org/10.1177/0739456X19826271

Zhang, M., and B.T. Yen. "The Impact of Bus Rapid Transit (BRT) on Land and Property Values: A Meta-Analysis." Land Use Policy 96 (2020): 104684. https://doi.org/10.1016/j.landusepol.2020.104684

Montana Department of Transportation (MDT), 2016 Montana Rail Grade Separation Study Final Report, "1-Report-2016.pdf." https://www.mdt.mt.gov/publications/ docs/brochures/MDT-RGSS-Final-Report-2016.pdf (accessed April 3, 2020).

Valley Transportation Authority (VTA), 2016 Measure B. https://www.vta.org/projects/ funding/2016-measure-b (accessed November 14, 2019).

Caltrans, 2016 Traffic Volumes on California State Highways. https://dot.ca.gov/-/media/ dot-media/programs/traffic-operations/documents/census/aadt/tc-2016-aadtvolumes-a11y.pdf (accessed May 25, 2020).

Caltrain, 25th Avenue Grade Separation. http://www.caltrain.com/projectsplans/Projects/ Caltrain Capital Program/25th Avenue Grade Separation.html (accessed November 25, 2019). 


\section{ABOUT THE AUTHORS}

\section{SHAILESH CHANDRA}

Dr. Chandra is an associate professor in the Department of Civil Engineering and Construction Engineering Management at California State University, Long Beach (CSULB). He obtained his MS and Ph.D. in civil engineering from Texas A\&M University in 2009 and 2012. Dr. Chandra has more than twelve years of transportation research experience focused on transport connectivity, transportation economics, accessibility, urban freight, and sustainability. He has been a principal investigator $(\mathrm{PI})$ for several projects funded by various transportation agencies, including the California Department of Transportation (Caltrans) and the United States Department of Transportation (USDOT).

\section{MEHRAN RAHMANI}

Dr. Mehran Rahmani is an assistant professor in the Civil Engineering Construction Engineering Management (CECEM) department at California State University, Long Beach. He earned a Ph.D. in Structural and Earthquake Engineering from the University of Southern California (USC) in 2014, an MS in Electrical Engineering (with an emphasis in signal processing) from USC in 2013, and an MS in Structural Engineering from Sharif University of Technology (Iran) in 2009. Before joining CSULB, Dr. Rahmani, a registered Professional Engineer (PE) in California, worked as a Senior Engineer and a Project Engineer in the structural engineering industry from 2014 to 2017.

\section{TIMOTHY THAI}

Mr. Thai is an undergraduate student in the Department of Civil Engineering and Construction Engineering Management at CSULB. His research interests include railroad crossings and real estate analysis.

\section{VIVEK MISHRA}

Mr. Mishra is a graduate student in the Department of Computer Science and Computer Engineering at CSULB. His research interests relate to computer programming and transportation analysis.

\section{JACQUELINE CAMACHO}

Ms. Camacho is an undergraduate student in the Department of Civil Engineering and Construction Engineering Management at CSULB. Her research interests include topics related to crashes at railroad crossings and real estate analysis. 


\section{MTI BOARD OF TRUSTEES}

Founder, Honorable

Norman Mineta*

Secretary (ret.),

US Department of Transportation

\section{Chair,}

Abbas Mohaddes

President \& $\mathrm{COO}$

Econolite Group Inc.

\section{Vice Chair,}

\section{Will Kempton}

Executive Director

Sacramento Transportation Authority

\section{Executive Director,}

Karen Philbrick, PhD*

Mineta Transportation Institute

San José State University

\section{Winsome Bowen}

Chief Regional Transportation

Strategy

Facebook

\section{David Castagnetti}

\section{Co-Founder}

Mehlman Castagnetti

Rosen \& Thomas

\section{Maria Cino}

Vice President

America \& U.S. Government

Relations Hewlett-Packard Enterprise

\author{
Grace Crunican** \\ Owner \\ Crunican LLC
}

\section{Donna DeMartino \\ Managing Director \\ Los Angeles-San Diego-San Luis \\ Obispo Rail Corridor Agency}

\section{Nuria Fernandez**}

General Manager \& CEO

Santa Clara Valley

Transportation Authority (VTA)

\section{John Flaherty}

Senior Fellow

Silicon Valley American

Leadership Form

\section{William Flynn * \\ President \& CEO \\ Amtrak}

\section{Rose Guilbault}

Board Member

Peninsula Corridor

Joint Powers Board

Ian Jefferies*

President \& CEO

Association of American Railroads
Diane Woodend Jones

Principal \& Chair of Board

Lea + Elliott, Inc.

David S. Kim*

Secretary

California State Transportation

Agency (CALSTA)

\section{Therese McMillan}

Executive Director

Metropolitan Transportation

Commission (MTC)

\section{Bradley Mims}

President \& CEO

Conference of Minority

Transportation Officials (COMTO)

Jeff Morales

Managing Principal

InfraStrategies, LLC

Dan Moshavi, PhD*

Dean, Lucas College and

Graduate School of Business

San José State University

Toks Omishakin*

Director

California Department of

Transportation (Caltrans)
Takayoshi Oshima

Chairman \& CEO

Allied Telesis, Inc.

Paul Skoutelas*

President \& CEO

American Public Transportation

Association (APTA)

Beverley Swaim-Staley

President

Union Station Redevelopment

Corporation

Jim Tymon*

Executive Director

American Association of

State Highway and Transportation

Officials (AASHTO)

\section{Larry Willis*}

President

Transportation Trades

Dept.,AFL-CIO

$*$ = Ex-Officio

$* *=$ Past Chair, Board of Trustees

\section{Directors}

\section{Karen Philbrick, PhD}

Executive Director

\section{Hilary Nixon, PhD}

Deputy Executive Director

\section{Asha Weinstein Agrawal, PhD}

\section{Education Director}

National Transportation Finance

Center Director

\section{Brian Michael Jenkins}

National Transportation Security

Center Director

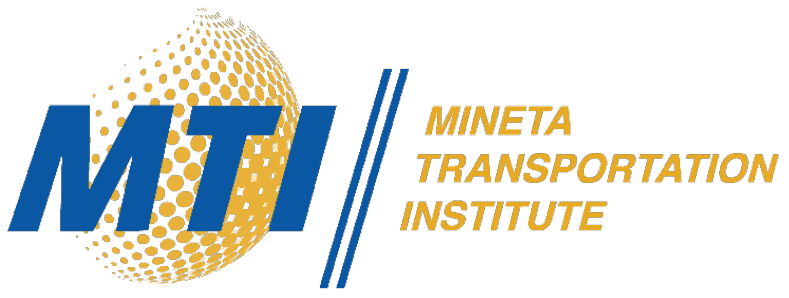

